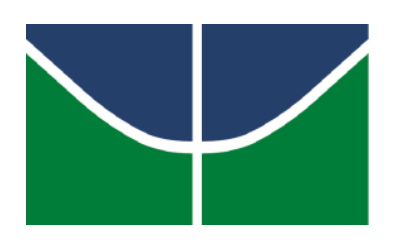

UNIVERSIDADE DE BRASÍLIA

FACULDADE DE EDUCAÇÃO

PROGRAMA DE PÓS-GRADUAÇÃO EM EDUCAÇÃO

MESTRADO EM EDUCAÇÃO

REPRESENTAÇÕES DE PROFESSORES SOBRE O USO DA INFORMÁTICA NA EDUCAÇÃO INFANTIL: ESTUDO DE CASO EM UMA ESCOLA PÚBLICA DE SANTA MARIA (DF) 
DIVA LÚCIA RODRIGUES

\title{
REPRESENTAÇÕES DE PROFESSORES SOBRE O USO DA INFORMÁTICA NA EDUCAÇÃO INFANTIL: ESTUDO DE CASO EM UMA ESCOLA PÚBLICA DE SANTA MARIA (DF)
}

\begin{abstract}
Dissertação de mestrado apresentada ao Programa de Pós-Graduação em Educação, na área de concentração Educação e Tecnologia, e eixo de interesse Educação, Tecnologia e Comunicação Pedagógica da Universidade de Brasília, como requisito parcial à obtenção do título de Mestre em Educação.
\end{abstract}

Orientação: Prof. Dr. Gilberto Lacerda Santos.

Brasília, maio 
Brasília, Maio de 2015.

Ficha catalográfica elaborada automaticamente, com dados fornecidos pela autora

\section{Rodrigues, Diva Lúcia}

Representações de professores sobre o uso da informática na Educação Infantil: Estudo de caso em uma escola pública de Santa Maria (DF) / Diva Lúcia Rodrigues; orientador Gilberto Lacerda Santos - Brasília, 2015.

$105 p$.

Dissertação (Mestrado - Mestrado em Educação) - Universidade de Brasília, 2015.

1. Professores e Informática. 2. Educação Infantil. 3. Representações Docentes. 4. Informática e Educação. 5. Resistência de professores. I. Lacerda Santos, Gilberto, orient. II. Título. 
Diva Lúcia Rodrigues

\section{Representações de Professores sobre o uso da Informática na educação Infantil: Estudo de caso em uma escola pública de Santa Maria (DF)}

Dissertação de Mestrado apresentada ao Programa de Pós Graduação em Educação da Faculdade de Educação da Universidade de Brasília - FE/UNB, como requisito parcial para obtenção do grau de Mestre em Educação, na linha de Pesquisa Informática e Comunicação Pedagógica, aprovada em 29 de Maio de 2015 pela Banca Examinadora constituída pelos professores: Prof. Dr. Gilberto Lacerda Santos (UNB) - Orientador e Coordenador da banca; Profa. Dra. Regina Pina da Silva Neves (Matemática/UNB) - Avaliadora externa e, Profa. Dra. Fernanda Farah Cavaton (UNB) -Avaliadora interna. 
Dedico essa dissertação

A Deus que sempre abençoou os meus passos e me fortaleceu com coragem para questionar realidades e propor sempre um novo mundo de possibilidades.

Ao Fábio, meu marido, pessoa com quem amo partilhar a vida. Com você tenho me sentido mais viva de verdade. Obrigada pelo carinho, pela paciência e por sua capacidade de me trazer paz na correria do dia a dia.

Aos meus amigos, pelas alegrias, tristezas e dores compartilhadas. Com vocês as pausas entre um parágrafo e outro de produção melhora tudo o que tenho produzido na vida. 


\section{AGRADECIMENTOS}

Sou grata a muitas pessoas que se fizeram presentes, de alguma maneira, na elaboração deste trabalho. Assim agradeço:

Ao Prof. Dr. Gilberto Lacerda Santos (Orientador), pelos ensinamentos que me fizeram aperfeiçoar o olhar de pesquisadora, pela orientação sempre tão pontual e proveitosa.

Às professoras que apresentaram contribuições significativas para o enriquecimento deste trabalho, no processo de qualificação: profa. Dra. Maria de Fátima Guerra e a profa. Dra. Fernanda Cavaton.

A minha mais nova amiga, professora Dra. Regina Pina, que sempre trouxe valiosas contribuições nos momentos de conversa e trabalho.

Aos professores do Curso de Mestrado em Educação: profa. Dra. Raquel de Almeida Moraes (UnB), prof. Dr. Gilberto Lacerda Santos (UnB), profa. Dra. Wivvian Weller (UnB), profa. Dra. Claudia Pato (UnB) e prof. Dr. Lúcio Teles (UnB).

Aos colegas do Curso de Mestrado, pelas preciosas amizades, trocas de angústias e expectativas durante o percurso acadêmico.

A todos os meus amigos pelo estímulo e força durante este período de estudos.

À Secretaria de Estado de Educação do Distrito Federal, que me possibilitou tempo para dedicar-me a este trabalho, com o afastamento para estudos.

Às professoras que participaram desta pesquisa, pela disponibilidade e colaboração.

Ao meu marido, Fábio de Souza pela paciência e companheirismo na jornada.

A todos que direta e indiretamente contribuíram e torceram para que eu trilhasse com sucesso esta caminhada. 
Não pode haver qualquer inovação significativa na educação que não tenha como centro as atitudes dos professores, e é uma ilusão pensar de outra maneira.

As crenças, sentimentos e suposições dos professores são o oxigênio de um ambiente de aprendizagem; são eles que determinam a qualidade de vida dentro dele. 


\section{RESUMO}

Esta dissertação estuda as representações de professores sobre o uso da informática na Educação Infantil, por meio de um estudo de caso em uma escola pública de Santa Maria, no Distrito Federal. A investigação fundamenta-se nas concepções de Moscovici (1978); Jodelet (2001) e Alves-Mazzotti (1994) para o entendimento do conceito de representações sociais associadas à educação. $\mathrm{Na}$ análise das representações evidenciadas pelas professoras, o referencial teórico utilizado está baseado no trabalho de autores como: Afonso (1993); Amante (2003); Carneiro (2002); Levy (1999); Santos e Braga (2012); Silva (2010); Venkatesh (2003), entre outros. Com o propósito de compreender, por meio da explicitação de representações de professoras da Educação Infantil, suas concepções e atitudes em relação ao uso da informática nas práticas educativas, foram utilizadas a pesquisa bibliográfica e o estudo de caso, que corroboraram no delineamento das imagens e atitudes frente ao trabalho com a informática na escola. Para o mapeamento das representações das docentes, foram utilizados, no estudo de caso, os seguintes procedimentos: entrevistas, questionários e roda de conversa. Ve-se que a informática está presente em toda a nossa vida. O número de pessoas conectadas aumenta diariamente e, cada vez mais cedo, as crianças são inseridas nessa efervescência digital e tecnológica. Vivemos a era da linguagem digital, na qual aparelhos tecnológicos, sempre mais modernos e com mais funções agregadas, trazem à palma da mão ações que demandariam uma gama de procedimentos e tempo. As escolas não tem ficado para trás. Políticas de inserção de recursos tecnológicos da Educação Infantil ao Ensino Médio são fomentadas em todas as instâncias. A inserção destes recursos informatizados transmite mudanças que são sentidas em todas as áreas, impõe ritmos e dimensões diferentes e inovadoras relacionadas à tarefa de ensinar e aprender. A utilização dos recursos informatizados é vista por pesquisadores como uma promissora área a ser explorada, de modo a favorecer a efetividade do trabalho do professor e ligada ao sucesso da escola. Entretanto, em pleno século XXI docentes sentem-se inseguros, receosos, e envergonhados quando o tema é o uso de recursos informatizados nas atividades pedagógicas com crianças pequenas. O resultado da pesquisa aponta que algumas professoras são resistentes quanto a aceitação e o uso de recursos informatizados na escola, por dificuldades didáticas relacionadas ao desconhecimento da aplicabilidade prática da informática; da falta de experiência no domínio da linguagem digital; e por interpretarem que há uma desconexão com a rotina pedagógica da educação infantil. O maior problema apontado no estudo é a falta de formação continuada, focada no aperfeiçoamento para inserção do recurso como auxílio pedagógico de forma inovadora e articulada ao fazer da educação infantil, isto corrobora na criação de representações distorcidas quanto à aplicação destes na escola. $\mathrm{Na}$ associação de imagens positivas quanto ao uso de recursos informatizados vê-se que o modelo de aceitação e uso de tecnologia UTAUT, fornece indicativos de que a expectativa de desempenho é uma constante na fala das professoras, elas veem a informática como um auxílio para as suas tarefas, mas somente se adequadas à rotina, compatíveis com as habilidades e experiências a serem incentivadas na educação infantil. É importante ressaltar que as professoras pesquisadas estão em busca de formas, individuais ou em grupo, de apropriar-se das funcionalidades pedagógicas dos recursos informatizados para incluí-los na rotina das crianças da educação infantil.

Palavras-chave: Educação Infantil; Professores e Informática; Representações Docentes; Informática e Educação. 


\begin{abstract}
This dissertation studies the representations of teachers on the use of information technology in early childhood education, by means of a case study in a public school of Santa Maria, in the Federal District. The investigation is based on conceptions of Moscovici (1978); Jodelet (2001) and Adam-Mazzotti (1994) to the understanding of the concept of social representations associated with education. In the analysis of representations highlighted by teachers, the theoretical framework used is based on the work of authors such as: Afonso (1993); Lover (2003); Lamb (2002); Levy (1999); Santos and Braga (2012); Silva (2010); Venkatesh (2003), among others. With the purpose to understand, through explicit representations of teachers of early childhood education, their concepts and attitudes regarding the use of information technology in educational practices, were used the bibliographical research and case study, which corroborate the delineation of the images and attitudes front to work with computers at school. The number of people connected increases daily and increasingly early, children are inserted in this digital and technological effervescence. We live in the era of digital language, in which technological devices, more modern and more aggregate functions, bring the Palm of the hand actions that would demand a range of procedures and time. The schools don't have fallen behind. Insertion policies of technological resources of early childhood education to high school are encouraged in all instances. The insertion of these computerized channel resources changes that are felt in all areas, impose rhythms and different and innovative dimensions related to the task of teaching and learning. The use of computerized resources is seen by researchers as a promising area to be explored, in order to promote the effectiveness of the work of professor and linked to the success of the school. However, in the 21 st century teachers feel insecure, afraid, and embarrassed when the topic is the use of computer resources in educational activities with young children. The search result shows that some teachers are resistant as the acceptance and use of computerized resources at school, educational difficulties related to lack of knowledge about the practical applicability of information technology; the lack of experience in the field of digital language; and interpret that there is a disconnect with the pedagogical routine of early childhood education. The biggest problem pointed to the study is the lack of continuing training, focused on perfecting for insertion of the resource as a pedagogical aid in an innovative way and articulate in making of early childhood education, this supports the creation of distorted representations about the application of these in school. In the positive images about the use of computerized resources to see if that model of acceptance and use of UTAUT technology, provides indications that the expectation of performance is a constant in the speech of the teachers, they see computers as an aid to your tasks, but only if suitable for routine, consistent with the skills and experience to be encouraged in early childhood education. It is important to note that the teachers surveyed are in search of ways, individual or in a group, to take ownership of the pedagogical features of computerized resources to include them in the routine of the children of early childhood education.
\end{abstract}

Key words: early childhood education; Teachers and Computers; Teaching Representations; Computers and education. 


\section{LISTA DE FIGURAS}

Figura 1 - Teoria unificada de Aceitação e Uso de Tecnologia UTAUT ............................ 52

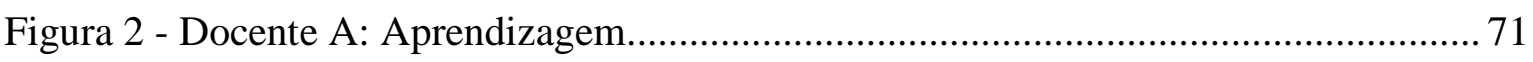

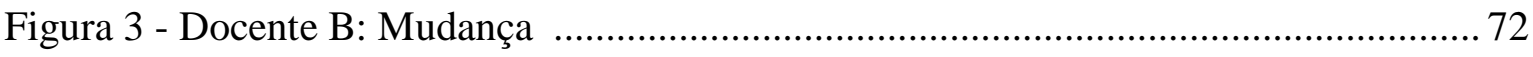

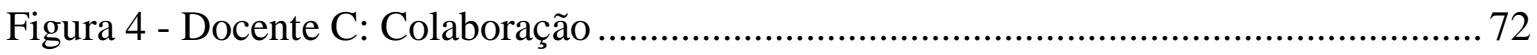

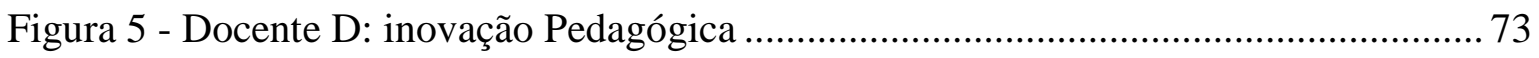

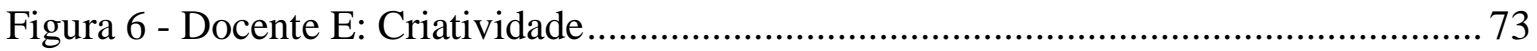

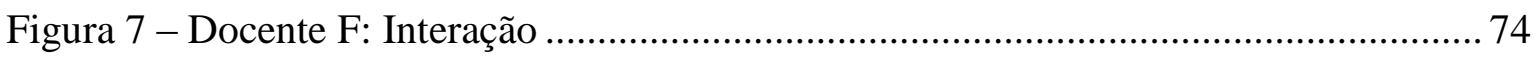

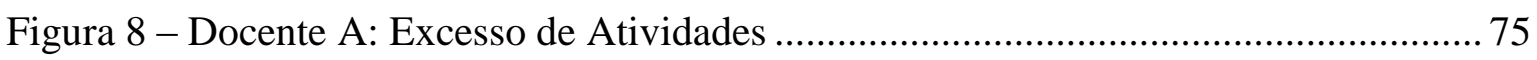

Figura 9 - Docente B: Receio de Ser substituído pela tecnologia ..................................... 76

Figura 10 - Docente C: Dificuldade em entender a Tecnologia ........................................... 77

Figura 11- Docente D: Falta de tempo na preparação das atividades em conhecer as

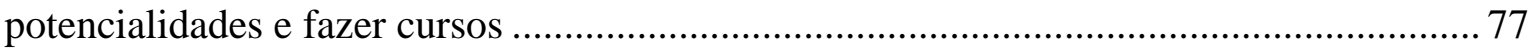

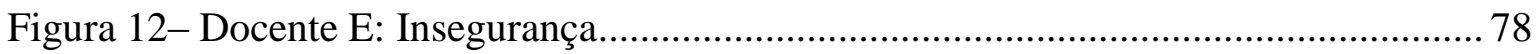

Figura 13 - Docente F: Vergonha de não estar incluído no mundo Digital ........................ 79

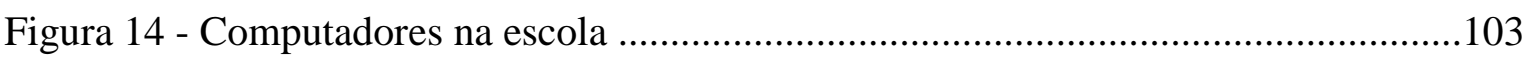

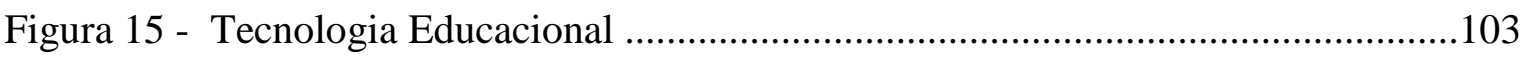

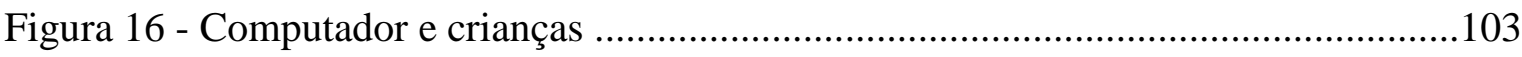

Figura 17 - Professores e Computadores ........................................................................104

Figura 18 - Impacto das Tecnologias no dia a dia ............................................................ 104

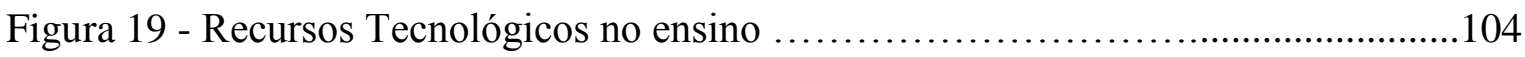

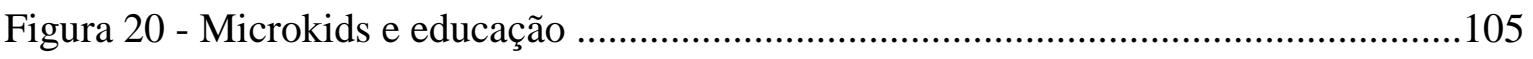

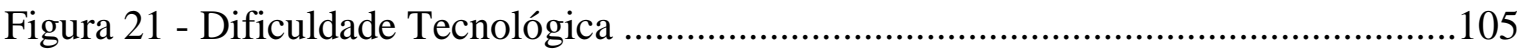

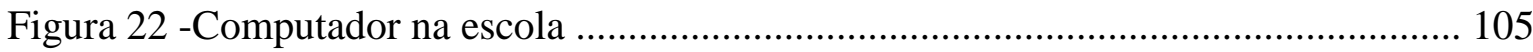




\section{SUMÁRIO}

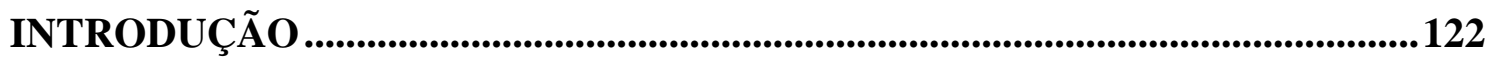

1 TECNOLOGIA E EDUCAÇÃO ....................................................................188

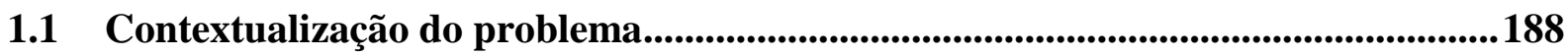

1.2 Tecendo o Problema de pesquisa ...................................................................244

2 A EDUCAÇÃO INFANTIL E AS TECNOLOGIAS DIGITAIS DE COMUNICAÇÃO E EXPRESSÃO ..............................................................................299

2.1 O uso da Informática na educação Infantil - Modalidades e Pressupostos ...........377

2.1.1 Modalidades de uso da Informática na educação Infantil ..........................................377

2.1.2 Pressupostos de uso da informática na Educação Infantil.......................................388

2.1.3 Relatos experiências de uso de recursos tecnológicos na Educação Infantil ............. 41

3 O ESTUDO DAS REPRESENTAÇÕES DE PROFESSORES SOBRE A INFORMÁTICA NA EDUCAÇÃO INFANTIL ...........................................................443

4 MODELO TEÓRICO SOBRE ACEITAÇÃO E USO DE TECNOLOGIA (

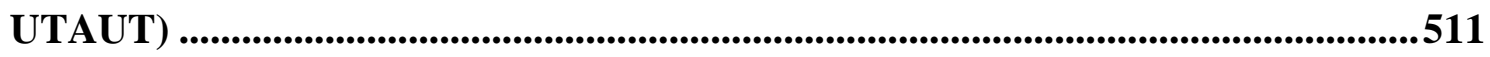

5 METODOLOGIA DA PESQUISA ..................................................................................555

5.1 Abordagem Metodológica ...........................................................................................................566

5.2 Instrumentos e procedimentos para a construção de dados ..................................566

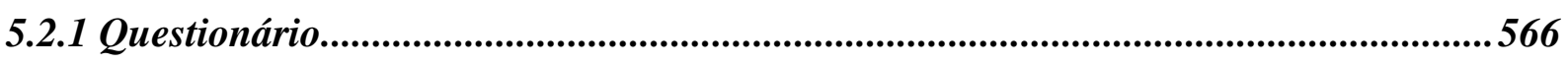

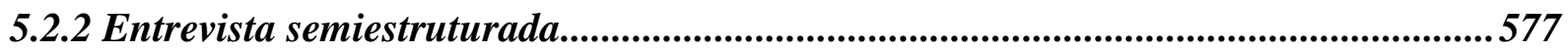

5.2.3 Roda de Conversa ................................................................................................................58

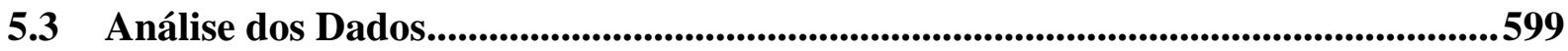

6 AS PROFESSORAS PESQUISADAS E A TECNOLOGIA DIGITAL ...............600

7 ELUCIDANDO AS REPRESENTAÇÕES DAS PROFESSORAS SOBRE O USO DA INFORMÁTICA COM CRIANÇAS PEQUENAS.......................................677

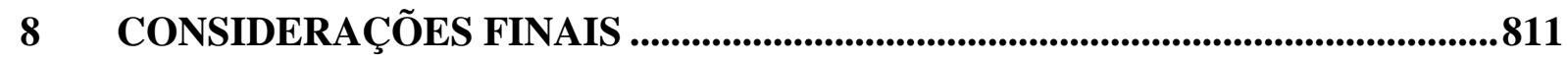

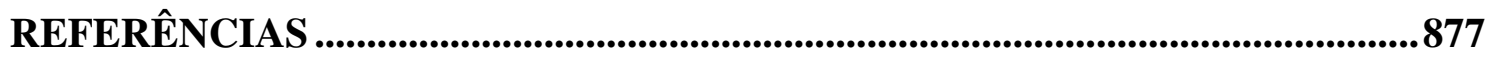
APÊNDICES...................................................ERRO! INDICADOR NÃO DEFINIDO.8 


\section{INTRODUÇÃO}

A informática está presente em toda a nossa vida. O número de pessoas conectadas aumenta diariamente e, cada vez mais cedo, as crianças são inseridas nessa efervescência digital e tecnológica. Pesquisas apontam que estamos na era da linguagem digital, na qual aparelhos tecnológicos, sempre mais modernos e com mais funções agregadas, trazem à palma da mão ações que demandariam uma gama de procedimentos e tempo.

As escolas não tem ficado para trás. Políticas de inserção de recursos tecnológicos da Educação infantil ao ensino médio e de ampliação das instituições educacionais atendidas são fomentadas em todas as instâncias sociais. Algumas dessas políticas são implantadas com a justificativa de inserir e capacitar o estudante para o mundo que ora se apresenta, para que ele possa construir o seu conhecimento e ressignificá-lo com o auxílio da linguagem digital.

A inserção de recursos informatizados transmite mudanças que são sentidas em todas as áreas. Na educação, impõe ritmos e dimensões diferentes e inovadoras relacionadas à tarefa de ensinar e aprender. A utilização dos recursos informatizados é vista por pesquisadores como uma promissora área a ser explorada, de modo a favorecer a efetividade do trabalho do professor e ligada ao sucesso da escola. Entretanto, demanda do professor uma permanente aprendizagem e adaptação constante da prática pedagógica às novidades trazidas pela sociedade do conhecimento. Moran, Masetto e Behrens (2000) apontam que todo o conhecimento está ligado e depende de um contexto cultural, social e histórico, podendo estes modificá-lo ou reformulá-lo. Esse contexto também atua colaborando na formação das representações construídas.

A introdução dos recursos tecnológicos trouxe uma série de indagações para a área educacional quanto ao papel do professor, da educação e da importância do uso da informática para auxílio do estudante e do professor. Indagações sobre o melhor uso, seus ganhos e as perdas integram o consciente de professores que compõem as escolas de todos os níveis e modalidades.

Contudo, com a implantação dos recursos nas escolas, questões didáticas referentes à integração da informática surgiram e permeiam as relações escolares. Vê-se que tem aumentado o número de máquinas informatizadas, mas pouco se vê de efetiva mudança nas práticas pedagógicas de ensino usadas por professores. Tem-se um aparato tecnológico que pouco acrescentou aos processos didáticos ou inovou, mas vê-se a perpetuação de práticas ultrapassadas ou a transposição da lógica da sala de aula para a lógica de uso das tecnologias. 
Martinez (2004) afirma que a maioria dos professores em serviço não tem conhecimento sobre como se utilizam as ferramentas tecnológicas ou quais as possibilidades pode integrar a sua sala de aula. Para entender isto, vê-se que há a necessidade de uma emergente formação continuada para o conhecimento das possibilidades e o incentivo ao uso das tecnologias. Contudo, programas de formação continuada, como o ProInfo Integrado, têm procurado sanar essas dificuldades, mas infelizmente não são relatados resultados notáveis. Quando juntamos dados referentes ao número de docentes que frequentaram o curso do início ao fim e que atuam na educação infantil, vê-se que há um grande número de abandono das turmas de formação.

O quadro geral referente à inserção da informática na educação infantil, considerando os recursos existentes na coordenação de ensino de Santa Maria, mostra que as escolas de educação infantil estão equipadas com laboratório de informática e internet wifi, contudo a efetividade de uso didático é inexistente. Têm-se iniciativas isoladas de uso da informática, entretanto nenhuma atende prioritariamente a premissa de inserção de uma inovação, do aperfeiçoamento de processos educativos traduzidos em potencialidades pedagógicas.

Percebe-se que o professor entende a emergência de incorporação da informática nos processos escolares. Porém, vislumbra-se um processo de resistência, num estágio de não aceitação da informática como inovação pedagógica. A tão anunciada facilitação do trabalho e praticidade não apareceu, têm-se agora concepções e atitudes incorporadas pelo grupo de professores que inibem a adoção da informática enquanto recurso tecnológico facilitador.

A observação desta temática, com o enfoque nas relações didáticas na educação infantil, decorre da atuação como vice-diretora em uma escola que atende crianças pequenas ocasião em que presenciei um aumento da preocupação quanto à expansão e qualidade do atendimento a crianças pequenas. Governos, organizações internacionais (OIs) e organizações da sociedade civil (OSCs) apresentaram resultados de avaliações que apontaram a educação e o cuidado na primeira infância como itens prioritários para a construção de uma sociedade mais digna. Neste sentido, observou-se um fomento de políticas públicas voltadas para a inserção de recursos diversos naquela etapa de ensino, entre os quais, a informática educativa. No entanto, constatou-se, com o decorrer do tempo, que a inserção da informática na Educação Infantil, não necessariamente, provocava mudanças ou inovações na prática pedagógica dos colegas de trabalho da autora.

A euforia característica da possibilidade de inovação iniciou-se em 2008, quando a Secretaria de Educação do Distrito Federal (SEDF) realizou um levantamento sobre a disponibilidade de espaço nas escolas de Educação Infantil para a implantação de laboratórios 
de informática, considerando aspectos, tais como: acesso à banda larga, equipamentos e a manutenção destes. Passou-se a pensar na possibilidade de se concretizar um laboratório de informática funcionando com todos os equipamentos necessários. Em 2009, no início das aulas, as primeiras escolas receberam computadores, impressoras e projetores, mas deveriam aguardar os técnicos que fariam a instalação e deixar as caixas fechadas, ou perderiam a garantia. Resultado: aguardaram durante todo o ano. $\mathrm{O}$ olhar para as caixas aumentava a euforia em uns e alimentava o pessimismo de outros que não vislumbravam inovação ou mudança em um aglomerado de caixas.

Com a política de descentralização dos recursos financeiros, proposta pela política de governo em 2010, algumas escolas utilizaram parte do dinheiro para contratar técnicos especializados em manutenção e providenciaram melhorias na rede elétrica, colocando os equipamentos para funcionar. Desde então, o número de laboratórios na Educação Infantil tem aumentado, recursos financeiros têm sido disponibilizados para equipar e funcionar as máquinas e, até mesmo, equipamentos foram comprados e distribuídos para as escolas. Entretanto, identificou-se outro dilema: como utilizar os equipamentos com os alunos, uma vez que muitos professores não sabiam operá-los?

Entraram em cena os Núcleos de Tecnologia Educacional (NTE), com a finalidade de incluir digitalmente os professores e assessorar as escolas no uso dos equipamentos oferecendo formação continuada aos profissionais docentes. Contudo, a formação continuada ali oferecida ainda não contemplava os docentes que atuavam na Educação Infantil, seja por dificuldades advindas da formação acadêmica ou pela inexistência de profissionais nas escolas para motivarem e planejarem com os professores, modalidades de uso que possam integrar os recursos à prática pedagógica em tal nível de ensino, respeitando e agregando novas possibilidades à Educação.

Nos anos subsequentes, a euforia inicial foi substituída pela desmotivação advinda da emergência de conflitos em relação ao uso da informática na Educação. Os professores passaram a demonstrar inquietação e incerteza quanto ao uso de recursos informatizados, tendo em vista os problemas que foram surgindo e a ausência de soluções adequadas. Com base nas ideias de Afonso (1993), existem fatores capazes de influenciar na formação de representações negativas, que determinam os comportamentos dos sujeitos, os quais não dependem apenas das características objetivas da situação, mas da representação que se constroem da referida situação (AFONSO, 1993, apud Abric, 1998, Abric, 1989, pag. 189).

Atualmente, a situação é bastante complexa, devido à existência de escolas de Educação Infantil com grande quantidade de recursos informatizados, laboratórios com equipamentos 
novos, monitores para auxílio do professor, mas tudo totalmente inoperante e sem integrar a rotina da educação infantil, sem atuar na melhoria da prática pedagógica e sem auxiliar o ensino e a aprendizagem das crianças, devido a problemas relacionados à aceitação e ao uso da informática pelas docentes.

A opção metodológica de estudo das representações sociais das professoras tem sua base fundamentada por estudos teóricos de Moscovici (1978), Jodelet (2001) e AlvesMazzotti (1994) que identificam as representações como uma maneira de um grupo pensar e interpretar a realidade cotidiana, uma forma de conhecimento dos pensamentos e atitudes de determinados indivíduos que compõem uma esfera de relacionamentos.

Segundo Abric (1998):

A representação permite criar um sistema de interpretação da realidade, regendo as relações entre os indivíduos, tanto como o seu meio físico quanto social, determinando, inclusive as práticas e comportamentos, sendo, portanto uma visão global e unitária que "reestrutura a realidade para permitir a integração das características objetivas do objeto". (ABRIC, 1998, p. 27-28).

Partindo dessa interpretação que as representações influenciam a aceitação e adoção de determinado recurso informatizado e considerando as experiências vividas enquanto dirigi a escola, intentei compreender, por meio da explicitação das representações de docentes da escola pública de Educação Infantil, suas concepções e atitudes com relação ao uso da informática na prática educativa. Com o intuito de atender o objetivo exposto acima, planejou-se especificamente: investigar como as docentes interpretam a inserção da informática na escola de Educação Infantil; e identificar, por meio de rodas de conversa, as concepções e atitudes das professoras referentes ao uso da informática com crianças pequenas.

Segundo o Ministério da Educação, 81,9\% dos professores da educação básica brasileira são do sexo feminino. Na educação infantil este número se eleva para 96,6\%, portanto neste estudo de caso não foi diferente, as participantes atuavam como professoras de um Centro de Educação Infantil, nos anos de 2013 a 2014. Situada na região administrativa de Santa Maria, Distrito Federal (DF), a escola está bem aparelhada tecnologicamente e possui em seu corpo docente professoras comexperiência na atuação com crianças pequenas. No primeiro capítulo, a pesquisa traz uma revisão teórica sobre a temática da tecnologia e a educação, para realizar a contextualização do problema. Nele se apresenta um histórico sobre a inserção de recursos informatizados na educação, os principais programas e projetos pensados no mundo e 
implantados no Brasil com a finalidade de trazer essas inovações da linguagem digital ao trabalho pedagógico.

A fim de aprofundar o entendimento teórico da construção das representações, o segundo capítulo, lança luz sobre os estudos que tratam da ampliação e implantação da Educação Infantil como política educativa para crianças pequenas e o uso das tecnologias digitas de comunicação e expressão nesta modalidade. Sua fundamentação teórica está baseada em documentos como: a Constituição Federal (1988), que trata a educação como um direito subjetivo, a Lei de Diretrizes e Bases da Educação, o Estatuto da Criança e do Adolescente (1990), as Diretrizes Curriculares da Educação Infantil (2012) e o Currículo da Educação em Movimento da Secretaria de Estado de Educação do Distrito Federal (2013) para a Educação Infantil.

No terceiro capítulo, tem-se um aprofundamento maior no estudo das representações das professoras sobre a informática na educação infantil, partindo da conceituação do que é representação social de Moscovici (1978), bem como o entendimento de como estas representações atuam na formação de concepções e atitudes frente às crenças de um grupo social. Os textos organizados por Cerqueira (2012) oferecem uma luz frente à temática no estudo das relações educativas que estão emaranhadas de sentido social. Santos e Braga (2012) contribuem com a apresentação de algumas representações equivocadas que atuam na aceitação e no uso da tecnologia.

No quarto capítulo, apresenta-se o modelo teórico sobre aceitação e uso de tecnologia (UTAUT- Unified Theory of Acceptance and Use of Technology), criado a partir do construto de oito distintos modelos de aceitação de tecnologia com a finalidade de unificar os principais estudos sobre o tema. A pesquisa e interpretação deste arquétipo nos leva a conhecer e refletir sobre fatores que atuam como motivação para a quebra de resistências quanto ao aceite e ao uso da informática no trabalho com crianças pequenas.

No quinto capítulo, apresenta-se a metodologia da pesquisa. A abordagem metodológica é a de um estudo de caso (YIN, 2005), que parte de um contexto real, uma escola de educação infantil que possui recursos informatizados e professoras que convivem com o desafio de inseri-los na rotina das crianças pequenas. Para a construção dos dados, foi utilizado o questionário, a entrevista semiestruturada e a roda de conversa, que tiveram seu foco em identificar as representações docentes frente às perguntas construídas com o porte teórico.

No sexto capítulo, tem-se um perfil da escola e das professoras que participaram da pesquisa e a tecnologia digital, suas crenças de como as utilizam em casa e na escola, sua formação para a atuação com a informática, suas dificuldades de ordem didática e 
tecnológica, o desconhecimento de possibilidade de adequação à prática. Reflete-se sobre como ela trata estas questões e como estas são decisivas na construção das representações que determinam a adoção de qualquer recurso tecnológico.

No capítulo sete, com base na roda de conversa e na entrevista, apresenta-se uma elucidação das principais representações das professoras sobre o uso da informática com crianças pequenas na escola pesquisada. Partindo do entendimento de qual pressuposto que justificava a inserção dos recursos na escola e da compreensão das modalidades de uso da informática (AFONSO,1993), podem-se interpretar como estes construtos atuam na formação da atitude em usar ou não o recurso. A ausência de uma efetiva formação é apontada como um dos fatores para a resistência. Neste capítulo, verifica-se o poder das imagens na construção das representações associadas às palavras que definem sua atitude frente à possibilidade de uso.

No capítulo oito, são apresentadas proposições que nos levam a refletir sobre as representações identificadas e investigar o modo como estas atuam na construção do conceito de possibilidade positiva e negativa para inovação na educação. Têm-se apontamentos que sinalizam para uma possibilidade de aceitação, mas que precisam posteriormente ser testados e comprovados a luz de um aprofundamento na leitura e na experimentação. 


\section{TECNOLOGIA E EDUCAÇÃO}

\subsection{Contextualização do problema}

O número de pessoas conectadas, em todo o mundo, aumenta diariamente e, entre estas, encontram-se as crianças que, cada vez mais cedo, têm acesso a recursos tecnológicos e digitais. Esses recursos, por sua vez, também vêm avançando e ganhando espaço no mundo, minuto a minuto. Pesquisa do Instituto Brasileiro de Geografia e Estatística (IBGE), do ano de 2012, destaca o computador como um dos itens mais presentes nas residências dos brasileiros. Em 2012, havia quase 83,4 milhões de internautas, sendo o Brasil o quinto país mais conectado do mundo.

Segundo a Agência Brasil de Comunicação, uma pesquisa realizada pelo comitê Gestor da Internet no Brasil (CGI.br), no ano de 2013, aponta que cerca de 62\% dos alunos das escolas públicas do país tem computador em casa. Um quadro comparativo do avanço do computador nas residências e escolas brasileiras nos mostra que esse número tem aumentado todos os anos. A reportagem afirma, ainda, que o número de alunos com acesso ao computador é crescente desde 2010, primeiro ano do levantamento, quando o percentual era 54\%. Em 2013, essa proporção entre estudantes da rede pública já tinha avançado para 56\%.

No âmbito educacional, a escola tem inovado buscando estratégias para integrar os recursos tecnológicos às suas necessidades pedagógicas, desde a educação infantil até o ensino superior. A primeira iniciativa de uso de recursos informatizados no ensino, em território brasileiro, tem suas origens históricas na década de 1970, quando, pela primeira vez, em 1971, se discutiu o uso de computadores para o ensino de Física, em um seminário promovido pela Universidade Federal de São Carlos (UFSCar), com a participação de um especialista da Universidade de Dartmouth dos EUA (Estados Unidos da América).

Em 1973, algumas experiências com uso de computadores começaram a ser desenvolvidas em outras universidades, como, por exemplo: na Universidade Federal do Rio de Janeiro (UFRJ), os computadores passaram a ser utilizados como recurso auxiliar do professor para ensino e avaliação de simulações em Química; e na Universidade Federal do Rio Grande do Sul (UFRGS), os computadores tornaram-se ferramenta para o desenvolvimento de softwares educativos para o ensino.

Entre as pesquisas que procuravam auxiliar a inserção de recursos tecnológicos no ensino, destacam-se: as experiências do Laboratório de Estudos Cognitivos do Instituto de Psicologia - LEC, na Universidade Federal do Rio Grande do Sul, no ano de 1970, as quais 
eram apoiadas nas teorias de Piaget e Papert, tendo por público-alvo crianças com dificuldades de aprendizagem de leitura, escrita e cálculo.

$\mathrm{Na}$ educação infantil, a primeira iniciativa de destaque foi desenvolvida por Seymour Papert, um educador matemático que, nos anos sessenta, no MIT - Massachusetts Institute of Technology, de Cambridge, MA, Estados Unidos, investigou o uso de computadores com linguagem LOGO para trabalhar com crianças e adolescentes. Essa experiência foi adaptada para o português em 1982, na Unicamp, pelo Núcleo de Informática aplicada à Educação (NIED). Segundo Papert, “o computador pode concretizar e personalizar o formal e sendo bem utilizado permite abordar de forma concreta os conhecimentos, até então somente acessíveis via processos formais" (PAPERT, 1985, p.173 ).

Na década de 1980, as tentativas para que a escola pudesse inovar em sua rotina com a inserção de recursos informatizados não paravam. Foram lançadas ações governamentais como estratégia para o desenvolvimento tecnológico, com vistas a fomentar o desenvolvimento da microeletrônica, bem como preparar profissionais com competências científico tecnológica para atuar nos setores produtivos. Tal iniciativa representou uma inovação ao criar um espaço de diálogo com pesquisadores e educadores que se dedicavam a estudos sobre computadores e educação, bem como viabilizou a articulação entre pesquisa, ensino e extensão, elemento chave das atividades da área. Tem-se o destaque para os seminários realizados pela Universidade Estadual de Campinas (Unicamp) em conjunto com o Ministério da Educação, a Secretaria Especial de Informática, e a comunidade científica, com a finalidade de debater ideias de como implantar projetos-piloto sobre uso dos computadores para ensino e aprendizagem nas universidades.

Após pesquisas realizadas e aprofundadas, com a finalidade de criar referências para uma adequada utilização da informática, antecedendo sua disseminação massiva, foi implantado pelo Ministério da Educação, em 1984, o primeiro programa de informática na educação do Brasil, denominado Projeto EDUCOM - Educação com Computador. Ele promoveu a criação de centros-piloto em cinco universidades públicas brasileiras: Universidade Federal do Rio Grande do Sul (UFRGS), Universidade Federal do Rio de Janeiro (UFRJ), Universidade Federal de Pernambuco (UFPE), Universidade Federal de Minas Gerais (UFMG) e na Universidade Estadual de Campinas (Unicamp), com a finalidade de realizar pesquisa multidisciplinar e capacitar recursos humanos para subsidiar a decisão de informatização da educação pública brasileira. Tais centros apresentaram resultados em relação à produção de software educativo, aplicação experimental desses softwares em 
escolas públicas, mediante o uso do computador como ferramenta para o desenvolvimento de projetos (ANDRADE; LIMA, 1993).

O Projeto EDUCOM ocorreu durante 5 (cinco) anos (de 1984 a 1989) e, nesse período, os resultados do Projeto fizeram com que o MEC criasse, em 1986, o Programa de Ação Imediata em Informática na Educação de $1^{\circ}$ e $2^{\circ}$ graus, destinado a capacitar professores (Projeto FORMAR) e a implantar infraestruturas de suporte nas secretarias estaduais de educação (Centros de Informática Aplicada à Educação de $1^{\circ}$ e $2^{\circ}$ graus - Cied), nas escolas técnicas federais (Centros de Informática na Educação Tecnológica - Ciet) e nas universidades (Centro de Informática na Educação Superior - Cies). O projeto FORMAR consistia em cursos de especialização em nível de pós-graduação lato sensu, com 360h ou mais, por meio do qual os professores eram preparados para atuar nesses centros como multiplicadores na formação de outros professores, mediante a oferta de cursos de informática na educação.

Em 1989, o MEC instituiu o primeiro Programa Nacional de Informática Educativa PRONINFE, com a finalidade de desenvolver ações de capacitação de professores e técnicos, implantar centros de informática na educação, apoiar a aquisição de equipamentos computacionais e a produção, aquisição, adaptação e avaliação de software educativo. Este Programa foi impulsionado pela ideia de mudança pedagógica fundamentada na abordagem educacional construcionista (PAPERT, 1985; VALENTE, 1999) e na educação transformadora freiriana (FREIRE, 2001; ALMEIDA, 2005), segundo as quais a construção do conhecimento deve ser baseada na realização de algo concreto, decorrente de uma experiência conjugada à prática pedagógica crítico-reflexiva vinculada à realidade da escola e à finalidade de formar cidadãos que se percebem como sujeitos de sua história, comprometidos com a construção de uma sociedade mais justa e igualitária. Havia a expectativa de superar a abordagem educacional baseada na transmissão de informações, no entanto, as práticas inovadoras não se sustentavam diante das dificuldades enfrentadas pelos professores para dar prosseguimento ao trabalho com projetos interdisciplinares até chegar à sistematização do conhecimento produzido (ALMEIDA, 2008).

Apesar insucesso das tentativas, a mobilização para a inovação, com a inserção de recursos informatizados na escola, não parou. Em 1996, o Governo do Brasil criou, no MEC, a Secretaria de Educação a Distância - SEED, com a finalidade de fomentar a incorporação das TIC à educação e atuar no desenvolvimento da educação a distância, com vistas à democratização do acesso e melhoria de qualidade da educação. A SEED impulsionou a criação de programas com foco na introdução de tecnologias na escola e na preparação do 
professor, desenvolvidos em cooperação com as secretarias de educação, responsáveis por articular as diretrizes dos programas com as políticas estaduais e municipais e conduzir o processo de inserção das TIC nos Núcleos de Tecnologia Educacional - NTE e nas escolas públicas (ALMEIDA, 2008).

Em 1996, foi criado o Programa TV Escola e, em 1997, o Programa Nacional de Informática na Educação - ProInfo. Posteriormente, outros programas foram criados pelo MEC (Rádio Escola, DVD Escola, Rede Interativa Virtual de Educação - RIVED, entre outros), cada um deles direcionado à incorporação de determinada tecnologia e à preparação dos educadores para sua utilização na escola (ALMEIDA, 2008).

O Programa Nacional de Informática na Educação (ProInfo) foi pensado com a perspectiva de promover o uso pedagógico de Tecnologias de Informação e Comunicações (TIC) na rede pública de ensino Fundamental e Médio. No período de execução do programa, dados do Sistema de Avaliação da Educação Básica (Saeb) e do Censo Escolar mostravam a necessidade de implementação de laboratórios de informática nas escolas de áreas rurais e urbanas e que a falta de infraestrutura, como a internet, causava a subutilização dos equipamentos, bem como a necessidade de ampliação da formação docente para utilização das tecnologias com o enfoque pedagógico.

A fim de propiciar a integração entre mídias, linguagens e tecnologias na prática pedagógica, a SEED/MEC criou, no ano de 2005, o programa Mídias na Educação (MEC/SEED, 2006) de formação continuada de professores, na modalidade de educação a distância. Esse programa era voltado para a "formação de um leitor crítico e criativo, capaz de produzir e estimular a produção nas diversas mídias” (NEVES; MEDEIROS, 2006).

Em 2007, após dez anos de criação, o programa ganhou uma nova versão e passou a ser denominado de Programa Nacional de Tecnologia Educacional - ProInfo. Desde então, os Municípios e/ou Estados e o Distrito Federal passaram a se responsabilizar pela disponibilização da infraestrutura necessária para o funcionamento dos equipamentos; pelo incentivo à capacitação de professores e outros agentes educacionais para utilização pedagógica das tecnologias da informação e comunicação. Além disso, passaram a se responsabilizar, também, por prover as condições necessárias ao trabalho da equipe de apoio para o desenvolvimento e acompanhamento das ações de capacitação nas escolas e, assim que findasse o prazo de garantia dos equipamentos pela empresa contratada, o município se responsabilizaria pelo suporte técnico e pela manutenção dos equipamentos.

As iniciativas de fomentar a inclusão digital não se restringiram à criação do ProInfo. Também no ano de 2007, foi criado um projeto denominado Um Computador por Aluno 
(UCA), que foi iniciado com o objetivo de intensificar a inserção das tecnologias da informação e da comunicação (TIC) nas escolas, por meio da distribuição de computadores portáteis aos alunos da rede pública de ensino. Para tanto, foram selecionadas cinco escolas em que se realizaram experimentos iniciais em uma fase pré-piloto, nas cidades de São Paulo, Porto Alegre, Palmas, Piraí e Brasília. Esse projeto aspirava complementar as ações do Ministério da Educação referente a universalização de acesso à tecnologia e a informação, a partir da meta de garantir a todas as crianças e a todos os professores o direito ao seu próprio computador e a tecnologias na educação, defendendo a expansão do acesso dos estudantes e professores, bem como a produção e disponibilização de mídias educacionais para a aprendizagem com o foco no uso pedagógico da informática.

O projeto passou por dificuldades em relação à licitação e a própria estrutura das Unidades escolares, pois muitas não possuíam espaço e muito menos acesso a rede de internet para seu uso. Desse modo, ele foi concretizado em 2008, após a implantação do Programa Banda Larga nas Escolas (PBLE), realizada pelo governo federal, como parte do Plano Geral de Metas para a Universalização do Serviço Telefônico Fixo Comutado Prestado no Regime Público (PGMU). O programa propunha o atendimento de todas as escolas públicas urbanas de nível fundamental e médio, participantes dos programas E-Tec Brasil, além de instituições públicas de apoio à formação de professores: Polos da Universidade Aberta do Brasil, Núcleo de Tecnologia Estadual (NTE) e Núcleo de Tecnologia Municipal (NTM).

Em 2010, com o objetivo de promover a inserção digital e o desenvolvimento dos processos de ensino e aprendizagem de alunos e professores das escolas públicas brasileiras, com foco na integração entre a tecnologia e o currículo, mediante a utilização de laptops educacionais, foi criado o Programa um computador por aluno (PROUCA). O programa foi implantado em 227 municípios e o objetivou capacitar 6.650 professores. Entre as avaliações encontradas da implantação do programa, destaca-se que ele foi bem além de transformação da cultura pedagógica, pois viabilizou a diminuição da evasão escolar e aproximação do ambiente da sala de aula de uma nova linguagem, a linguagem digital, que propõe a redefinição do papel do professor. Ele passa a ser mais um orientador do que um especialista. $\mathrm{Na}$ avaliação de pesquisadores, o PROUCA promoveu mudanças no dia a dia da sala de aula de professores e alunos, pois, a partir do pressuposto que o computador poderia ser uma ferramenta para ampliar os processos de ensino e aprendizagem, a Internet entrou na sala de aula para ampliar as possibilidades de acessibilidade ao conhecimento e renovar as possibilidades de apropriação do conhecimento pelos novos meios de comunicação digital. (EGLER; COSTA, 2010) 
Com a perspectiva de que a inovação ou a mudança na educação se processa através da integração de recursos tecnológicos com o currículo da escola do século XXI, no livro Projeto Um Computador por Aluno: Pesquisas e perspectivas, os autores Almeida, Barreto e Jesus (2012) defendem que:

As TIC podem ter um papel catalisador na educação, há um empenho político no sentido de promover a inserção do laptop nas escolas públicas, superando o uso instrumental e representando uma nova experiência de educação e de integração social, mais próxima da cultura tecnológica do século XXI. Assim, o uso do laptop na escola pode favorecer o despertar da curiosidade intelectual dos alunos ao desafiá-los a se conectarem com o mundo num diálogo entre ideias e culturas e a provocar a religação do currículo com o cotidiano. A mudança e a inovação se concretizam na medida em que a escola se abre ao mundo. (ALMEIDA; BARRETO; JESUS, 2012, p. 264)

Com o avanço das tecnologias, nos anos de 2012 a 2013, aparelhos portáteis (tablet's) foram sendo introduzidos na escola. Essa ação tinha como propósito garantir as condições de acesso às tecnologias de informação e comunicação nos contextos social, acadêmico e escolar aos professores e estudantes das escolas públicas do país. Para tanto, o Ministério da Educação disponibilizou, através do Programa Nacional de Tecnologia Educacional (ProInfo Integrado), por meio do FNDE, o tablet educacional, como uma ferramenta capaz de facilitar a visualização de conteúdos, estimular atividades cooperativas e o desenvolvimento de projetos e, assim, contribuir para a realização de diversas atividades pedagógicas. Desse modo, o equipamento propiciava o acesso aos seguintes conteúdos: Portal do Professor / MEC; Portal Domínio Público; Khan Academy (Física / Matemática / Biologia / Química): tradução para português com parceria da Fundação Lemann; Projetos de Aprendizagem Educacionais (Banco Internacional de Objetos Educacionais - MEC); Coleção Educadores.

Entretanto, mesmo as iniciativas e pesquisas sobre a inserção de recursos informatizados na escola, em pleno século XXI, o mundo virtual ainda é algo que amedronta muitos professores. Essa foi a conclusão do Instituto Oi Futuro, após a pesquisa encomendada pela Secretaria Municipal de Educação (SME) do Rio de Janeiro, com professores do $5^{\circ}$ ao $9^{\circ}$ ano do Ensino Fundamental de escolas públicas. A referida pesquisa revelou o percentual de $53 \%$ de docentes que possuem dificuldades em lidar com a informática para fins pedagógicos (JORNAL DA CIÊNCIA, 2011). Ela aponta uma generalizada falta de formação para a utilização dos equipamentos, bem como a ausência efetiva de programas de capacitação que dêem conta das demandas escolares em relação à informática educativa.

Vê-se um fervilhar tecnológico que pouco acrescentou à qualidade da educação. Segundo a psicóloga Afira Ripper(1995), professora da UNICAMP, discípula de Seymour 
Papert no Instituto de Tecnologia de Massachusetts (MIT): "Está provado que o computador não surte efeito na classe de um mau professor". A afirmativa reforça a premissa que só a tecnologia sem a formação do professor para seu uso eficaz não produz resultados.

O avanço crescente do acesso das pessoas as tecnologias digitais de informação, comunicação e expressão (TDICE) aumenta o volume e a velocidade com que as informações são criadas, distribuídas, categorizadas, armazenadas, recriadas e redistribuídas. Isso tem afetado diretamente a educação e as relações sociais, culturais, econômicas em todo o mundo. Bartolomé (2005, p. 1) destaca que "as mudanças que estão se realizando com as tecnologias de informação e de comunicação afetam os processos de aprendizagem de um modo muito mais profundo do que poderia parecer". E o autor complementa: "Não só a informação disponível é cada vez maior - o que implica uma mudança em nossas habilidades e técnicas para processá-la - como também mudam os códigos e o modo de acessá-la".

Como a Educação não é neutra, ela recebe influências sociais, culturais, políticas e tecnológicas da época e do meio onde se situa. Assim, com os avanços tecnológicos atuais, a informática está presente, cada dia mais, nas escolas, como um possível recurso de auxílio no planejamento, execução e melhoria da prática pedagógica em qualquer nível e modalidade da educação, mas enfrenta problemas quanto a sua aceitação e seu uso, por parte de alguns docentes.

\subsection{Tecendo o Problema de pesquisa}

Vivemos uma era de crescente demanda por qualidade, não se pode aceitar que a educação busque apenas atender aos interesses do mercado, nem acreditar que a simples universalização do seu acesso seja entendida como garantia de sucesso, sem se discutir a qualidade do ensino ministrado. Para Pretto:

Neste contexto, a escola pode - e deve - ter uma outra função, um outro papel. Não se trata de garantir, apenas, a universalização do seu acesso. É básico que ela assuma a função de universalizar o conhecimento e a informação. Nessa perspectiva, as novas tecnologias de comunicação passam

a desempenhar um papel vital neste processo. (PRETTO, 1996, p. 221)

Hoje, além da universalização do acesso, a escola vive confrontada com uma nova linguagem que a provoca a propor estratégias inovadoras para mediar a construção do conhecimento e universalizar o acesso à informação, através de processos colaborativos e interativos, os quais as crianças dominam cada vez mais cedo. 
Os professores se veem diante do que pode ser considerado, ao mesmo tempo, um grande desafio e uma grande oportunidade: utilizar as TDICE como meio para construir e difundir conhecimentos e, ainda, para concretizar a necessária mudança de paradigma educacional, centrando seus esforços nos processos de criação, gestão e regulação das situações de aprendizagem. De fato, ao analisar as possibilidades de aplicação dos recursos computacionais no processo educativo, de acordo com as teorias da aprendizagem, Barros e Cavalcante (1999) constatam que é possível usar a tecnologia, tanto numa perspectiva tradicional como numa perspectiva inovadora, haja vista que esses recursos não determinam obrigatoriamente uma abordagem específica de ensino para o professor ou para a escola, que podem fazer uso deles de acordo com seus pressupostos teóricos (DANTAS, 2005).

$\mathrm{Na}$ pesquisa intitulada "Crianças e computadores: um estudo exploratório sobre a informática na Educação Infantil”, Silva (2010) destaca a necessidade de se repensar a finalidade da instalação dos laboratórios de informática nas escolas de educação infantil. Para justificar tal afirmação, a autora aponta as palavras de D'Ávila Gallo (2002, apud Silva, 2010):

Se não se modificar a forma de se implantar a informática - não algo imposto, mas sentido como necessidade, se de fato houver - muitos dos projetos estarão fadados ao fracasso porque por certo, não será a informática que irá corrigir processos envelhecidos e inadequados de ensinoaprendizagem, principalmente quando se está no portal, diante de uma nova forma de se estabelecer relações e comunicações. Algo mais abrangente que as quatro paredes da sala de aula, algo que veio modificar a concepção mesmo de comunicação e que precisa ser visto com seriedade e crítica, se quisermos nos tornar senhores e não servos desta tecnologia (p. 10).

Esse trecho evidencia que a inserção da tecnologia apenas com fins políticos, sem produzir uma contextualização pedagógica, que efetivamente atue nos processos de ensino e aprendizagem, está fadada ao fracasso. Para um uso inovador, ela necessita ser agregada à formação e à preparação do professor para aplicação pedagógica do recurso como forma de inovar e motivar a aprendizagem com crianças pequenas.

Silva (2010) destaca que os professores estão ávidos por novidades e estratégias que, de fato, sejam efetivas no fazer pedagógico, mas eles não esquecem suas limitações quanto ao conhecimento de como melhor podem adequar as tecnologias. Vê-se um conflito entre as dificuldades para apropriação pedagógica dos recursos, decorrentes da formação, e uma constante de estudos que incentivam o uso da tecnologia, apontando-a como capaz de auxiliar o trabalho do professor, com uma nova linguagem, e propiciando experiências virtuais de interação com outros pares para a ressignificação do saber. 
Segundo Barros e Cavalcante (1999, p. 282):

[...] o uso de recursos computacionais em educação será tão prejudicial quanto for o desconhecimento do professor e da escola sobre estas novas tecnologias e a falta de um planejamento de ensino voltado para a construção do conhecimento.

Entretanto, devemos lembrar que a escola precisa assumir o compromisso com a qualidade na educação, repensando a possibilidade de adequar a linguagem digital aos seus processos pedagógicos como forma de preparar as crianças para utilização das tecnologias.

Discussões sobre a educação digital das crianças pequenas considerando o uso de softwares ou dispositivos como tablets, laptops e computadores (SANTOS; BRAGA, 2012) nos mostram que há uma tensão entre o professor e o recurso tecnológico. Essa tensão afeta diretamente a aceitação e o uso desses instrumentos como possibilidades fomentadoras da aprendizagem, fato que se verifica tendo em vista a quantidade de recursos tecnológicos disponibilizados para as escolas públicas de Educação Infantil no Distrito Federal, desde o ano de 2010, e sua pouca utilização com a finalidade pedagógica.

Considerando as inquietações e incertezas advindas das tensões ocasionadas pela descontextualização pedagógica, característica do atual modo como a tecnologia tem sido inserida na escola, e a relação conflituosa entre professor-informática, no âmbito da Educação Infantil, a presente pesquisa surgiu com o intuito de compreender, por meio da explicitação das representações de docentes da escola pública de Educação Infantil, suas concepções e atitudes com relação ao uso da informática na prática educativa.

Partindo do pressuposto de que as representações sociais (MOSCOVICI, 1978) transcendem a esfera individual, por sua superioridade, e atuam na construção do sujeito, pode-se inferir que a compreensão será útil em evidenciar como as intervenções pedagógicas no uso dos recursos tecnológicos estão ligadas às imagens ou ideias que os professores fazem e consolidam dentro do grupo a que pertencem. As representações docentes nos fornecem subsídios para compreender como são percebidas a integração da informática à escola, como encaram as inovações, como as aceitam ou as rejeitam e quais os motivos para adoção de determinados comportamentos de resistência ou de adesão.

Nesse sentido, busca-se, aqui, mapear as questões entrelaçadas às representações que influenciam as relações das docentes com a informática. Para isso, ter-se-á como base a observação do cotidiano da escola de Educação Infantil, onde, durante a permanência da pesquisadora, em função da gestão, muitas inseguranças foram observadas, referentes à 
inserção de tecnologias digitais de informação, comunicação e expressão no cotidiano das crianças pequenas.

Assim, o foco do presente estudo é o professor e suas representações que são alicerçadas em concepções e atitudes advindas do grupo a que pertencem, conforme o que preconiza Brito e Boeno (2012, p. 6):

O professor é figura estratégica na sociedade intensiva de conhecimento [...] necessita pesquisar sempre para repensar sua atuação e reconstruir o conhecimento que tem adquirido ao longo de sua carreira, sendo essa premissa condição necessária para a aprendizagem contínua.

Tendo em vista o escopo do estudo proposto, não há lugar melhor para realizá-lo do que a própria escola de Educação Infantil. Santos e Braga (2012) afirmam que a escola é o local para o compartilhamento dos saberes já construídos e daqueles que estão sendo estabelecidos. Contudo, ela é um vasto campo para exploração do olhar e das vivências em busca das representações dos professores. Em uma perspectiva próxima a essa, Afonso (1993) aponta a escola como uma organização social vasta e complexa. O autor afirma que um estudo sobre inovações em seu contexto requer um aprofundamento na dimensão sociológica que considere os papéis dos agentes envolvidos nas relações educativas. É importante enfatizar que o conceito de inovação na escola, aqui entendido, se dá com base na definição elaborada por Ducros e Finkelsztein (apud AFONSO, 1993). Para esses autores, a inovação na escola se apresenta como uma tentativa de transformar - melhorar - os aspectos precisos do sistema escolar e do funcionamento de um estabelecimento ou da prática pedagógica de certos professores.

O estudo aqui realizado é, portanto, delineado como um estudo das representações sociais, com vistas a investigar e identificar as concepções e atitudes de um grupo de professoras que atuam na Educação Infantil, acerca de suas relações com a informática educativa. Nesse sentido, a seguir, apresentam-se os objetivos que delimitaram a presente pesquisa.

\section{Geral}

Compreender, por meio da explicitação de representações de docentes de escola pública de Educação Infantil, suas concepções e atitudes com relação ao uso da informática nas práticas educativas. 


\section{Objetivos Específicos}

Investigar como as professoras interpretam a inserção da informática na escola de Educação Infantil.

Identificar, por meio de rodas de conversa, as concepções e atitudes das professoras referentes ao uso da informática com crianças pequenas.

Uma tentativa de compreensão das razões subjacentes ao êxito ou fracasso de uma inovação tem que passar pelo conhecimento das concepções e atitudes que os potenciais utilizadores manifestam em relação àquela inovação (AFONSO, 1993). Conforme Ângela Arruda (1998, p. 72) “As representações sociais constituem uma forma de metabolizar a novidade, transformando-a em substância para alimentar nossa leitura de mundo, assim incorporar o que é novo". Então, esta pesquisa intenta compreender, por meio das explicitações de professores de uma escola pública, suas representações em relação ao uso da informática na prática educativa, considerando os anseios e experiências dos professores da Educação Infantil, carentes de uma elucidação teórica-prática sobre o tema em questão.

Ao pesquisar as representações dos professores da educação infantil sobre o uso da informática, somos apresentados a pesquisas que estudam os diferentes usos do computador na Educação (VALENTE, 1993); a artigos que tratam da necessidade de implantação de práticas educativas voltadas à infância e à cibercultura (AMANTE, 2003) e o ensino de crianças considerando as diversas linguagens (AMANTE, 2007); discussões sobre a educação digital das crianças pequenas considerando o uso de softwares ou dispositivos como tablets laptops e computadores (SANTOS; BRAGA, 2012); e estudos sobre a situação da inserção da informática no Distrito Federal (SILVA, 2010). 


\section{A EDUCAÇÃO INFANTIL E AS TECNOLOGIAS DIGITAS DE COMUNICAÇÃO E EXPRESSÃO}

A ampliação do direito à educação de todas as crianças pequenas representa uma conquista importante para a sociedade brasileira. Segundo a Constituição Federal/88, trata-se de um direito subjetivo das crianças com idade entre zero e 5 (cinco) anos (art.208, IV), e é um direito dos trabalhadores urbanos e rurais em relação a seus filhos e dependentes (art. $7^{\circ}$, XXV). Além da Constituição, o direito à educação infantil vem afiançado em outras normativas.

A Lei de Diretrizes e Bases da Educação Nacional - LDB (Lei n 9.394/1996) traz a educação infantil como a primeira etapa da educação básica, que tem como finalidade o desenvolvimento integral da criança.

Art. 29. A educação infantil, primeira etapa da educação básica, tem como finalidade o desenvolvimento integral da criança [...] em seus aspectos físico, psicológico, intelectual e social, complementado a ação da família e da comunidade.

Com a finalidade de regular o acesso e assegurar o direito a todas as crianças, a Lei Federal 12.796/13, em seu artigo $6^{\circ}$, afirma: Art. $6^{\circ}$ é dever dos pais ou responsáveis efetuar a matrícula das crianças na educação básica a partir dos 4 (quatro) anos de idade.

O Estatuto da Criança e do Adolescente - ECA (Lei n 8.069/1990 art. 53, II, V e parágrafo único) além dos direitos previstos na legislação específica da infância: direito de ser respeitado pelos educadores, direito à creche ou pré-escola próxima da residência e direito dos pais ou responsáveis de ter ciência do processo pedagógico, bem como participar das propostas educacionais.

As Diretrizes Curriculares Nacionais da Educação Infantil (2010), em seu artigo $8^{\circ}$, elucidam o objetivo principal da etapa de educação infantil, que é impulsionar o desenvolvimento integral das crianças ao garantir a cada uma delas o acesso à construção de conhecimentos e à aprendizagem de diferentes linguagens, assim como o direito à proteção, à saúde, à liberdade, ao respeito, à dignidade, à brincadeira, à convivência e à interação com seus pares etários, com crianças de diferentes faixas etárias e com os adultos.

O conceito de infância é aparentemente novo dentro da configuração social e cultural do mundo. Em seus estudos, Guimarães (2008) apresenta-nos uma síntese sobre o tema: somente a partir do Século XVIII a infância começa a ser objeto de novos olhares e 
preocupações. Na antiguidade, crianças e adultos eram tidos como seres biológicos; as pobres cresciam para atender ao mundo do trabalho e as ricas eram vistas como miniaturas dos adultos.

Nos séculos XIX e XX, com o aprofundamento das pesquisas e das ciências, surgem e avançam estudos na psicologia, na medicina e na pedagogia. Tais estudos promovem discursos que trazem, em seu contexto, um ideário de criança, aparecem reflexões sobre os direitos das crianças, prerrogativas de cidadania, teorias do desenvolvimento, periodicidade da vida infantil. São divulgadas normas de higiene e cuidados com as crianças, investe-se em campanhas de amamentação, criam-se instituições de atendimento, como as creches e jardins da infância. Elabora-se um modelo de infância, um modo de ser criança na cultura ocidental que norteia as práticas pedagógicas construídas para esta fase da vida.

No Brasil, com o advento da Constituição Federal (CF/88), as temáticas da educação para a infância ganharam sentido no cenário social. Vê-se a virada do processo de valorização da infância porque, desde então, o enfoque saiu da tutela da família e recaiu sobre o direito. Passa-se a considerar a criança como sujeito de direitos: direito à vida, saúde, alimentação, educação, lazer, cultura, dignidade, respeito, liberdade, convivência familiar e comunitária. Uma das consequências dessa valorização da infância é o reconhecimento da Educação Infantil como dever do Estado e direito da criança.

Um dos atrativos da escola, para as crianças pequenas, é o contato com os diversos elementos do mundo e a interação com os objetos ou pessoas, com o objetivo de promover as aprendizagens e o desenvolvimento integral dos pequeninos. Pata Gomes (2011), hoje é possível perceber que as crianças que estão chegando às escolas de educação infantil, em sua maioria, já tiveram oportunidade de fazer uso de algum tipo de tecnologia. O contato da criança com a linguagem digital está acontecendo cada vez mais cedo. Segundo Mello e Vicária (2008, p. 486):

Crianças com menos de 2 anos já se sentem atraídas por vídeos e fotos digitais. A intimidade com o computador, porém, costuma chegar aos 4 anos. Nessa idade, já deslizam o mouse olhando apenas para o cursor na tela. Aos 5 , reconhecem ícones, sabem como abrir um software e começam a se interessar pelos primeiros jogos virtuais, como os de associação ou de memória.

As Diretrizes Curriculares Nacionais para a Educação Infantil (DCNEI) (BRASIL, 2010, p. 25-27) apresentam os seguintes eixos para as práticas pedagógicas na Educação Infantil: 
As práticas pedagógicas que compõem a proposta curricular da Educação Infantil devem ter como eixos norteadores as interações e a brincadeira e garantir experiências que:

$\checkmark$ Promovam o conhecimento de si e do mundo por meio da ampliação de experiências sensoriais, expressivas, corporais que possibilitem movimentação ampla, expressão da individualidade e respeito pelos ritmos e desejos da criança;

$\checkmark$ Favoreçam a imersão das crianças nas diferentes linguagens e o progressivo domínio por elas de vários gêneros e formas de expressão: gestual, verbal, plástica, dramática e musical;

$\checkmark$ Possibilitem às crianças experiências de narrativas, de apreciação e interação com a linguagem oral e escrita, e convívio com diferentes suportes e gêneros textuais orais e escritos;

$\checkmark$ Recriem, em contextos significativos para as crianças, relações quantitativas, medidas, formas e orientações espaço temporais;

$\checkmark$ Ampliem a confiança e a participação das crianças nas atividades individuais e coletivas;

$\checkmark$ Possibilitem situações de aprendizagem mediadas para a elaboração da autonomia das crianças nas ações de cuidado pessoal, autoorganização, saúde e bem-estar;

$\checkmark$ Possibilitem vivências éticas e estéticas com outras crianças e grupos culturais, que alarguem seus padrões de referência e de identidades no diálogo e conhecimento da diversidade;

$\checkmark$ Incentivem a curiosidade, a exploração, o encantamento, o questionamento, a indagação e o conhecimento das crianças em relação ao mundo físico e social, ao tempo e à natureza;

$\checkmark$ Promovam o relacionamento e a interação das crianças com diversificadas manifestações de música, artes plásticas e gráficas, cinema, fotografia, dança, teatro, poesia e literatura;

$\checkmark$ Promovam a interação, o cuidado, a preservação e o conhecimento da biodiversidade e da sustentabilidade da vida na Terra, assim como o não desperdício dos recursos naturais;

$\checkmark$ Propiciem a interação e o conhecimento pelas crianças das manifestações e tradições culturais brasileiras;

$\checkmark$ Possibilitem a utilização de gravadores, projetores, computadores, máquinas fotográficas, e outros recursos tecnológicos e midiáticos. (BRASIL , 2010, p. 25-27)

É inquestionável a importância da educação infantil, quer porque através dela se desenvolvem as mais variadas competências e habilidades, quer porque contribui para a definição de normas, valores e atitudes, cuja interiorização e apropriação se projetará, não só nos níveis de ensino subsequentes, como na vida do futuro cidadão. Mas para que a criança possa tirar o máximo proveito dessa primeira etapa da educação, ela deve ter um investimento que assegure uma prática educativa de qualidade. Esta prática de qualidade pode também ser estimulada pela utilização de tecnologias digitais de comunicação e expressão, entendidas não como um mero recurso didático, mas como um instrumento cultural utilizado na prática pedagógica, com finalidades sociais autênticas que lhe confiram significado. 
O trabalho com informática, em uma sala de educação infantil, pode constituir-se em uma possibilidade para que as crianças utilizem a informática inserida um meio cultural de que se apropriam, no sentido de realizar atividades que assumem significado real e que se inserem num contexto integrado e social de aprendizagem. Uma utilização adequada da tecnologia é aquela que permite expandir, enriquecer, diferenciar, individualizar e implementar a globalidade dos objetivos curriculares.

Integrar a linguagem digital a educação infantil tem a possibilidade de dar lugar a ricas e novas formas e experiências de aprendizagem. Segundo Moreira (2002, p.12), quando aplicadas de modo apropriado, as tecnologias podem desenvolver as capacidades cognitivas e sociais, devendo ser utilizadas como uma de muitas outras opções de apoio à aprendizagem. A integração dessas diversas experiências às práticas pedagógicas da Educação Infantil proporcionam um vasto ambiente de aprendizagem e experimentação que tem convidado os professores a repensar seu trabalho junto às crianças pequenas em creches e pré-escolas, respeitando os seguintes princípios:

\footnotetext{
Éticos: da autonomia, da responsabilidade, da solidariedade e do respeito ao bem comum, ao meio ambiente e às diferentes culturas, identidades e singularidades.

$\checkmark \quad$ Políticos: dos direitos de cidadania, do exercício da criticidade e do respeito à ordem democrática.

$\checkmark$ Estéticos: da sensibilidade, da criatividade, da ludicidade e da liberdade de expressão nas diferentes manifestações artísticas e culturais. (BRASIL, 2010, p. 15)
}

Com a inserção da informática, abre-se um leque de oportunidades para que, desde cedo, a criança pequena acesse novas manifestações da linguagem decorrentes das tecnologias digitais, que podem promover a estimulação de suas mentes e a potencialização de seu desenvolvimento intelectual, paralelamente ao seu desenvolvimento psicossocial, uma vez que sua coordenação motora está se estabelecendo concomitantemente a seus gostos e relações sociais (AMANTE, 2007b). Entre os benefícios da integração de recursos tecnológicos à prática pedagógica da Educação Infantil, respeitando-se os eixos do currículo proposto para o referido nível de ensino, AMANTE (2007b, p. 52) destaca:

$\checkmark$ O desenvolvimento da linguagem e da leitura de mundo incentivado
pelos jogos, livros digitais e estórias que permeiam o mundo da fantasia
infantil. Estes estimulam a linguagem, exploram a o discurso e a fluência
verbal, a interação com outros pares.
$\checkmark \quad$ O estímulo à aprendizagem concreta de conceitos matemáticos, tais
como: reconhecimento de formas, contagem e classificação. O
favorecimento da aprendizagem do pensamento matemático. As crianças têm 
a possibilidade de associar experiências virtuais diretas com a utilização de programas de computador, apresentando maior competência em operações de classificação e pensamento lógico do que aquelas que apenas tiveram acesso à experiência manipulativa concreta.

$\checkmark$ Aprendizagem do conhecimento de mundo, conforme as possibilidades disponibilizadas pela internet, que podem proporcionar aos educadores e às crianças oportunidades únicas de acesso às pessoas, às imagens, aos sons e às informações diversificadas e dificilmente acessíveis de outro modo, constituindo-se como poderosos recursos educacionais.

$\checkmark \quad$ Compreensão e entendimento da diversidade em contextos sociais e culturais diversos.

Considerando os benefícios potenciais, as políticas governamentais para a primeira infância têm fomentado o uso de recursos informatizados, como, por exemplo, a implantação de laboratórios de informática nos Centros de Educação Infantil e Jardins de Infância espalhados pelo Distrito Federal. Referente ao uso da informática na escola, Santos (2009, p.17) afirma :

[...] é apontado como fator que pode efetivamente contribuir para um avanço qualitativo dos processos de ensino e de aprendizagem, de modo que tanto as agências governamentais quanto a iniciativa privada têm investido na adoção de programas de informatização do ensino e na produção de meios digitais e telemáticos para uso em educação.

Com base na perspectiva de que as TDCIE's podem contribuir para o avanço qualitativo, o Currículo em Movimento da Educação Básica para a Educação Infantil, implementado no ano de 2013, na Secretaria de Estado de Educação do DF, traz um capítulo dedicado a explanar o trabalho a ser desenvolvido com as crianças a respeito da linguagem digital, como forma de promover o desenvolvimento integral, oportunizando pela manipulação de tecnologias digitais formas diversas de brincar, manipular e explorar imagens e sons. Sendo assim:

Sua presença constante e a facilidade de acesso, tanto em casa quanto na escola, postulam a inclusão da tecnologia como elemento estruturante de nossa ação: A presença crescente de novas tecnologias de pesquisa e de arquivamento de informações, de novos recursos de comunicação no cotidiano das comunidades, a maior acessibilidade de uso de gravadores, projetores e computador por muitas famílias, e a presença mais frequente desses instrumentos, na instituição de Educação Infantil, abre para as crianças novas oportunidades de aprendizagem. Cada vez mais se vê crianças pequenas utilizando de modo competente, embora básico, elementos da tecnologia digital, o que acarretaria as possibilidades de desenvolvimento para as novas gerações. (FORTALEZA, 2011, p.81)

É essencial que as novas tecnologias sejam inseridas e incorporadas à rotina da Educação Infantil. Segundo as orientações expressas no tex to do Currículo em Movimento: 
A utilização adequada das novas tecnologias propicia o descobrimento de potencialidades e capacidades. Todavia, é necessário que haja um projeto pedagógico que dê significado a esse trabalho: quando, como e o porquê do uso de um determinado recurso. Outro cuidado é ter em conta que todo esse trabalho deve acontecer "em situações lúdicas que respeitem a forma da criança dar sentido aos materiais que utiliza e às representações que produz". (FORTALEZA, 2011, p.82)

As escolas de Educação Infantil estão repletas de pequeninos que dominam os recursos informatizados. É a "Geração Polegar" (MOURA, 2009), a "thumb generation" (RHEINGOLD, 2003), as “thumb tribes" (RHEINGOLD, 2003), ou ainda, os nativos digitais (PRENSKY, 2001). Tais denominações nomeiam os indivíduos que já nasceram imersos no mundo digital e que, cada dia mais cedo, aprendem e dominam os recursos digitais de forma veloz. Enquanto os professores, por não terem nascido ou se formado no contexto de tal efervescência tecnológica, necessitam de capacitação em serviço e enfrentam dificuldades, tais como: a falta de tempo, as turmas lotadas, a deficiência no desenvolvimento pedagógico desde a Universidade, a ausência de equipamentos adequados na escola e a formação continuada inadequada.

Neste sentido, a escola anseia por um repensar de cenários educativos que possibilitem a interação, a colaboração e a aprendizagem, mediadas pelas tecnologias digitais de comunicação e expressão. Em se tratando de crianças pequenas, a mudança propõe uma reflexão acerca da compreensão, por meio do estudo das representações dos professores, quanto ao uso e integração da informática na Educação Infantil. Dessa reflexão emergem questões que não se esgotam e que são ligadas à interpretação das dificuldades que os docentes da Educação Infantil enfrentam para a conexão da informática à sua prática pedagógica, bem como o entendimento de porque os recursos informatizados são subutilizados nas escolas ou como eles podem ser mais bem aproveitados.

A utilização da linguagem digital desafia a todos, mais especialmente os profissionais docentes, porque muda alguns paradigmas aos quais nos acostumamos. Em uma "sociedade marcada pelo digital”, precisamos: “[...] aprender a solucionar problemas e não somente a dar respostas certas ou erradas; [...] dominar códigos de linguagens, além de conhecer e saber utilizar as ferramentas disponíveis e seus recursos; [...] ter consciência para refletirmos e agirmos de forma a atender a essa nova demanda [...]" (BELO HORIZONTE, 2009, p.124).

A escola de Educação Infantil procura investir em políticas para facilitar a integração das tecnologias digitais de informação, comunicação e expressão (TDICE), no intuito de tentar auxiliar a docente a compreender e assimilar as mudanças decorrentes da emergência da 
Sociedade da Informação. Programas de inserção de recursos tecnológicos, tais como: o Projeto Um Computador por Aluno (UCA), a lousa digital, os tablets para professores do Ensino Médio e os computadores - Micro Kids - específicos para a Educação Infantil -, procuram dar conta da demanda da escola por tecnologia. No entanto, o uso pedagógico, de fato, é mínimo.

Diversas pesquisas apontam que professores simplesmente não sabem o que fazer. É o que nos informam Altoé (1993, 1996, 1998, 2001, 2002, 2005, 2008), Almeida (1999, 2000), Moraes (1997,1999) e Valente (1991, 1993b, 1996, 1999, 2003), para quem os professores se encontram, de modo geral, despreparados para fazer uso de tais recursos tecnológicos na prática pedagógica, e resistentes para utilizá-los, seja por não dominarem as tecnologias, seja por se sentirem incapazes diante da agilidade das crianças pequenas. $\mathrm{O}$ aparato tecnológico que cerca as crianças, no mundo atual, tende a intrigar os professores em geral, pois eles percebem uma mudança na cultura da infância, no modo como constroem os conceitos, sistematizam o mundo e interagem com os pares. Neste sentido, segundo Prensky, (2001, p. 47):

Os alunos de hoje - do maternal à faculdade - representam as primeiras gerações que cresceram com esta nova tecnologia. Eles passaram a vida inteira cercados e usando computadores, vídeo games, tocadores de música digitais, câmeras de vídeo, telefones celulares, e todos os outros brinquedos e ferramentas da era digital. Em média, um aluno graduado atual passou menos de 5.000 horas de sua vida lendo, mas acima de 10.000 horas jogando vídeo games (sem contar as 20.000 horas assistindo à televisão). Os jogos de computadores, e-mail, a Internet, os telefones celulares e as mensagens instantâneas são partes integrais de suas vidas.

Todavia, tal cenário não tem se refletido no cotidiano das escolas de Educação Infantil. Estudos apontam para a necessidade de atualização do cotidiano escolar no referido nível de ensino - desde a aquisição de equipamentos mais modernos, mudanças na infraestrutura, adequação no currículo, até a revisão da política de formação de profissionais docentes que ensinem novas competências (MORAN, 2000, 2005; NOVOA, 1991; LEVY, 1993; MERCADO, 1999). Ou seja, a escola de Educação Infantil confronta-se com a necessidade de aprender a conviver com a linguagem digital, sob pena de tornar-se desconectada das dinâmicas sociais fora do ambiente escolar. Em outros termos, frente às novas condições que estão sendo produzidas socialmente, no âmbito da Sociedade da Informação, os professores devem repensar seus métodos e técnicas de ensino para acompanhar a velocidade da mudança. No entanto, nem sempre as inovações apresentadas são 
bem vistas ou bem aceitas pelos docentes. Paiva (2008) aborda, a seguir, a problemática da apropriação de tecnologias na escola por meio de uma classificação em estágios: rejeição, adesão e normalização:

Quando surge uma nova tecnologia, a primeira atitude é de desconfiança e de rejeição. Aos poucos, a tecnologia começa a fazer parte das atividades sociais da linguagem e a escola acaba por incorporá-la em suas práticas pedagógicas. Após a inserção, vem o estágio da normalização, definido por Chambers e Bax (2006, p. 465) como um estado em que a tecnologia se integra de tal forma às práticas pedagógicas que deixa de ser vista como cura milagrosa ou como algo a ser temido. (PAIVA, 2008. p.1)

Tais estágios indicam que inovar na escola é uma tarefa árdua, que requer entendimento sobre a concepção, o modelo de funcionamento e as estratégias propagadas para a implantação de mudanças. Moran $(2005$, p. 2) enfatiza a referida complexidade ao afirmar que:

É um desafio aprender a gerenciar o processo de aprendizagem com alunos conectados pela Internet, tanto na educação presencial como na educação a distância. Organizações educacionais precisam rever seus processos de organização, flexibilizar seus currículos, adaptar-se a novas situações, formar seus docentes no gerenciamento da aprendizagem com tecnologias telemáticas.

A escola, em geral, tem dificuldades em incorporar mudanças advindas da Sociedade de Informação, e recursos informatizados têm sido utilizados para manter a atual estrutura ali engessada, visando perpetuar ações e práticas consolidadas, sem mudar a sala de aula e o modo de ensinar (PAPERT, 2008).

Os professores são os "agentes" que tem o papel de executores das inovações que integram o sistema educativo. O sucesso ou fracasso das inovações tecnológicas, propostas para a escola de Educação Infantil, passam, necessariamente, pelas docentes e pela forma como estas reagem em relação à inserção de recursos informatizados em seu dia a dia. Para Morrish (1981) "a transformação e melhoria da educação dependem principalmente daquilo que os professores desejam e do que fazem", bem como, ainda, de como interpretam o processo educativo como um todo. Nesse sentido, faz-se importante verificar como as professoras compreendem as TDCIE dentro das relações pedagógicas da Educação Infantil, partindo das representações sociais instituídas e alimentadas pela prática. Esses pontos precisam ser elucidados para o entendimento do que há por trás da aceitação e uso de recursos informatizados presentes nas escolas da etapa de ensino aqui analisada. 


\subsection{O uso da Informática na educação Infantil - Modalidades e Pressupostos}

Com o intuito de compreender as representações das docentes da educação infantil acerca do uso da informática, o levantamento do entendimento das modalidades e pressupostos que afirmam a inserção de recursos tecnológicos nas escolas é muito interessante. Isso não apenas para conhecimento, mas para verificação de como estes posicionamentos agem como influenciadores das docentes e atuam nas concepções e atitudes quanto à inserção e à utilização prática que é realizada dos recursos, sendo considerados como atuantes na construção de representações sociais.

Afonso (1993) afirma que o sistema educativo não se confina apenas aos limites físicos, mas que está aberto a influências advindas de todos os meios, entretanto, para se considerar a extensão da adoção ou rejeição de determinado objeto dentro da escola, faz-se necessária a análise da inovação com base na mudança de atitudes e comportamentos que está impele aos envolvidos no processo.

\subsubsection{Modalidades de uso da Informática na educação Infantil}

O entendimento das modalidades de uso da informática na Educação Infantil é justificado tendo em vista que a instituição educativa precisa considerar a realidade atual de interação, cada vez mais cedo, das crianças com o mundo digital. Elas estão cercadas de linguagens, sons e imagens que necessitam ser significadas dentro de práticas pedagógicas que proporcionem aprendizagens diversas.

Analisando as modalidades de uso do computador, Afonso (1993) enumera quatro concepções principais que colaboram na construção de percepções de uso e aceitação de recursos informatizados no ambiente educativo, a saber:

Concepção como máquina de ensinar - A tecnologia é vista como substituta do professor. Tal concepção está ligada às estruturas informatizadas que controlam a aprendizagem e que prendem o aluno em um caminho próprio, estático, que não permite a criatividade e não incentiva a motivação como forma de aprendizagem.

Concepção como objeto de estudo - A própria tecnologia é estudada em suas variáveis, sua história, seu impacto social e seus efeitos. O computador é tido como o próprio conteúdo de estudo.

Concepção como recurso facilitador de tarefas - Os professores visualizam os recursos tecnológicos, em especial, o computador, como uma ferramenta facilitadora de 
tarefas dos professores e alunos (para processar textos, facilitar cálculos matemáticos, elaborar e selecionar dados, desenhar utilizar simulações). Esta é a concepção mais adotada, que visa aproximar a informática da escola. Defensores dessa concepção acreditam que todo e qualquer recurso informatizado tem possibilidades ou tarefas que servem para auxiliar na aprendizagem, seja completando ou motivando-a.

Concepção como "máquina ensinável" - Privilegia a utilização deste como uma ferramenta programável, capaz de desenvolver capacidades cognitivas do aluno, através do controle que exerce sobre a máquina, ensinando-o.

Um estudo realizado por Silva (2010) procurou identificar como os professores da Educação Infantil, no Distrito Federal, têm utilizado a informática em suas práticas pedagógicas. Segundo a autora, os poucos professores que se servem de tal tecnologia, a utilizam como recurso facilitador de tarefas, fonte de pesquisa de materiais para enriquecer as aulas em blogs e sites educativos, como forma de enriquecer o planejamento. A pesquisa revela, no entanto, que a maior fronteira para o uso da informática, na referida modalidade de ensino, reside na falta de domínio de métodos e técnicas, por parte do professor.

Santos e Braga (2012) também pesquisaram a utilização de recursos informatizados na Educação Infantil, apontando que determinados recursos, em especial, o computador, são "passatempos eletrônicos" no que se refere ao trabalho com conteúdos, sem favorecimento da interatividade e da interação com fins curriculares.

Entende-se que o uso da informática na educação tem diversos significados, dependendo da visão educacional e da condição pedagógica em que o computador é utilizado. Sob essa ótica, é importante mencionar que a informática na educação pode significar, em um de seus paradigmas, a inserção do computador no processo de aprendizagem dos conteúdos curriculares de todos os níveis e modalidades de educação, se aliado a práticas pedagógicas.

\subsubsection{Pressupostos de uso da informática na Educação Infantil}

No intuito de ajudar as crianças a lidar com os recursos informatizados, a presença constante e a facilidade de acesso, tanto em casa quanto na escola, postulam a inclusão da informática como uma possibilidade de desenvolvimento de novas competências necessárias na sociedade atual. Afonso (1993) identifica quatro pressupostos que norteiam a inserção de recursos tecnológicos no contexto escolar, a saber:

Pressupostos de ordem social - A informática vai, mais cedo ou mais tarde, dominar toda a sociedade; logo, todos devem conhecer o funcionamento e as aplicações desta; todos 
precisam aceitar que a Sociedade da Informação já é parte do contexto educativo, e a escola precisa conhecer como esta funciona e adequar-se à nova realidade para integrar com sucesso os processos de produção de conhecimento. Santos (2008) destaca que a escola precisa acompanhar as mudanças da sociedade e assumir novas funções para atingir seu objetivo primordial: a aprendizagem. Percebe-se, atualmente, uma democratização do saber e do acesso às tecnologias, o que tem facilitado o entendimento dos processos de produção do conhecimento. Tal perspectiva tem favorecido o crescimento de práticas que trabalham o uso de recursos como forma de mudança social. Uma das constatações apresentadas por Afonso (1993) quanto aos pressupostos de inserção de tecnologias na escola, que figuram nas representações de ordem social, é que estas advêm de uma concepção de modernidade, como sendo uma oportunidade para que a escola não fique isolada do contexto tecnológico e possa promover a inclusão digital dos alunos que, devido às condições econômicas, muitas vezes, não possuem acesso à tecnologia.

Pressupostos de ordem vocacional - A informática na escola pode contribuir para preparar os alunos para postos de trabalho bem remunerados. Tal perspectiva demonstra a visão funcionalista da escola que intenta que todo conhecimento tem de ter uma aplicação útil, voltada às tarefas de âmbito econômico na sociedade. Almeida (2000) refere-se ao computador como "uma máquina que possibilita testar ideias ou hipóteses, que levam à criação de um mundo abstrato e simbólico, ao mesmo tempo em que permite introduzir diferentes formas de atuação e interação entre as pessoas", sendo, por conseguinte, um equipamento que assume, cada vez mais, diversas funções. Como ferramenta de trabalho, contribui de forma significativa para a elevação da produtividade, para a diminuição de custos e para a otimização da qualidade dos produtos e serviços. Logo, quanto mais cedo o contato com a informática, mais a probabilidade do indivíduo em dominar as suas aplicações cotidianas.

Pressupostos de ordem pedagógica - Estes encaram a informática como fomentadora de uma nova possibilidade de aprendizado, pensamento e crescimento emocional e cognitivo. Neste pressuposto, talvez se tenha a maior fonte de resistência dos professores que ainda não enxergaram esta nova possibilidade dentro da Educação Infantil. Resistem, pois o uso que fazem da tecnologia tem deixado a desejar quando o tema é a geração de facilidades em ensinar e aprender. Borges (1999) enfatiza o uso de recursos tecnológicos como suporte ao professor, frisando que tais instrumentos podem ser colocados à disposição, na tentativa de possibilitar novas formas de interação e produção de conhecimento. Ao tratar a questão do uso do computador como recurso didático, o autor acrescenta que é possível simular, praticar 
ou vivenciar situações, podendo até sugerir conjecturas abstratas, fundamentais à compreensão de um conhecimento ou modelo de conhecimento que se está construindo.

Pressuposto catalítico - As escolas podem ser mudadas ou modificadas; podem incorporar novos meios de aprendizagem que facilitem a vida do professor e do aluno. Bartolomé (2005, p. 1) destaca que "as mudanças que estão se realizando com as tecnologias de informação e de comunicação afetam os processos de aprendizagem de um modo muito mais profundo do que poderia parecer", complementando: "Não só a informação disponível é cada vez maior - o que implica uma mudança em nossas habilidades e técnicas para processála - como também mudam os códigos e o modo de acessá-la”. É necessário romper paradigmas frente à efervescência digital que irradia os cenários sociais, incluindo-se o cenário escolar. É possível observar que tais pressupostos, direta ou indiretamente, sempre estiveram presentes nas políticas de implantação de recursos informatizados.

A consideração dos referidos pressupostos, permite ponderar que a implantação de laboratórios de informática na Educação Infantil atende a uma visão de que a inserção de tecnologia pode melhorar a Educação e, quanto mais cedo ela compuser o cotidiano escolar, mais cedo se perceberá uma melhoria no ambiente de aprendizagem. Neste sentido, segundo Haetinger (2005):

O acesso à mídia impressa e eletrônica, ao vídeo, ao computador, às redes e apropriação de suas linguagens e estéticas, não é uma utopia ou um desvario, é a condição básica da habitação do cidadão ao diálogo social, afetivo, político, profissional, o cidadão da sociedade informático-mediática necessita adquirir habilitação técnica e linguística que lhe permita transitar e sobreviver no meio informacional na qual está imerso. (HAETINGER, 2005, p.134)

A inserção das novas tecnologias digitais nos processos educativos envolve uma mudança mais profunda do que apenas equipar a escola. Requer o envolvimento dos professores que, muitas vezes, são deixados de lado com suas dificuldades cotidianas. $\mathrm{Na}$ Educação, a tecnologia e a inovação ampliam os conceitos de aula, espaço, tempo e comunicação. Quando absorvidas e bem exploradas pela escola, possibilitam maior o domínio dos conhecimentos e a integração do ensino à vida (SILVA; PINHO, 2012). Mas quando são inseridas com base em pressupostos que não consideram os professores, essas provocam uma atitude defensiva e de refúgio no conhecido ou no consolidado.

Considerando a sala de aula da Educação Infantil, o desafio está em integrar o uso da tecnologia de forma inovadora ao ensino, de modo que ela colabore no desenvolvimento das múltiplas linguagens infantis, nas diferentes formas de representação e na expressão musical, 
associadas às expressões verbal e visual, de forma criativa, combinando sistemas simbólicos e tecnologia (SILVA; PINHO, 2012).

\subsubsection{Relatos experiências de uso de recursos tecnológicos na Educação Infantil}

A busca por relatos de experiências traz à tona algumas das dificuldades da Educação Infantil, enquanto prática instituída dentro da sociedade contemporânea. Tem-se a ausência de divulgações de trabalhos e projetos dentro especificamente desta faixa etária, percebe-se uma quantidade de trabalhos incipientes que objetivam uma melhor compreensão de como os educadores e as crianças se apropriam dos equipamentos tecnológicos.

O uso de ferramentas tecnológicas educacionais, desde cedo, possibilita a ampliação de experiências lúdicas importantes para a formação de indivíduos mais criativos, que estarão adquirindo novos conhecimentos e integrando-se com um novo modo de aprender e de interagir com a sociedade. Para Lévy (2010):

[...] um mundo virtual, no sentido amplo, é um universo de possíveis, calculáveis a partir de um modelo digital. Ao interagir com o mundo virtual, os usuários o exploram e o atualizam simultaneamente. Quando as interações podem enriquecer o modelo, o mundo virtual torna-se um vetor de inteligência e criação coletivas. ( p. 75)

Ao se pesquisar as experiências virtuais de inserção de tecnologias digitais na educação infantil, para a faixa de crianças entre zero a cinco anos, somos confrontadas com a história desta etapa educacional que, por anos, não foi considerada como essencial para o desenvolvimento infantil e ficou destinada, em grande parte, às instituições educacionais privadas. O uso de tecnologias é algo bem recente a se contar pela propagação dos estudos em outras etapas educacionais. Isto é justificado pela dificuldade de adaptação das ferramentas existentes aos currículos escolares e aos temas explorados nessa faixa etária, com vistas a levar para a criança a possibilidade de expressar seus pensamentos e imaginações de uma forma lúdica e divertida, tornando o processo de aprendizagem mais interessante.

Entre as experiências encontradas, tem-se a do XVI Simpósio Brasileiro de Informática na Educação, do ano de 2005, que traz o relato do espaço digital nomeado como "Legal: Ambiente de Autoria para Educação Infantil apoiada em Meios Eletrônicos Interativos". Criado baseando-se em uma pedagogia de projetos, o ambiente permite que a criança possa expressar toda sua criatividade e imaginação para criar e contar histórias. Através de uma biblioteca de imagens e sons, disponibilizados pelo ambiente, a criança 
poderá criar um cenário, inserir objetos e associar sons a eles, além de utilizar o recurso de gravação para gravar sua própria voz, narrando sua história. Tem-se que, além do estímulo à criatividade, o ambiente oferece recursos para o uso da linguagem oral, possibilitando a ampliação do vocabulário da criança.

Com a ideia de inserir a tecnologia como algo natural e lúdico, sem deslumbramento, dentro da perspectiva de que a criança tem o direito de interagir com os mais diversos tipos de materiais e linguagens, tem-se a experiência de Poços de Caldas MG, do ano de 2006, com crianças e professores, na qual, os docentes foram capacitados para o uso didático do laboratório de informática no trabalho com as crianças. O diferencial da experiência foi a capacitação oferecida na escola. No ano de 2008, os docentes desenvolveram um projeto interdisciplinar com o intuito de trabalhar a articulação das mídias com os diversos conteúdos e experiências próprias da Educação infantil, utilizando o software Kid Pix que trabalha a escrita e leitura (LISBOA, 2008).

Em Gomes (2011), tem-se o relato da experiência da Lousa Digital, que foi implantada em escolas privadas na região de Campinas, Indaiatuba. A equipe docente participou de uma capacitação para o uso do recurso tecnológico na Faculdade de Educação da Unicamp, no ano de 2010. Estes tiveram a oportunidade de acessar a interface interativa e explorar possibilidades com o uso de imagens, sons, links interativos, fotografias e outros componentes do aparato tecnológico. As crianças foram inseridas a partir da metodologia de projetos interdisciplinares.

A respeito das situações lúdicas que favorecem a aprendizagem com o auxílio de recursos tecnológicos, Mattei (2011) traz um artigo intitulado "o prazer de aprender com a informática na Educação Infantil" que relata uma experiência bem sucedida de uso de um software educativo de desenho com crianças pequenas, em Blumenau Santa Catarina. Entre as potencialidades observadas, a autora relata que a criança "passa a desenvolver competências e habilidades, como ter autonomia, pensar, criar, aprender e pesquisar". Na vivência de pesquisa relatada no artigo, Mattei (2011) pontua que o uso de recursos tecnológicos, no caso específico do computador:

\footnotetext{
$\checkmark \quad[\ldots]$ promove a integração professor-aluno transformando-os em parceiros no processo ensino-aprendizagem;

$\checkmark \quad$ O aprendizado [...] de uma maneira criativa, prazerosa e desafiadora.

$\checkmark \quad$ Desenvolveu o pensamento crítico dos alunos.

$\checkmark \quad$ Estimulou a pesquisa e a criatividade nos alunos.
} 
$\checkmark \quad$ Os alunos sentiram uma imensa alegria, motivação, emoção, cooperação, interação principalmente por terem sido atores e autores de seu próprio trabalho. (p. 14)

O professor é a figura central para que a inserção da tecnologia se configure como inovação na prática pedagógica. Ele precisa sentir-se desafiado a incorporar a linguagem digital a seus projetos pedagógicos. 


\section{O ESTUDO DAS REPRESENTAÇÕES DE PROFESSORES SOBRE A INFORMÁTICA NA EDUCAÇÃO INFANTIL}

Um estudo das representações sociais da informática no contexto educacional tem como objetivo compreender supostos "medos", "resistências" ou "fascínios", elementos “presentes no imaginário individual e coletivo dos docentes" (CARNEIRO, 2002). O presente estudo aponta certa complexidade por utilizar-se da realidade ancorada na representação social, em que são considerados conteúdos representativos, tais como: a linguagem, os discursos, as práticas, os dispositivos materiais, a participação social e cultural dos indivíduos, de um grupo ou de uma coletividade, sem realizar prejulgamentos, bem como o gesto de lembrança de que a representação social é uma matéria concreta.

A teoria das representações sociais apresenta-se como um novo olhar para antigos problemas e novos desafios no campo da educação. Ela tem seu escopo delineado nos comportamentos e atitudes mediados pela linguagem, que são construídos no jogo social, na espontaneidade dos encontros, no entrelaçamento de subjetividades e está ancorada em situações vividas pelos sujeitos na cotidianidade, instaurando-se como um modo de entender os problemas sociais no âmbito da educação.

Tendo em vista a complexidade da educação, alguns referenciais científicos clássicos não conseguem clarificar teoricamente a imensidão das relações que emergem das interações educativas, diante disso tem-se a teoria das representações sociais que oferece essa possibilidade ao deixar de lado a concepção reducionista e fragmenta de sujeito comum. Ela trabalha com a pesquisa entrelinhas, ou seja, compreende que é impossível distinguir os discursos originários das formações teóricas daqueles que provém das práticas executadas.

No âmbito da educação e das práticas pedagógicas, é impossível ao educador, no desenvolvimento do seu trabalho, separar o eu pessoal de seu eu profissional. Cerqueira (2012) afirma:

Esses profissionais, sujeitos históricos e socialmente revistos ao longo de suas trajetórias de vida, não se constituem mais naqueles idealizados profissionais que deveriam separar seus interesses, desejos, vontades, angústias, sonhos, enfim, separar sua vida pessoal da profissional. (p.81)

A representação coletiva não é uma espécie de falsa consciência que mascara a realidade, mas antes articula a ideia e a ação social de modo a delinear a vida cotidiana das pessoas, criando uma espécie de consciência coletiva que atribui função social aos sujeitos no 
espaço social e no tempo. Desse modo, a dita sociedade real e ideal se articula não pelo seu caráter antagônico, mas pela coesão que criam. "Porque uma sociedade não é constituída simplesmente pela massa dos indivíduos que a compõem, pelo solo que a ocupa [...], mas, antes de tudo, pela ideia que ela faz de si mesma" (DURKHEIM, 1989, p.500 apud DE CARVALHO, 2011)

A teoria das Representações sociais foi elaborada a partir das reflexões de Moscovici sobre a consciência coletiva, explicada por Émile Durkein como um conjunto de crenças e de sentimentos comuns à média da população de uma determinada sociedade, formando um sistema com vida própria, que exerce uma força coercitiva sobre seus membros; como, por exemplo, o devoto que, ao nascer, já encontra as crenças e práticas religiosas estruturadas e em plena atividade. Se estas práticas já existem, é porque estão fora dele, mas, mesmo assim, exercem influência sobre seu comportamento e crenças. É um sistema que existe fora do indivíduo, mas que o controla pela pressão moral e psicológica, ditando as maneiras como a sociedade espera que se comporte.

Assim, entende-se que a origem das representações se insere nas relações estabelecidas entre os indivíduos e os grupos. Pode-se dizer que as representações coletivas são externas às consciências individuais, pois não derivam dos indivíduos, mas de sua cooperação, o que é bastante diferente (DURKHEIN, 1970).

Moscovici afasta-se da perspectiva sociológica, presente em Durkhein, ao entender que uma representação social se forma pelos processos de objetivação, isto é, consiste em transplantar para a observação o que era apenas inferência ou símbolo, ou seja, firme inserção de uma ciência na hierarquia de valores e entre as operações realizadas na sociedade, transformando um objeto social em instrumento de que se possa dispor (CERQUEIRA, 2012).

A teoria das representações sociais surge como uma teoria que referencia a dinâmica dos processos sociais para ancorar e objetivar as inovações trazidas para a vida contemporânea, por meio da ciência e da política e que acabam por construir e comunicar realidades. Não se tratam apenas de opiniões, imagens ou atitudes, mas é um ramo do conhecimento que organizam uma dada realidade, estabelecendo uma ordem e criando um código social (CERQUEIRA, 2012).

As representações sociais são reconhecidas como fenômenos psicossociais histórica e culturalmente condicionados e, assim, a pesquisa empírica na área não produz resultados replicáveis ou generalizáveis para outros contextos. Cerqueira (2012) afirma que "as representações sociais são princípios geradores de tomadas de posição ligadas a inserções 
especificas em um conjunto de relações sociais e que organizam os processos simbólicos que intervêm nessas relações”.

A representação permite criar um sistema de interpretação da realidade, regendo as relações entre os indivíduos, tanto em seu meio físico quanto social, determinando, inclusive, as práticas e comportamentos. Ela é, portanto, uma visão global e unitária que "reestrutura a realidade para permitir a integração das características objetivas do objeto" (ABRIC, 1998, p. 27-28). Uma representação é constituída de um conjunto de informações, de crenças, de opiniões e de atitudes a respeito de um dado objeto social. Este conjunto de elementos, se organizado, estrutura-se e se constitui num sistema sociocognitivo de tipo específico.

(ABRIC, 1998, p. 30).

Cada indivíduo percebe o mundo ao seu redor de forma diferente, adapta-se às circunstâncias e cria possibilidades para se inserir no contexto social que o cerca. No intuito de entender a relação do homem com suas representações, surge, em 1961, com o psicólogo francês Moscovici, em seu trabalho A representação social da Psicanálise, a teoria das representações sociais, que remete ao conceito de representação coletiva de Émile Durkheim, esquecido por muito tempo.

Para Moscovici (2003), as representações se constituem em fenômenos da realidade que devem ser descritos e explicados, pois “as representações [...] são fenômenos específicos que estão relacionados com um modo particular de compreender e de se comunicar" - um modo que cria tanto a realidade como o senso comum.

E ainda, para Moscovici (1978),

Toda representação é composta de figuras e de expressões socializadas. Conjuntamente, uma representação social é a organização de imagens e linguagem, por que ela realça e simboliza atos e situações que nos são ou se nos tornam comum. (p.25)

Assim, ao ser considerado um fenômeno cognitivo, que ocorre no nível individual, a imagem e a linguagem ou campo da representação organiza-se a partir da seleção de informações acerca de um dado objeto social. Em seguida, tais informações são contextualizadas dentro de um conjunto de outras informações e imagens, já retidas pelo sujeito, configurando-se em uma nova imagem (GUIMARÃES,2007). Segundo Moscovici (1978) a representação social é:

[...] uma modalidade de conhecimento particular que tem por função a elaboração de comportamentos e a comunicação entre indivíduos. $\mathrm{Na}$ construção de representação social, o indivíduo se constrói na relação com o outro e com o meio social em que faz parte.( p. 26) 
A representação social refere-se, então, ao posicionamento e a localização da consciência subjetiva nos espaços sociais, visando constituir percepções por parte dos indivíduos. Nesse sentido, as representações de um objeto social passam por um processo de formação, entendido como um encadeamento de fenômenos interativos, fruto dos processos sociais no cotidiano do mundo moderno (GUIMARÃES, 2007).

Para Jodelet (2001), "os sistemas de interpretação da realidade são importantes para os estudos da relação do indivíduo com o mundo e com o outro na coletividade". Eles também têm o papel de orientar e organizar condutas e comunicações sociais, de intervir na difusão e assimilação do conhecimento, no desenvolvimento individual e coletivo, na definição de identidades pessoais e coletivas e nas transformações sociais.

Jodelet (2001) aponta que as representações são abordadas concomitantemente como produto e processo de uma atividade de apropriação da realidade exterior ao pensamento e de elaboração psicológica e social da referida realidade. Nesse sentido, faz-se necessário compreender o que define uma representação social, seu modo de geração e funcionamento, bem como seu papel nas relações com a prática dos indivíduos e dos grupos na realidade social (GUIMARÃES, 2007).

Ao formar uma representação social sobre a realidade, de certa forma, a pessoa (re) constrói o seu conhecimento desenhado coletivamente. Assim, inclui em seus próprios sistemas de valores, dependendo de sua história e do contexto social em que estão inseridos, os valores do grupo (GUIMARÃES, 2007). Do ponto de vista de Jodelet (2005), o campo da Educação é um espaço privilegiado para o estudo das relações dialéticas. Segundo a autora, as representações sociais nos diferentes níveis do sistema educativo são:

[...] o nível político, onde são definidas as finalidades e modalidades de organização da formação; o nível da hierarquia institucional, na qual os agentes são encarregados de colocar em práticas essas políticas; e o nível dos usuários do sistema escolar, alunos e pais. Essas representações são reconhecíveis nos contextos institucionais nas práticas concretas através dos discursos dos diferentes agentes e, de maneira histórica, considerando a evolução das políticas educativas, das populações a quais se dirigem com a massificação e a democratização da escola, das posições e das identidades que resultam de parte dos parceiros da relação pedagógica. (JORDELET, 2005, p.42)

Cerqueira (2012), ao falar sobre a importância do estudo das representações sociais na educação, diz que este é uma forma de refletir sobre a pesquisa em educação num contexto de ampliação das possibilidades de leitura e interpretação da realidade, partindo do 
entrelaçamento de todas as instancias do ser humano: razão-emoção, natureza-história, e tantas outras dualizadas historicamente pelo pensamento ocidental. Esse estudo permite questionar e dar voz a discursos pessoais que convivem no mais íntimo do ser, mas que é desvelado no contato com o grupo.

De fato, estudar a representação dos profissionais alvos do presente estudo mostra-se pertinente, uma vez que permite compreender as ideias que tais indivíduos elaboram acerca dos objetos sociais (pessoas, coisas, conceitos, ideias), nas relações produzidas socialmente nos espaços educacionais, no que tange ao uso da informática na Educação. Em resumo, a Teoria da Representação Social possui a vantagem de descrever, mostrar uma realidade, um fenômeno que existe, pois possui grande poder mobilizador e explicativo do fenômeno estudado. Portanto, ajuda a compreender e identificar como a representação social atua na motivação das pessoas, quando elas fazem determinado tipo de escolha.

Santos e Braga (2012) aprofundam o estudo das representações que os professores fazem sobre a informática, em especial, sobre o computador, na Educação Infantil. Os autores tomaram por base Moscovici (1978), para quem "as representações sociais dos indivíduos têm uma grande função simbólica e um enorme poder de construção da realidade objetiva”. Compreender as representações dos professores ajuda a entender o que está envolvido no potencial real de inserção da informática no referido modal educacional.

Com o uso da Técnica do Grupo Nominal, os pesquisadores Santos e Braga (2012) procuraram entender algumas representações negativas ou equivocadas que influenciam ou resultam em intervenções pedagógicas problemáticas, no que se refere à consideração do potencial pedagógico da tecnologia. Foram levantadas dez proposições, divididas em dois eixos, com cinco positivas e cinco negativas, que compuseram um questionário com fins de elucidar posicionamentos acerca do uso da informática na Educação Infantil.

Os posicionamentos surgiram no contexto de uma investigação de iniciação científica, desenvolvida no Laboratório Ábaco da Faculdade de Educação (FE) da Universidade de Brasília (UnB). No resultado da investigação, foram elencados cinco indicadores positivos referentes a integração de situações informatizadas no trabalho com crianças pequenas:

O computador diverte as crianças e torna as aulas mais interessantes.

A informática educativa refina o raciocino das crianças pequenas.

O computador exige uma nova postura por parte do professor, o que é sempre bom.

É preciso reinventar a organização do trabalho pedagógico para uma correta inserção do computador. Isto é muito estimulante para o professor. 
A informática educativa reinventa a sala de aula e uma nova relação educativa é instaurada.

Entretanto, a pesquisa identificou posicionamentos negativos que influenciam a aceitação e o uso de recursos informatizados na educação infantil, quais sejam:

$\checkmark \quad$ É muito complicado fazer uso da informática na Educação de modo sério. Acaba ficando tudo muito enrolado, sobretudo, para o professor.

A informática demanda muito tempo do professor.

A informática educativa é um engodo: muitas promessas e poucas realizações.

O computador é constrangedor porque as crianças não precisam de professor para ensinar nada. Parece que elas nascem sabendo usar a informática.

$\checkmark \quad$ Acho prematuro a utilização do computador na escola de Educação Infantil, onde a criança necessita de outras bases para iniciar o Ensino Fundamental.

$\mathrm{Na}$ análise dos posicionamentos da pesquisa, é possível observar que a temática da inserção da informática é algo conflitante: ao mesmo tempo em que os docentes são a favor, apresentam representações que simulam certa resistência à ideia do trabalho com a informática. Entretanto, existem afirmativas intrigantes, conforme se seguem:

Unanimidade - tensão entre o professor e o recurso tecnológico; devido à falta de conhecimento, há um desconforto, pois não sabem manipular o recurso, o que traz uma desorganização à aula. Esta proposição de mediar o conhecimento é algo não muito aceito dentro das bases tradicionais de ensino.

$>$ A informática promete muito, mas com poucas realizações. Devido ao enfoque de que a tecnologia resolveria os problemas da escola, muitos docentes, por não se atentarem à mudança, acreditam que a informática não mudou nada.

A informática ainda constrange o professor. A pesquisa referida aponta que alguns docentes sentem-se incomodados pelas crianças estarem mais bem relacionadas com a informática. Estes, por serem os "professores", sentem-se afrontados pela postura das crianças.

Nessas afirmativas dos professores, ora escritas, também destacam que, mesmo com o avanço da informatização das escolas de Educação Infantil, as relações docentes com a informática tem sido conflituosas decorrentes da falta de formação, o que tem levantado problemas de ordem didática que transpõem os limites da atuação do professor em sala de aula, contribuindo na criação de representações vinculadas a resistências quanto ao uso dos recursos. Outra observação importante é que as políticas governamentais não são efetivas quase sempre incluem compra de equipamentos e nunca focam na questão da formação para 
operar os equipamentos com fins pedagógicos, ocasionando desconforto, pois algumas escolas têm equipamentos, mas não possuem professores capacitados para utilizá-los.

Atualmente, percebe-se que a inserção de recursos informatizados na escola é comum. Entretanto, a chegada destes requer do professor um novo entendimento sobre as relações intrínsecas ocorridas no processo de ensino aprendizagem - o que acarretou em uma nova representação sobre a função do docente. Barreto (2002) destaca que o poder dos professores tornou-se vulnerável devido aos questionamentos que alguns setores da sociedade fizeram quanto à relevância ou não de tal profissional, diante das diversas possibilidades de uso de tais suportes tecnológicos. O autor menciona ainda que os docentes deixaram de ser concebidos como únicos elementos dotados de sabedoria e capazes de ensinar. Aliás, a sabedoria dos professores passou a ser contestada pelos alunos - consequência, entre outros motivos, da facilidade que os jovens de hoje possuem em acessar, por meio dos computadores, diferentes informações. Este fenômeno é fonte de resistência, pois alguns docentes sentem-se incomodados com a nova posição que a informática tem ocupado, cada vez mais cedo, na escola e na vida dos alunos. Para a compreensão das representações docentes, faz-se importante identificar as representações resultantes do trato com a linguagem digital no trabalho com as crianças pequenas. 


\section{MODELO TEÓRICO SOBRE ACEITAÇÃO E USO DE TECNOLOGIA ( UTAUT)}

A temática da aceitação e o uso de recursos informatizados ou de tecnologias não é matéria presente somente na Educação. Pesquisadores e profissionais na área de Ciências da Computação, Sistema de Informação, entre outros, desenvolvem pesquisas sobre o fato dos indivíduos aceitarem ou rejeitarem determinada tecnologia (VENKATESH; MORRIS DAVIS, 2003; STRAUB; KEIL; BRENNAN, 1997). As mais diversas atividades, de todas as esferas sociais, demandam o uso da informática. Entretanto, há uma quantidade considerável de pessoas que não a aceitam ou não a utilizam por concepções e atitudes diversas.

$\mathrm{Na}$ escola de Educação Infantil, é possível observar que os objetivos, papéis e metodologias vêm recebendo influência direta de recursos informatizados que têm afetado as relações educativas. Tão importante quanto responder às demandas atuais da sociedade informacional, é preciso, então, entender como os professores percebem a informática e a relacionam com o ensino.

Silva (2006) destaca a importância de não se ter apenas um olhar técnico - direcionar as atenções aos requisitos oferecidos pela tecnologia - para entender sua utilização, mas, sim, buscar compreender o comportamento de quem irá utilizá-la. Tal fato aponta que, mesmo falando de tecnologia, atentar-se às representações do homem ou a forma como este interpreta o seu uso, poderá influenciar no modo como se aceita determinada tecnologia. Estudiosos propuseram testes e métodos com a finalidade de avaliar o uso e o comportamento dos usuários no que tange à relação da aceitação das tecnologias - são os chamados modelos teóricos, com destaque para o modelo UTAUT - Unified Theory of Acceptance and Use of Technology.

Este modelo surgiu com o intuito de estruturar uma amostra que unificasse os principais estudos da área de aceitação da tecnologia, Venkatesh; Morris; Davis e Davis (2003) desenvolveram a Teoria Unificada de Aceitação e Uso da Tecnologia (UTAUT), através da análise e comparação de oito modelos relevantes: a Teoria da Ação Racionalizada (TRA); o Modelo de Aceitação da Tecnologia (TAM); o Modelo Motivacional (MM); a Teoria do Comportamento Planejado (TPB); a combinação entre a TAM e a TPB; o Modelo de Utilização do PC (MPCU); a Teoria da Difusão da Inovação (IDT) e a Teoria Social Cognitiva (SCT). Venkatesh et al. (2003) destacam que a escolha desses modelos deveu-se ao fato de eles já terem sido amplamente testados em ambientes da TI e aprovados pela comunidade acadêmica, visto que são referência em periódicos internacionais. 
Com o intuito de unificar esses modelos e gerar um ainda mais completo, que abrangesse os principais construtos relacionados à aceitação da TI, Venkatesh et al (2003) desenvolveram a Teoria Unificada de Aceitação e Uso da Tecnologia, contribuindo significativamente para os estudos na área dos Sistemas de Informação (RAAIJ; SCHEPERS, 2008).

Dessa forma, Venkatesh et al (2003) realizaram uma comparação empírica com os oito modelos, conduzindo um estudo longitudinal com indivíduos de quatro organizações que estavam introduzindo uma nova tecnologia em seu ambiente de trabalho. O questionário utilizado baseou-se em variáveis dos construtos de todos os modelos citados, as quais haviam sido validadas em estudos organizacionais e tecnológicos.

Essa teoria gerou um novo modelo integrado, que apresenta quatro construtos determinantes da intenção e do uso da TI e quatro moderadores:

Figura 1 - Teoria Unificada de Aceitação e uso de tecnologia UTAUT

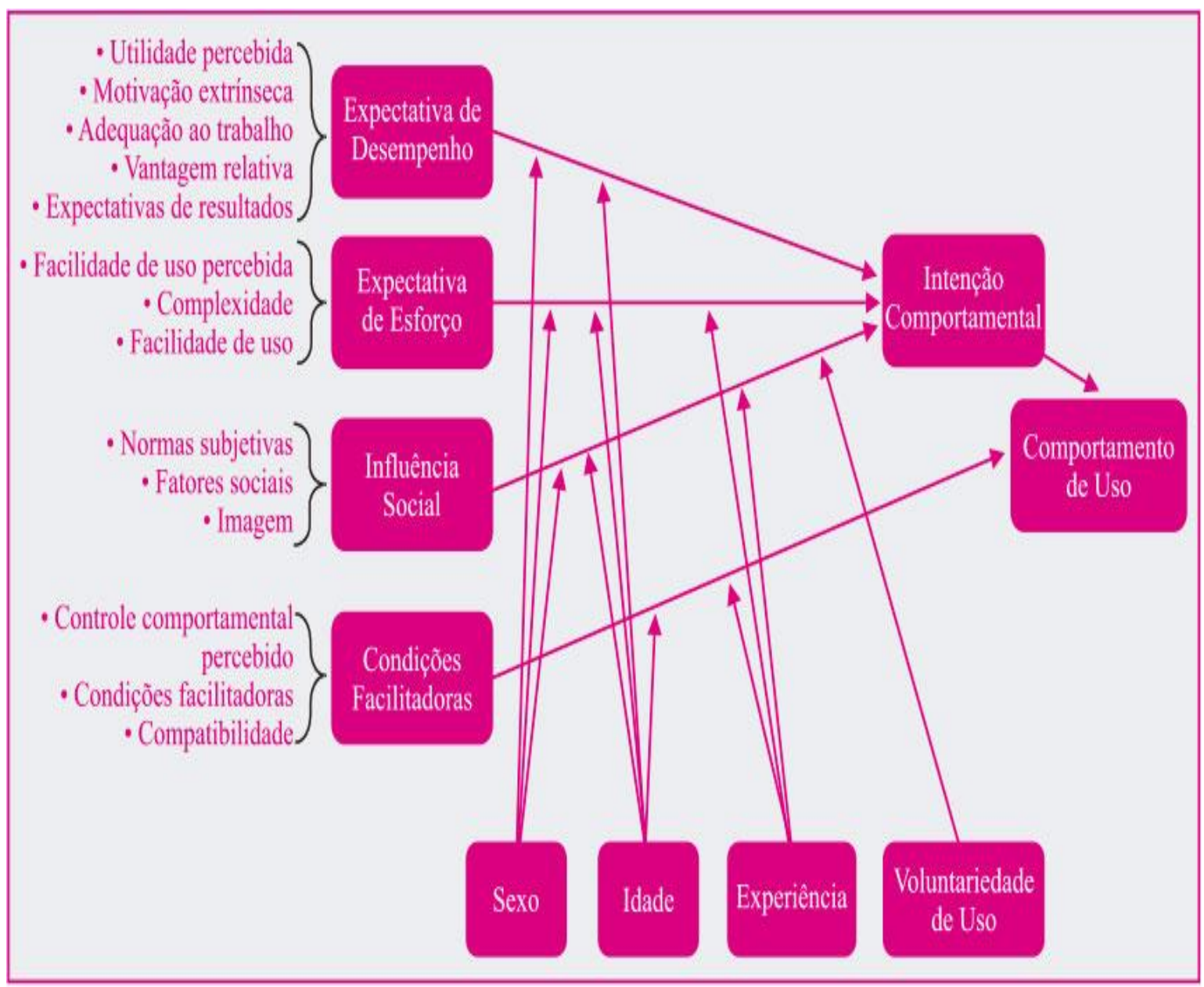

Fonte: Adaptado de Venkatesh et al. $(2003$, p.447). 
O construto da expectativa de performance está baseado em cinco modelos: TAM/TAM2/combinação entre a TAM e TPB; MM; MPCU; IDT e SCT. A partir da compilação destes, Venkatesh et al (2003, p. 447) definiram a expectativa de performance como o grau em que o indivíduo acredita que usando o sistema ele terá ganhos em relação ao seu desempenho no trabalho.

A expectativa de esforço foi desenvolvida sobre três modelos bastante semelhantes em definições e medidas de escala: TAM/TAM2; MPCU e IDT. Através dela, o indivíduo relaciona o grau de facilidade associado ao uso do sistema (VENKATESH et al, 2003, p.450).

A influência social é definida como o grau de percepção do indivíduo em relação aos demais quanto à crença destes para com a necessidade de uma nova tecnologia ser usada ou não (VENKATESH et al, 2003, p. 451). Esse construto é importante quando o uso da tecnologia é voluntário, entretanto ele deixa de ser significativo quando o uso é mandatório. Baseia-se nos modelos de norma subjetiva (TRA, TAM2, TPB/DTPB e a combinação TAM/TPB), nos de fatores sociais (MPCU) e nos de imagem (IDT).

O construto denominado condições facilitadoras é descrito como o grau pelo qual o indivíduo acredita que existe uma infraestrutura organizacional e técnica para suportar o uso do sistema (VENKATESH et al, 2003, p. 453). Segundo os autores, essa definição concentra conceitos personificados por três diferentes construtos: controle percebido do comportamento (TPB/DTPB, combinação TAM/TPB), condições facilitadoras (MPCU) e compatibilidade (IDT). Há também os quatro construtos moderadores da intenção e uso da TI: o gênero, a idade, a experiência do indivíduo e a voluntariedade do uso (o grau pelo qual o uso da tecnologia é voluntário ou livre, ou seja, não obrigatório).

Identificados os construtos do modelo, Venkatesh et al (2003) realizaram estudos empíricos para validá-los. O estudo foi aplicado em duas organizações e os resultados confirmaram a existência de três determinantes diretos da intenção de uso e dois determinantes diretos do uso, além da influência das quatro variáveis moderadoras. Os autores identificaram que o modelo explica $70 \%$ da variância da intenção de uso. Dessa forma, Venkatesh et al (2003) acreditam que o modelo seja uma ferramenta útil para os gestores que necessitam avaliar a probabilidade de sucesso de uma nova tecnologia e auxilia na compreensão dos fatores determinantes da aceitação do uso, bem como no desenho de intervenções nas tecnologias.

Sendo assim, o desenvolvimento do UTAUT contribuiu para o avanço da pesquisa sobre a aceitação individual da TI, unificando as perspectivas teóricas mais difundidas na literatura e incorporando moderadores para controlar as influências do contexto 
organizacional, a experiência do usuário e as características demográficas (KAUFMANN, 2005). O modelo é uma ferramenta que auxilia no entendimento dos direcionadores da aceitação de uso, pois permite identificar intervenções a fim de facilitar a aceitação de novos usuários de tecnologias, considerando representações que influenciam a adoção de inovações.

Na pesquisa a opção pelo aprofundamento no entendimento do UTAUT é justificada considerando que está é uma das questões para a compreensão que além de fatores didáticos podem ser encontrados fatores ligados ao recurso tecnológico, ou envolvidos na configuração deste para o uso com as crianças desta faixa etária, tendo em vista que as fragilidades de uso tendem a incitar uma rejeição para determinida TDCIE.

O UTAUT ainda fornece dados para a compreensão que a aceitação da TDCIE é possível desde que sejam adotadas algumas estratégias ligadas as condições facilitadoras de uso como a expectativa de desempenho e a expectativa de esforço. 


\section{METODOLOGIA DA PESQUISA}

Nascimento (2012, p.11) refere-se à metodologia como a aplicação do método para a aquisição de conhecimento e de como fazer ciência, proporcionando-se caminhos, ferramentas e procedimentos, ao destacar que: “A metodologia proporciona flexibilidade aos caminhos e alternativas na resolução dos problemas para os quais procuramos resultados apropriados em relação aos propósitos pretendidos”.

A presente pesquisa utilizou-se de pressupostos da pesquisa qualitativa, através do método da pesquisa fenomenológica, que trabalha com os significados das experiências de vida sobre uma determinada concepção ou fenômeno, explorando a estrutura da consciência humana (SATO, 2001). Nesse método de pesquisa, os pesquisadores buscam a estrutura invariável ou essência, com elementos externos e internos alocados em determinados pilares, a saber: memória, imagens, significações e vivências que compõem a subjetividade. A Fenomenologia ressalta a ideia de que o mundo é criado pela consciência - o que implica no reconhecimento da importância do sujeito no processo da construção do conhecimento e valoriza suas interações e os fenômenos envolvidos. O método fenomenológico é descritivo e analisa as percepções inerentes à essência dos fenômenos e a subjetividade transcendental, pois as essências só existem na consciência (MOREIRA, 2004).

Nesse sentido, segundo Creswell (2010, p.26),

a pesquisa qualitativa é um meio para explorar e para entender o significado que os indivíduos ou os grupos atribuem a um problema social ou humano. $\mathrm{O}$ processo de pesquisa envolve as questões e os procedimentos que emergem, os dados tipicamente coletados no ambiente do participante, a análise dos dados indutivamente construída a partir das particularidades para os temas gerais e as interpretações feitas pelo pesquisador acerca do significado dos dados.

A pesquisa qualitativa se preocupa com um nível de realidade que não pode ser quantificado, ou seja, foca seus estudos no universo de significados, motivos, aspirações, crenças, valores e atitudes, o que corresponde a um espaço mais profundo das relações, dos processos e dos fenômenos que não podem ser reduzidos à operacionalização de variáveis (MINAYO, 1994).

Segundo Moreira (2004), as principais características da pesquisa qualitativa são: o foco dado à interpretação dos dados ao invés de sua quantificação; a ênfase na subjetividade, em vez da objetividade; a flexibilidade permitida no processo de conduzir a pesquisa; e, a 
orientação para o processo e não para o resultado, ou seja, a ênfase está no entendimento e não em um objetivo predeterminado.

\subsection{Abordagem Metodológica}

A abordagem metodológica escolhida foi o estudo de caso. Conforme afirma Yin (2005, p. 19), o estudo de caso "serve para responder questionamentos que o pesquisador não tem muito controle sobre o fenômeno estudado. Este método é útil quando o fenômeno a ser estudado é amplo e complexo e não pode ser estudado fora do contexto onde ocorre naturalmente." Para o autor, o estudo de caso investiga um fenômeno contemporâneo partindo do seu contexto real, fazendo uso de múltiplas fontes e evidências.

Sendo assim, na presente pesquisa, a utilização do método de estudo de caso é fundamental, uma vez que Gil (2008) enfatiza que essa abordagem metodológica vem sendo utilizada com frequência, cada vez maior, pelos pesquisadores sociais, servindo para diferentes propósitos, tais como:

a. explorar situações da vida real cujos limites não estão claramente definidos;

b. descrever a situação do contexto em que é feita determinada investigação; e

c. explicar as variáveis causais de determinado fenômeno em situações muito complexas que não possibilitam a utilização de levantamentos e experimento.

\subsection{Instrumentos e procedimentos para a construção de dados}

\subsubsection{Questionário}

É uma técnica de investigação social composta por um conjunto de questões que são submetidas a pessoas com o propósito de obter informações sobre conhecimentos, crenças, sentimentos, valores, interesses, expectativas, aspirações, temores, comportamento presente ou passado (GIL, 2012).

O questionário foi elaborado com questões mistas com o intuito de traçar um perfil das docentes participantes da pesquisa, seu roteiro encontra-se em Apêndice. Foram elaboradas questões sobre a idade, gênero, formação acadêmica, experiência em docência, periodicidade de uso da informática, sites mais utilizados, finalidade de uso e duas questões diretas com afirmações para que a docente assinalasse o(s) pressuposto(s) e a(s) concepção(ções) que 
justificam a inserção da informática nas práticas educativas. Ele foi entregue antes do início da entrevista individualmente a cada entrevistado. Os participantes demoraram entre 10 e 15 minutos para responder as questões. E ao terminarem de responder as perguntas, as docentes eram entrevistadas, tendo em vista que o tema permanecia em suas mentes e mais facilmente afloravam respostas sobre suas representações.

\title{
5.2.2 Entrevista semiestruturada
}

A opção pela entrevista semiestruturada justifica-se pelo fato de possibilitar a coleta de dados frente a frente com o sujeito no ambiente em que os fenômenos ocorrem. Para Ludke e André (1986), a grande vantagem da entrevista sobre outras técnicas é que ela permite a captação imediata e corrente da informação desejada com qualquer tipo de informante e sobre os mais variados tópicos.

Corroborando a importância da entrevista semiestruturada, Minayo (1994) afirma:

\begin{abstract}
A entrevista é o procedimento mais usual no trabalho de campo. Através dela, o pesquisador busca obter informes contidos na fala dos atores sociais. Ela não significa uma conversa despretensiosa e neutra, uma vez que se insere como meio de coleta dos fatos relatados pelos atores [...]. Nesse sentido, a entrevista, um termo bastante genérico, está sendo por nós entendida como uma conversa a dois com propósitos bem definidos. Num primeiro nível, essa técnica se caracteriza por uma comunicação verbal que reforça a importância da linguagem e do significado da fala. Já, num outro nível, serve como um meio de coleta de informações sobre um determinado tema científico. (MINAYO, 2002, p. 57)
\end{abstract}

Com o objetivo de compreender, por meio das representações dos professores, as demandas enfrentadas na inserção de recursos informatizados na escola, a entrevista intenta favorecer a construção de saberes variados ou representações diversas, que afetam as relações entre o fenômeno e os sujeitos da pesquisa. Para tanto, as entrevistas tiveram um roteiro prédefinido, que está disponível no Apêndice, dividido em blocos temáticos, extraídos de temas que permeiam os objetivos específicos de pesquisa. As entrevistas foram gravadas em áudio, com duração de sessenta minutos, foram organizadas por um roteiro de tópicos definido, disponível apenas a pesquisadora. Os tópicos versavam sobre a inserção dos recursos na escola, como estes influenciam a aula, os pressupostos e concepções de uso que justificam a adesão pelo uso da informática, as vantagens percebidas, as desvantagens, problemas enfrentados durante o uso, como foram superadas as dificuldades e se o uso influenciou o modo de encarar o trabalho com o computador em atividades destinadas às crianças pequenas. 


\subsubsection{Roda de Conversa}

A roda de conversa consiste em um método de participação coletiva de debates acerca de uma temática, através da criação de espaços de diálogo, nos quais os sujeitos podem se expressar e, sobretudo, escutar os outros e a si mesmos. Tem como principal objetivo motivar a construção da autonomia dos sujeitos por meio da problematização, da socialização de saberes e da reflexão voltada para a ação. Envolve, portanto, um conjunto de trocas de experiências, conversas, discussão e divulgação de conhecimentos entre os envolvidos nesta metodologia (NASCIMENTO; SILVA, 2009).

Para Figueiredo e Queiroz (2012), a roda de conversa prioriza discussões em torno de uma temática (selecionada de acordo com os objetivos da pesquisa) e, no processo dialógico, as pessoas podem apresentar suas elaborações, mesmo contraditórias. Na roda de conversa, cada pessoa instiga a outra a falar, sendo possível se posicionar e ouvir o posicionamento do outro.

Segundo Afonso e Abade (2008), a roda de conversa é utilizada nas metodologias participativas, e tem como objetivo a constituição de um espaço em que seus participantes reflitam acerca do cotidiano, ou seja, de sua relação com o mundo, com o trabalho, com o projeto de vida (FIGUEIREDO; QUEIROZ, 2012).

A roda de conversa, nesta pesquisa, foi utilizada para identificar as concepções e atitudes das docentes referente ao uso da informática com as crianças pequenas. Com base nas compilações realizadas durante as entrevistas e o questionário, as rodas de conversa intentaram clarificar com figuras e palavras associadas as imagens que representavam melhor os comportamentos positivos e negativos frente ao desafio de inserir e utilizar as TDCIE.A identificação das concepções e atitudes intentou compreender o modelo UTAUT e apontar possíveis tentativas de elucidação do fatores presentes no imaginário da docente, mas muito reais que influenciam a adoção e uso da informática. (roteiro em Apêndice)

A roda de conversa aconteceu em uma coordenação coletiva com duração de uma hora e vinte minutos, gravada em áudio, com o auxílio do Audacity (programa que permite gravar e editar diferentes tipos de áudios, instalado no notebook).

$\mathrm{Na}$ roda de conversa, as docentes tiveram um tempo livre para refletirem sobre suas representações, tendo em vista que estas foram convidadas a escolher individualmente entre vinte figuras selecionadas previamente, com base nas falas sobre a informática apresentadas durante a compilação do questionário e da entrevista. As imagens estavam impressas a docente escolhia a que representava uma atitude positiva e expressava em uma palavra ou 
frase o que está imagem lhe remetia para as outras docentes, ao final tínhamos um painel que evidenciava o agrupamento de todas as imagens positivas do grupo de professoras da escola.

Para analisar as atitudes e concepções negativas utilizou-se a mesma dinâmica, de imagens e frases, sendo que as imagens negativas apresentadas eram um conjunto das principais categorias negativas evidenciadas durante a entrevista e o questionário e complementadas com pesquisas teóricas que alicerçam o presente estudo.

\subsection{Análise dos Dados}

A análise dos dados da presente pesquisa foi realizada com base no método de análise de conteúdo, de acordo com Bardin (2009). Esse método abrange as iniciativas de explicitação, sistematização e expressão do conteúdo de mensagens, com a finalidade de se efetuarem deduções lógicas e justificadas a respeito da origem das referidas mensagens (quem as emitiu, em que contexto e/ou quais efeitos se pretende causar por meio delas).

A análise de conteúdo constitui:

Um conjunto de técnicas de análise de comunicação visando a obter, por procedimentos sistemáticos e objetivos de descrição do conteúdo das mensagens, indicadores (quantitativos ou não) que permitam a inferência de conhecimentos relativos às condições de produção/recepção destas mensagens. (BARDIN, 2009, p.42)

Partindo do questionário, das entrevistas e da roda de conversa, foram emergindo temas vinculados às representações das professoras em relação à inserção da informática na Educação Infantil, tendo em vista a proposta de compreender até que ponto tais representações influenciam diretamente no posicionamento e na adoção de recursos informatizados pelas docentes. 


\section{AS PROFESSORAS PESQUISADAS E A TECNOLOGIA DIGITAL}

As participantes da pesquisa são professoras em regência de classe, que atuam no Centro de Educação Infantil de Santa Maria, vinculadas à Coordenação Regional de Ensino de Santa Maria, Distrito Federal. A escola possui laboratório de informática, com 16 computadores, e toda infraestrutura para o atendimento de crianças entre quatro e cinco anos de idade, com parque infantil, brinquedoteca, refeitório, cadeiras e mesas adaptadas. Não possui biblioteca, mas nas salas há espaços para livros e locais para leitura.

Todas as professoras em regência de classe foram convidadas para participarem da pesquisa, mas somente 06 (seis) aceitaram contribuir com suas respostas. Tem-se, então, o perfil acadêmico e tecnológico de cada uma, conforme o questionário respondido:

Docente A: 28 anos; formada em Pedagogia pela Faculdade JK em 2010; especialista em Docência da Educação Infantil pela Faculdade Cruzeiro do Sul, em 2013; 05 (cinco) anos que atua em docência, destes, são três anos na educação infantil, iniciando pela creche, em 2014 está com alunos de 04 (quatro) anos de idade; possui computador, smartphone, tablet e notebook; tempo de conexão por dia acima de 05 horas.

Docente B: 45 anos; formada em Pedagogia pela Universidade de Brasília, participante do Curso de Pedagogia para Professores em Início de Escolarização (PIE/SEEDF) em 2006; 14 (catorze) anos de atuação em docência, sendo 9 (nove) na Educação Infantil, passou pela coordenação pedagógica e apoio a direção, em 2014 está com turma de alunos de 05 (cinco) anos de idade; possui computador, notebook e celular; tempo de conexão até uma hora por dia.

Docente C: 38 anos, formada em Pedagogia pela Unopar (Universidade do Norte do Paraná) em 2009; especialista em Psicopedagogia Escolar em 2013; 06 (seis) anos que atua em docência, sendo 02 (dois) em educação infantil, em 2014, está com turma de alunos de 04 (quatro) anos de idade; possui computador, smartphone, notebook; tempo de conexão até 03 (três) horas por dia.

Docente D: 42 anos, formada em Pedagogia pelo Grupo Educacional FAESB, em 2012; cursando especialização em Psicopedagogia, à distância; 02 (dois) anos de atuação como docente, sempre na Educação Infantil, em 2014 está com turma de alunos de 05 (cinco) anos de idade; possui computador, tablet, smartphone e notebook; tempo de conexão até 05 (cinco) horas por dia.

Docente E: 34 anos, formada em Letras e com complementação em Pedagogia em 2011; cursando especialização em Docência da Educação Infantil, à distância; 08 (oito) anos de docência, sendo 02 (dois) na educação Infantil, em 2014 está com turma de alunos de 05 (cinco) anos de idade; possui computador, smartphone, notebook; tempo de conexão até 03 (três) horas por dia .

Docente F: 39 anos, formada em Pedagogia pela Universidade de Brasília, em 2005; 1; 12 (doze) anos de docência, sendo 05 (cinco) em educação Infantil, em 2014 está com turma de alunos de 04 (quatro) anos de idade; 
possui computador, notebook e celular; tempo de conexão até uma hora por dia.

Ao iniciar a entrevista, após a análise do questionário, a primeira pergunta foi: Comece falando sobre o uso que você faz da tecnologia em sua vida. Com base nas falas das docentes percebemos alguns pontos interessantes que ajudam na definição do perfil das professoras pesquisadas:

Docente A : Gosto de me conectar em casa e na escola, navego onde quero e sempre estou em sites e páginas que trazem ideias para a educação infantil, procuro lembrancinhas, atividades e notícias sobre o PNAIC. Tudo sobre a Educação, mas tenho meu momento de distração, uso muito o facebook e whatssap para conversas e compartilhamento. Outra coisa que fiz foi uma página para compartilhar as fotos dos alunos com os pais, daí eles sabem o que as crianças fazem aqui na escola.

Docente B: não gosto de exposição, mal tenho celular, tenho facebook, mas não uso, não sou chegada à tecnologia. ... Isso é porque não sei usar muito bem acho tudo complicado.

Docente C: Uso muito pouco, somente o Facebook, tenho dificuldades com as máquinas tecnológicas e não tenho tempo, na escola são 26 alunos, em casa tenho filhos e o computador sempre tá ocupado, daí não tenho interesse e tempo. Mas sou obrigada a usar para fazer os relatórios, também só sei digitar mesmo.

Docente D: Sou fã da tecnologia, em qualquer hora e lugar, gosto de redes sociais, postar, comentar, compartilhar e curtir. Sempre pesquiso jogos e atividades para meus alunos, Lembrancinhas e sigo páginas educativas com temática sobre crianças, fico horas na internet, navego em tudo, gosto de distrair e vejo que este pode ser um meio de melhorar a aprendizagem com meus alunos, pois vejo tanta coisa para os pequenos.

Docente E: Uso sempre que posso para acessar emails, redes sociais, páginas educativas e blogs, fazer os relatórios, não domino muito, tenho dificuldade principalmente com os programas mais sofisticados, mas gosto de estar por dentro do que acontece e me sentir incluída no mundo digital, passei anos para conhecer o que conheço sobre as tecnologias e vou aperfeiçoando o uso com o passar do tempo. Na escola busco usar o laboratório com os alunos, mas sempre peço ajuda de alguém.

Docente F: Acho complicado falar viu...tenho pouco domínio, acho bom ver meus alunos mexendo e usando... meu filho de 03 anos mexe em tudo no meu celular, mas eu tô por fora viu... uso mal o facebook e muito pouco entendo de tecnologia. Acho bonito, legal, mas sinto dificuldades e não tenho tempo de ficar tentando. Só uso o Word para digitar os relatórios e mais nada... tenho que pedir ajuda em tudo.

Analisando os conteúdos das falas, pode-se inferir que as docentes A, D, E apresentam certa familiaridade com as tecnologias digitais, têm tempo de acesso mais prolongado e estão sempre interagindo com o uso das redes sociais. Entende-se que estas dominam o uso dos recursos como passatempo e sempre que possível pesquisam formas de integrar esses recursos a sua prática pedagógica. 
As docentes B e C são honestas em revelar que possuem algumas dificuldades em usar os recursos tecnológicos. Como justificativa elas se utilizam de uma gama de expressões para justificar: "Não gosto de exposição, acho complicado", "não tenho interesse e tempo". Tais expressões aparentam e influenciam as concepções e atitudes com respeito a adoção ou não de tecnologias. Segundo o modelo de aceitação e uso de tecnologia UTAUT, a familiaridade com os recursos corrobora na aceitação e adoção de determinada tecnologia. O comportamento quanto à facilidade e utilidade faz com que o sujeito apresente uma predisposição a aderir ao uso.

A docente $\mathrm{E}$ assume que possui dificuldade de uso, mas pela necessidade de sentir-se incluído, procura formas de sanar as dificuldades aderindo ao uso, como possibilidade de auxiliá-lo a familiarizar-se com as tecnologias, e usá-las com os alunos.

Considerando as análises, este é um panorama comum nas escolas, pois temos professoras que usam as tecnologias, mas não as dominam, e temos outras que usam como passatempo, mas apresentam dificuldades em encontrar um uso pedagógico para as aplicações. Cuban (2001) diz que as professoras carecem de uma compreensão maior de como as tecnologias podem ser integradas a sala de aula, funcionando em harmonia com o currículo. Vê-se que a professora se apropria da tecnologia, mas não sabe como adequá-la pedagogicamente.

Ferreira (2003) diz que o desenvolvimento profissional da professora engloba a formação inicial e contínua, é um processo que permeia toda sua vida, ela aprende e ensina todos os dias. Está focalizada no processo e acontece num movimento permanente de dentro para fora, ou seja, teoria e prática se relacionam e atuam nas práticas pedagógicas.

Entretanto, percebe-se que a formação para a docência é, nesta pesquisa, o ponto de partida para a construção das representações que influenciam o uso da informática. Libâneo (1998) destaca que as resistências ao uso da informática existem, pois não são trabalhadas nos processos de formação inicial e contínua do professor. O autor afirma que isso poderia ocorrer a partir da integração das novas tecnologias aos currículos, do desenvolvimento de habilidades e da formação de atitudes favoráveis ao emprego dessas tecnologias.

No questionamento seguinte, foi solicitado que o docente falasse em poucas palavras sobre como ele interpreta a implantação do laboratório de informática na escola de educação infantil e se ele sente-se capacitado para o uso:

Docente A: Fiquei impaciente e esperançosa, ...aguardei o dia da instalação se bem que cansei de esperar... esperar o prazo de dois anos para ver tudo funcionando foi demais... depois quando tudo foi instalado, nova dor de 
cabeça, o programa da máquina era o Linux e ninguém sabia usar. Foi desmotivador ver tantos micros parados por tanto tempo sem poder utilizar... Não estou capacitada ainda, preciso de mais formação, estou fazendo o curso do ProInfo, mas pouco aprendi até o momento que seja realmente útil na minha prática.

Docente B: (Posso falar que me senti ameaçada)... Sério fiquei bolada entendia que o computador podia a qualquer momento tirar o olhar das crianças de meu trabalho e voltar-se para aquela máquina insuportável que não consigo dominar até hoje. Não participei de capacitação.

Docente C: Apreensão... entendo que computadores são bons, mas a espera para a montagem e a capacitação foram falhas, não vi uso prático que impactasse a minha docência. Participei do Proinfo, gostei do curso aprendi algumas dicas para usar o computador no geral, mas pouco relacionado à prática.

Docente D: Lá vem novidade, achei empolgante, como sempre tive acesso às tecnologias, pensei em como poderia utilizar para melhorar minha sala de aula. Quanto ao se estou preparada posso dizer que caminho para a preparação, fiz o ProInfo e senti que faltou um enfoque na educação infantil específico, isso poderia ajudar a lidar melhor com essa tecnologia.

Docente E: Achei inovador, pois a educação infantil sempre ficou em último plano. Vi que pouco acrescentou a prática, não fiz o curso ainda, mas pretendo em breve, me capacitar, o que acontece é que falam tão mal do curso que fico com preguiça de perder meu tempo.

Docente F: Desânimo total, só vi gasto excessivo e uma espera interminável, de útil até o momento não presenciei nada. Não fiz curso não tenho tempo e não gosto de tecnologias.

Os docentes apresentaram percepção de que a chegada do laboratório causou uma inquietação, que despertou sentimentos diversos como impaciência, esperança, ameaça, euforia, inovação e desânimo. As representações sociais estão ligadas às experiências, à cultura assimilada durante a vida, à linguagem que utiliza nas relações sociais e à história pessoal e do grupo a que pertence. As representações são influenciadas pelo meio onde se situam os acontecimentos que interagem com os comportamentos sociais.

Segundo Carneiro (2002), as representações sociais sobre o uso da informática atuam como motores de favorecimento ou resistência à utilização e não podem ser ignorados na inserção de mudanças, principalmente no contexto educacional. Percebe-se que quando o docente apresenta uma familiaridade com os recursos informatizados, ele aparenta ter mais consciência de sua aplicação e seu comportamento para a adesão é mais positivo, vê-se isso nos docentes A, D e E.

Ao indagar-se sobre a formação oferecida para uso ou adequação das tecnologias no trabalho com as crianças nesta fase escolar, foi solicitado que as professoras falassem sobre sua formação para o uso da tecnologia, considerando a graduação e não se esquecendo da formação continuada. Estas relataram que tiveram alguma disciplina em que estudaram os 
pressupostos teóricos de inserção da tecnologia, destacando sua importância, mas pouco relacionada ao uso concreto com as crianças. A docente B destacou:

Tive a oportunidade de cursar a uma disciplina acho que falou sobre a importância da tecnologia, mas senti falta de um aparato prático como dicas de sites e outros pontos que acho serem essenciais para inserir pedagogicamente a tecnologia na escola...

Quanto a formação continuada, as professoras A, C e D participaram do Programa Nacional de Formação Continuada em Tecnologia Educacional (ProInfo Integrado), cursando o Educando com Tecnologias, ministrado pelo Núcleo de Tecnologia Educacional (NTE) de Santa Maria, com 180h (cento e oitenta) divididas em aulas presenciais e a distância. Indagadas sobre se neste curso encontraram a ligação com a almejada prática, as docentes responderam que o curso é muito bom, é extenso e poderia ser mais voltado para a Educação Infantil. A docente D claramente explicou:

O curso foi um divisor de águas em minha prática, como não conhecia o Linux educacional, entender e conhecer suas possibilidades fez com que eu mudasse a ideia sobre o programa do MEC e ofereceu a oportunidade de conhecer joguinhos e passatempo que aplico até hoje com meus alunos. Mas em contrapartida fiquei triste, pois este tema foi tratado em apenas 02 encontros e sinto que poderia ter tido um curso mais específico para os professores da Educação infantil.

Ao serem perguntadas sobre quais as atividades práticas que aprenderam no curso, a docente A destacou algumas das atividades práticas que foram citadas pelas colegas como:

A criação de blogs, a postagem de fotos, a consulta à internet em sites pedagógicos de apoio ao trabalho em sala e a possibilidade de utilização do conteúdo para o ensino e aprendizagem da criança pequena. O Linux também me instigou a entender, pois não saí muito familiarizada, gosto do Windows e não consegui associar muito o uso.

Infere-se que uma proposta de formação, adequada à realidade, necessita fazer com que a preparação da professora para o uso das tecnologias digitais de comunicação e expressão perpasse toda a formação, devendo se desenvolver pautada na interdisciplinaridade, na relação teoria-prática, na interação universidade-escola e conteúdo específico - conteúdo pedagógico etc.

$\mathrm{Na}$ busca de entender a intenção pedagógica para o uso da informática, a pergunta como você faz uso da tecnologia e o porquê trouxe-nos um panorama de como este uso é realizado nas atividades da educação Infantil:

Docente A: gosto de levar meus alunos a sala de informática, às vezes faço assim, conto uma história e procuro na coordenação atividades sobre o que 
contei, procuro articular o trabalho seja para fazerem um desenho no computador e depois imprimir.

Docente B: Uso pouco o espaço de informática, tem coisas mais interessantes, exploro o contar histórias, o uso do material concreto, às vezes passo um mês sem ir lá, acho complexo organizar atividades que envolvam as duas coisas.

Docente C: gosto dos joguinhos que o computador traz, costumo levar os alunos a sala de informática e deixar que eles explorem os jogos que o computador tem, às vezes sigo o planejamento com alguma historia para contextualizar, mas acho que preciso de um descanso e o computador proporciona esse momento na minha aula.

Docente D: gosto de explorar com os alunos as possibilidades, sempre preparo algo e fiz como minha colega de sala um roteiro que a cada 15 dias uma prepara um material, usamos o data show para historinhas, o blog para pesquisar e postar as atividades, valorizo atividades onde eles manipulem os recursos concretos e o ambiente virtual.

Docente E: Uso bastante o espaço da informática, gosto de aliar o computador ao que aprendemos na sala... tenho dificuldades e às vezes preciso de ajuda, mas exploro os joguinhos e os vídeos do Youtube como forma de ter uma ajuda diferente na aula.

Docente F: difícil admitir viu, mas não uso a sala de informática... não domino os recursos e acho que as crianças são muito bombardeadas pela informática em casa e a escola tem que proporcionar o contato com outras tecnologias, brinquedos e convivência em sociedade. Já tive atividades preparadas pela coordenação, tentei, mas não consigo, acho difícil e desanimador... as crianças me superam..rsrs..

Percebe-se que a docente procura, conforme seu domínio e conhecimento de uso, inserir a linguagem digital em suas práticas, umas mais que outras, ao extrapolarem o ambiente escolar com pesquisas em blogs e sites; e outras ainda enfrentam barreiras decorrentes de seu conhecimento limitado. O interessante a observar é que as docentes ressaltam o planejamento que alia a informática a um projeto pedagógico como eficaz e fator que incentiva o uso. Outro fator determinante é a parceria, a motivação pelo contato com o outro que está inserido no ambiente e auxilia o colega a integrar os recursos de forma contextualizada.

O currículo em movimento da educação infantil destaca que a criança já é bem curiosa e inserir recursos tecnológicos e midiáticos é uma oportunidade de propiciar a incorporação de elementos básicos das tecnologias à rotina de criação e ressignificação de imagens e produção de narrativas.

Tem-se a possibilidade de explorar ações e intencionalmente aliar o material concreto ao material midiático com o uso de vídeos para contextualizar ou fomentar a curiosidade infantil. Ao serem indagadas sobre o uso que fazem dos recursos na sala de aula, a docente D citou: 
$\mathrm{Na}$ sala de aula, costumeiramente, tenho aliado os diversos recursos tecnológicos disponíveis na escola. Gosto de contar historias com o livro e com o uso do data show... ver aqueles olhos brilhando é bom demais... No projeto sobre os animais visitamos o zoológico, então, continuando a visita que fizemos, peguei as fotos que tiramos dos animais, contei uma historia resumida da visita e partimos para pesquisar onde vivem os animais que eles mais gostaram, daí foi viagem viu... a girafa, o leão o macaco e outros mais... passei umas duas semanas falando sobre o tema, eu aprendi muito e percebi que eles estavam encantados. Tentei mostrar que o computador tem coisas legais além de jogos e desenhos. Para melhorar a interação sempre sugeri que contassem o que estavam gostando, o que estavam aprendendo, usei a ferramenta de desenho e sério ficou lindo...

O fenômeno da aprendizagem constrói-se num movimento dialógico e dialético, todos os envolvidos são considerados sujeitos do processo de ensino e de aprendizagem, participam construindo e reconstruindo saberes e significando experiências. $\mathrm{O}$ trabalho aliado de projetos com a tecnologia pode transpor os limites da sala de aula, na perspectiva de inserir as crianças em experiências e vivências que, segundo o currículo em movimento, são essenciais para ressignificar a percepção infantil, onde o aprender significa conectar-se e transformar-se tendo como referência última o mundo onde a ação em reflexão manifesta-se, concatena-se (FREIRE, 2003)O professor adquire a concepção de parceiro da aprendizagem, ambos são parceiros e sujeitos do processo de conhecimento, cada um atuando segundo o seu papel e nível de desenvolvimento, tem-se o entendimento que o educador faz com os seus alunos e não faz para os alunos (FREIRE; SHOR, 1986). 


\section{ELUCIDANDO AS REPRESENTAÇÕES DAS PROFESSORAS SOBRE O USO DA INFORMÁTICA COM CRIANÇAS PEQUENAS}

No questionário, as docentes tiveram que assinalar, com base em suas concepções sobre o uso pedagógico da informática envolvendo crianças pequenas, qual o pressuposto que justificava a inserção de recursos tecnológicos na escola. As professoras assinalaram unicamente a "hipótese de ordem pedagógica". Elas encaram a informática como fomentadora de uma nova possibilidade de aprendizado, pensamento e crescimento emocional e cognitivo.

Quando indagadas sobre o porquê, as docentes justificaram da seguinte forma:

Docente A: ... vejo que a informática ... pode sim auxiliar no aprendizado e até motivar, a cada quinze dias vamos ao laboratório durante uma hora e eles gostam das atividades, aprendem e interagem... Lá posso levá-los ao zoológico sem sair da escola, podem ver animais, formas e corres em diversos tons sem precisar sair é ótimo è um momento impar de aprendizagem.

Docente B: Não posso negar o encanto das crianças e a facilidade, eu aprendo junto com eles. Não domino muito os recursos, mas acho que a tecnologia tem suas vantagens, mas um professor que prepara bem suas aulas não precisa estar preso à tecnologia. Esse negócio de computador chegou na escola após todo mundo pensar que ele ia dominar o mundo e nem por isso me sinto ultrapassado... não nego que se souber usar seja também uma oportunidade de fomentar o aprendizado.

Docente C: Sem dúvida há uma nova possibilidade de aprendizagem e ensino, principalmente as crianças que vivem cercadas de incentivos tecnológicos. Acredito que há possibilidades pedagógicas, mas preciso encontrá-las para além dos passatempos que meus alunos vivenciam no laboratório, até eu já to enjoada dos joguinhos.

Docente D: A informática mudou a escola, deixei o mimeógrafo e agora sinto que estou com a possibilidade de ensinar as coisas de uma forma mais dinâmica. A interação e ter condições de extrapolar os limites da sala me atraem muito.

Docente E: Concordo que o incentivo pedagógico para a inserção foi grande, e continua ativo, mas mesclo aí também a questão do computador hoje está em tudo e como as crianças precisam ser ensinadas acho que quanto mais cedo aprenderem a tecnologia, mas rápido estarão dominando os recursos e inseridas na sociedade.

Docente F: A informática pode trazer novas possibilidades de aprendizado... Mas...sei não viu... é muita exposição... Uso pouco, talvez devido a minha limitação, mas as crianças podem aprender sim, podem ser motivadas e é fascinante para quem saber usar. Mas a melhor tecnologia é o professor, o computador como meio é legal, mas precisa de algo mais que só o professor tem.

Vê-se, nas falas das docentes, um deslumbramento e uma euforia em relação à inserção da informática. Analisando, percebe-se que há um direcionamento para o 
entendimento que a hipótese de ordem pedagógica estrutura a adoção da tecnologia e atua diretamente na formação da representação que as docentes fazem.

Infere-se que a incorporação desses recursos à educação é motivada não apenas como um meio para ensinar conteúdos significativos, mas principalmente pelos processos cognitivos, sociais e afetivos que suscitam. Percebe-se que a inserção de recursos informatizados tem sua estrutura na perspectiva que estes são fundamentais para criar condições que possam "contribuir para uma mudança da postura pedagógica do professor e para um repensar deste sobre a sua própria prática" (MENEZES, 1993, p. 17).

Segundo Valente (1993, p. 01) "para a implantação dos recursos tecnológicos de forma eficaz na educação são necessários quatro ingredientes básicos: o computador, o software educativo, o professor capacitado para usar o computador como meio educacional e o aluno", sendo que nenhum se sobressai ao outro. O autor acentua que, "o computador não é mais o instrumento que ensina o aprendiz, mas a ferramenta com a qual o aluno desenvolve algo e, portanto, o aprendizado ocorre pelo fato de estar executando uma tarefa por intermédio do computador" (p.13). Não é um dos envolvidos que tenha de sobressair sobre o outro, mas vê-se que há uma articulação para a construção de experiências significativas, o que para as crianças pequenas não é diferente.

A inserção da informática só tem validade e efetividade se levar a mudanças na forma de ensinar (MORAN, 1998), isto é, se ela transformar a sala em um ambiente de pesquisa e comunicação. A informática pode funcionar como motivação para a curiosidade e novas experiências, desde que inserida como forma de pesquisar e extrapolar os limites. Para Kenski (2002) a motivação dos estudantes pode aumentar quando a professora constrói um clima de confiança, abertura e cordialidade, o que, em última instância, depende do modo como a informática é incorporada e percebida.

Entendendo que as fragilidades na formação atuam como formadores de representações sociais que podem levar ao uso ou a rejeição, as docentes foram incentivadas a assinalar qual a concepção que caracteriza o uso da tecnologia na escola. Pelas respostas, percebe-se que há uma divisão na interpretação. As docentes A, B e E traduzem o computador como "meio para simulações e jogos": momento em que a criança faz uma atividade de simulação no computador e os jogos servem mais como entretenimento, ambos estimulam o desenvolvimento do raciocínio sofisticado e a habilidade de soluções do problema.

A Docente A acrescentou: "as simulações são o melhor do computador, a possibilidade de cativar as crianças com imagens e narrativas computadorizadas faz a aula 
mais dinâmica e interessante. Possibilita também, a fixação de aprendizagens com vistas a explorar novos conceitos e experiências que incitam a criança pequena a pensar".

As docentes B e D acentuaram o computador como meio de aprendizagem por descobertas, a criança extrapola as vivências comuns da escola, pode conhecer ambientes diversos e interagir e colaborar com descobertas. Para atingir tal finalidade, é necessário que haja uma intenção pedagógica para que a aprendizagem seja sistematizada.

Conforme o Currículo em Movimento para a educação infantil da SEDF (2013), as aprendizagens são propiciadas por uma multiplicidade de linguagens:

As palavras, gestos, afetividade, desenho, olhares, enfim tudo que compõe o espaço educativo funciona como referência de constância e continuidade para a criança, tornando a instituição educativa confortável e abrindo caminhos para a descoberta e as manifestações infantis (ALEXANDROFF, 2010).

A integração da informática é vista como possibilidade de contribuir para instigar a criança a conhecer o mundo, valorizando o conhecimento de cada uma ao organizar suas ideias para conviver em sociedade, ou apresentando-lhes um mundo novo rico em experiências encantadoras.

Entendendo que a informática pode agir como fomentadora de aprendizagens, a questão agora é o que em sua opinião, falta para que os recursos tecnológicos sejam mais bem aproveitados na escola?

Tem-se, aqui, um panorama das interpretações que atuam para a adoção da informática no trabalho com crianças pequenas. As docentes enumeraram alguns fatores:

Formação prática - aliar aos momentos de formação ideias pedagógicas factíveis de serem executadas dentro da realidade do trabalho da educação infantil; (docente A e D)

Utilidade na pedagogia (no trabalho com crianças) - inserir tecnologia é moda, mas até o momento não vi mudança no ensino e aprendizagem que seja significativa (docente $\mathrm{B}$ e F)

Computadores com internet mais veloz - a falta de manutenção atrapalha, são crianças que mexem e as máquinas quebram e não tem um técnico para conserto rápido, às vezes, você programa a aula e tudo dá errado, nada funciona. (docente $\mathrm{C}$ e $\mathrm{E}$ )

No primeiro fator, vê-se a formação continuada como algo central para que a informática adquira o significado para a docente. Equipar e capacitar precisam caminhar 
juntos. Laboratórios de informática sem professoras capacitadas para operá-los não surtem o efeito esperado de inserção e mudança de paradigmas; ao contrário, tem levado a criação de concepções errôneas sobre a tecnologia ser superior a professora por esta desconhecer o modo de como usá-la.

Considerando o modelo para aceitação e uso de tecnologias UTAUT, compreende-se que a intenção de uma professora em adotar determinada tecnologia está diretamente ligada a utilidade percebida ou a sua adequação ao trabalho. Em outras palavras, a ligação prática da pedagogia com a informática, por meio de atividades que demonstrem a professora a praticidade e a facilidade de execução da tarefa pedagógica com as crianças, e proporcione um fomentar de curiosidade de ambos, é determinante na associação da informática com o trabalho pedagógico.

As docentes com maior domínio dos recursos informatizados não relataram problemas com o uso dos computadores, entretanto, as que não dominam as máquinas relataram somente os problemas técnicos. Em sua entrevista, percebe-se uma adesão a comportamentos que interpretam uma resistência quanto à inserção de tecnologia com as crianças pequenas, ao classificar o uso como "moda", "excesso de exposição", "descanso".

Após analisar o perfil tecnológico e de formação para uso de recursos informatizados, pensou-se em um trabalho com imagens e palavras que expressassem o sentimento de cada uma das docentes ao se depararem com a possibilidade de uso do computador com as crianças pequenas na sala de aula. Estas imagens e palavras foram o material gerador para a roda de conversa, com a finalidade de propor uma interpretação da representação que cada professora concebia frente ao desafio que lhe é posto referente a informática : aceitar e usar (concepção positiva) ou rejeitar e não usar (concepção negativa).

A seleção contou com o total de vinte imagens diversas, retiradas de blogs e sites da internet que trabalham com a temática de professores, informática e educação. As palavras foram designadas pelas professoras que ao escolherem a imagem que estava disposta na mesa da sala, onde foi realizada a roda de conversa, separava em positiva ou negativa e associava a palavra ou frase que justificava sua concepção.

Durante a atividade, elas apresentaram a imagem, explicaram como a interpretavam e justificaram a escolha da palavra. Para as imagens e palavras de associação positivas as docentes elencaram: 
Figura 2 - Aprendizagem

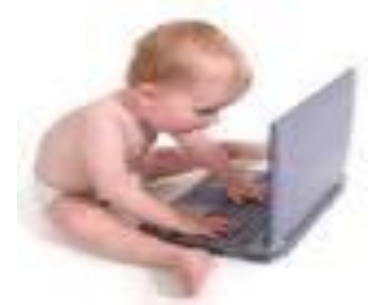

Fonte: www.mundodastribos.com.br

Docente A: Aprendizagem - Vejo que a criança pode experimentar e aprender muito com a informática, usar a linguagem digital enriquecendo a aula com recursos tecnológicos instiga a curiosidade que leva a motivação para a aprendizagem.

A análise da figura mostra a curiosidade da criança frente às experiências a que são confrontadas com o uso do recurso tecnológico. Outra inferência percebida é que o recurso fomenta uma postura de aprendizagem por imagens e sons que enriquece as possibilidades e a motiva a adquirir sentido no que está sendo apresentado, com uma linguagem que cativa a criança.

O recurso no contexto educativo atua como uma ferramenta por meio da qual a criança idealiza e desenvolve um conhecimento, seja reproduzindo um saber ou construindo uma aprendizagem. Desse modo, o aprendizado é estimulado pelo fato de a criança executar uma tarefa por meio do computador, na qual explora possibilidades de ressignificar as experiências e é impelida a aprender de forma lúdica, seja por jogos e simulações, seja por outras formas de motivação.

O recurso tecnológico, na sala de aula, possibilita que o aluno busque uma série de oportunidades. A professora tem a responsabilidade de fazer a mediação para que essas informações sejam uma construção de saberes de forma responsável e autônoma, pois a criança, aos poucos, vai se familiarizando com a "máquina" e começa a navegar por caminhos novos, na busca de outros conhecimentos que certamente ultrapassam as fronteiras daqueles delimitados pela capacidade humana da professora.

Figura 3 - Mudança

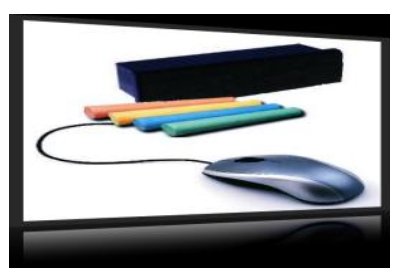

Fonte: http://porvir.org 
Docente B - Mudança - a dinâmica da sala muda, as crianças ficam concentradas e interagem com as imagens e sons apresentados, expande a sala por fronteiras que são capazes de incitar a novas descobertas.

As relações educativas são diretamente afetadas pela presença da tecnologia. Para Levy (2001), toda tecnologia inserida no contexto escolar traz em sua essência a necessidade do envolvimento de todos os agentes da escola, sendo os professores em primeiro plano, depois os estudantes e, por último, os agentes administrativos, a equipe pedagógica e a comunidade. Todos esses agentes necessitam se capacitarem para que haja uma perfeita interação no processo de ensino, em que a aprendizagem venha a ocorrer de forma estimuladora e sob uma nova perspectiva.

Para Kenski (1998), a tecnologia só tende a crescer em sua amplitude de inserção, pois é inevitável, nos dias atuais, e as velozes transformações tecnológicas da atualidade impõem novos ritmos e dimensões à tarefa de ensinar e aprender. É preciso que se esteja em permanente estado de aprendizagem e de adaptação ao novo.

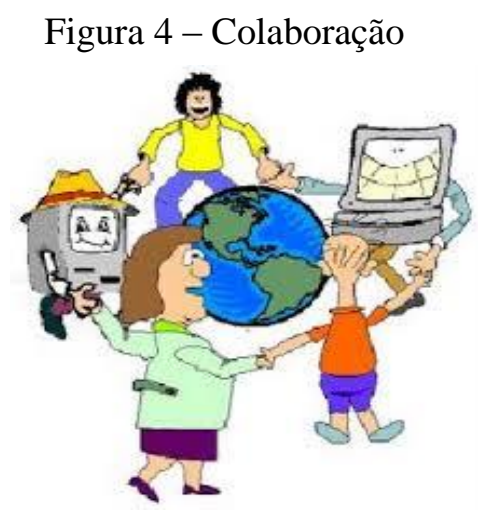

Fonte: Blog Educação e Tecnologias

Docente C - Colaboração - a significação do conhecimento é desmistificada com a colaboração entre o computador e as crianças mediada pela professora, e entre as crianças e seus pares.

Para Levy (2001, p.132), “é na escola que o indivíduo tem a oportunidade do aprendizado interativo e cooperativo, sendo o principal canal de acesso para a inclusão e cidadania”. O autor afirma ainda que o computador proporciona, na atualidade, que os professores aprendam ao mesmo tempo em que os estudantes, oportunizando a atualização contínua tanto dos saberes quanto das competências didático-pedagógicas do educador.

Para Tarja (2001), o professor deve estar aberto para mudanças, principalmente em relação à sua nova postura: o de facilitador e coordenador do processo de ensino aprendizagem; ele precisa aprender a aprender, a lidar com as rápidas mudanças, ser dinâmico 
e flexível. Acabou a esfera educacional de detenção do conhecimento, do professor "sabe tudo" (TARJA, 2001, p.114).

Figura 5 - Inovação Pedagógica

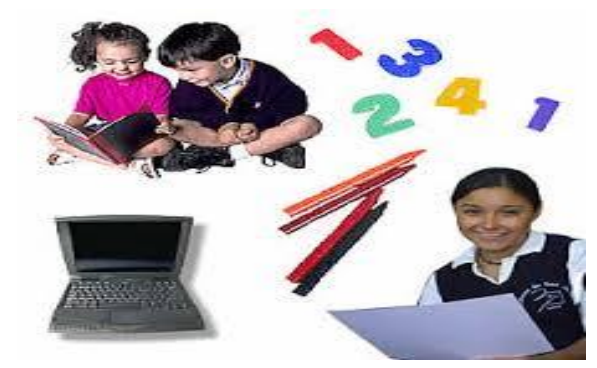

Fonte: http://porvir.org

Docente D: Inovação Pedagógica - possibilidade de criação de experiências mistas e inovadoras de aprendizagem, desde que articuladas diversas culturas para o favorecimento do desenvolvimento integral das crianças.

A inovação pedagógica envolve mudanças com posicionamento crítico, explicito ou implícito, face às práticas pedagógicas tradicionais. Assim, a escola é levada a refletir sobre o aprendizado construído no âmbito das atividades desenvolvidas por ela, o aluno é o protagonista da aprendizagem e o professor o ator coadjuvante, pois, por meio do construcionismo que propõe que a criança elabore suas próprias estratégias para pescar o conhecimento, ela tem a possibilidade de desenvolver suas percepções e habilidades.

Martins et al (1999) apontam que o computador apresenta várias caraterísticas que o encaixam na visão de inovação; entre elas está a de possibilitar as diversas formas de relação, enriquecendo as experiências dos indivíduos. Portanto, ele colabora no desenvolvimento das pessoas e possibilita, também, a construção do conhecimento pelo próprio sujeito, por meio de sua exploração autônoma e independente.

Segundo Lollini (1991, p. 43):

[...] um dos méritos do computador no campo da educação é, porém, o de tentar resolver um dos grandes problemas da educação: como respeitar o ritmo da aprendizagem, como evitar defasagens entre os tempos propostos (ou impostos) pela escola e o tempo necessário ao aluno numa atividade particular em um determinado momento da vida.

Figura 6 - Criatividade

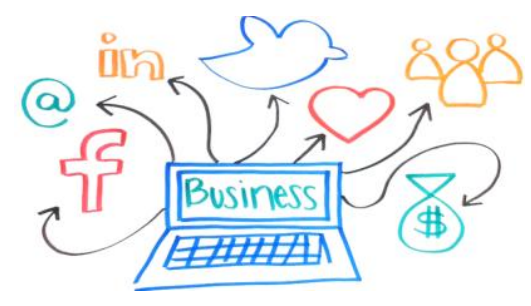


Fonte: http://www.culturamix.com/tecnologia/novas-tecnologias

Docente $\mathbf{E}$ - Criatividade - favorece a criação e exploração de dinâmicas de sentido diferente, criar além do papel, mas significando isso dentro do trabalho pedagógico.

O computador na escola é apresentado por Papert (2008) como uma ferramenta extraordinária, que possibilita ao aluno descobertas e a construção como a materialização do pensamento, não como mera manipulação de objetos. Conforme Lollini (1991, p. ):

\begin{abstract}
Ante o computador, aluno e professor são pesquisadores. O professor procura quais sejam as interações mais produtivas dentre as possibilidades que a máquina apresenta ao usuário. O aluno, por sua vez, procura a solução dos seus problemas e, assim fazendo, constrói ao mesmo tempo concreta, física e mentalmente o próprio pensamento.
\end{abstract}

Figura 7 - Interação

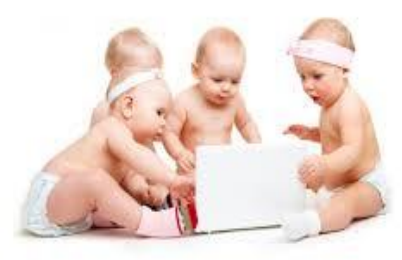

Fonte: http://mariaeduardasandy.blogspot.com.br/

Docente F - Interação - o diálogo construtivo com os pares é o aprender em contato com o adulto professor, ou com os colegas de sala, ainda podendo interagir com outros estudantes de qualquer lugar.

O aprendiz constrói alguma coisa, ou seja, é o aprendizado por meio do fazer. Em segundo lugar, o fato de o aprendiz estar construindo algo do seu interesse e para o qual ele está bastante motivado, com envolvimento afetivo, torna a aprendizagem mais significativa (VALENTE, 2001).

O conhecimento não está nem no sujeito nem no objeto, mas na interação entre ambos. Agindo sobre os objetos do mundo e sofrendo a ação destes, o homem vai ampliando a sua capacidade de conhecer e, consequentemente, o próprio conhecimento. O computador não substitui o adulto/educador ou o grupo, mas multiplica as situações em que o alcance de níveis mais elevados de desenvolvimento real é ativado, pela experimentação de situações simuladas de passatempos e aprendizagens.

Face aos avanços das inovações pedagógicas, as tecnologias propiciam a criatividade, a construção de aprendizagens lúdicas, com respeito aos diferentes ritmos, às diferentes 
necessidades, aos diferentes interesses. Desse modo, o currículo também sofre mudanças, ele deve ser construído a muitas mãos e sendo assim, as tecnologias permitem às pessoas maior inclusão.

Reafirmando Papert (2008), Fino (2003) ressalta que os computadores (os recursos tecnológicos), como ferramentas de aprendizagem, podem criar novos contextos, facilitar a transdisciplinaridade, anular a massificação dos alunos e identificar outros lócus de conhecimento além da escola. Isso porque eles lhes dão acesso ao conhecimento e às ocorrências do dia a dia, o "eu" se projeta pela "janela" e ganha espaço onde o horizonte não é algo inalcançável como antes. Os instrumentos tecnológicos permeiam a vida das pessoas e dentro de uma heterogeneidade transforma a diversidade em homogeneidade. Pessoas, dos seus smarts, acessam variados tipos de conteúdos e executam infinitas tarefas. Os gostos são os mais variados possíveis, tanto em relação ao uso da tecnologia acessível a todos, quanto aos programas desenvolvidos amplamente para diversos gostos, tipos e ambientes, sendo eles formais ou informais. Assim:

As práticas pedagógicas ocorrem onde se reúnem pessoas, das quais algumas têm o propósito de aprender alguma coisa e, outras, o propósito de facilitar ou mediar nessa aprendizagem. Ou quando todas têm o mesmíssimo propósito de aprender alguma coisa em conjunto. (FINO, 2008, p. 03)

Devidamente utilizada, a linguagem digital impõe um repensar à prática educativa e instiga a redefinição dos papéis dos envolvidos no processo educativo. A análise das imagens e sua relação com as palavras escritas e selecionadas pelos docentes nos levam a inferir que a informática traz conceitos positivos como a inovação, que é entendida como mudança e melhoria de processos educativos relativos ao ensino e a aprendizagem, por meio do favorecimento da interação, criatividade e colaboração.

Considerando as representações negativas, os docentes associaram as seguintes imagens e palavras:

Figura 8 - Excesso de atividades

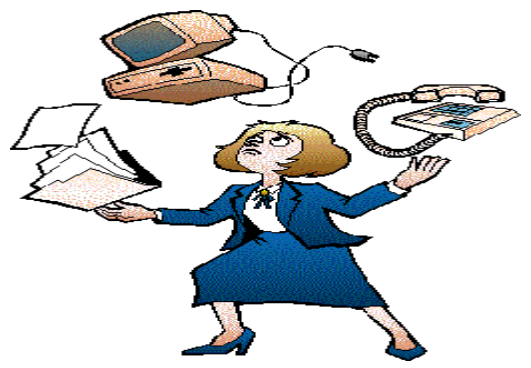

Fonte: Blog : As tic's e a Escola-Fabiane Gouveia 
Docente A - A tecnologia é mais umas tarefas para ser realizada e como às vezes não sabem operar as máquinas nos enrolamos e ficamos atarefados com muitas atividades, que sobrecarregam e prejudicam o trabalho pedagógico, as vezes ficamos dependentes e só executamos determinada ação com a informática presente.

Esta representação, por muito tempo, fez parte do imaginário não somente das professoras, mas da sociedade em geral. Foi comum especialistas divulgarem pesquisas que caracterizavam a tecnologia como algo nocivo à saúde e à sociedade em geral. A exemplo disso, o psiquiatra Richard Graham criou, em Londres, um hospital para o tratamento de viciados em tecnologia. Segundo ele, "o excesso de tecnologia esgota o cérebro da mesma forma como acontece com a depressão e como acontece com o uso de anfetaminas, por exemplo, que dão muita empolgação para depois deprimir" (GRAHAM, DATA, p. ).

Figura 9 - Receio de ser substituído pela tecnologia

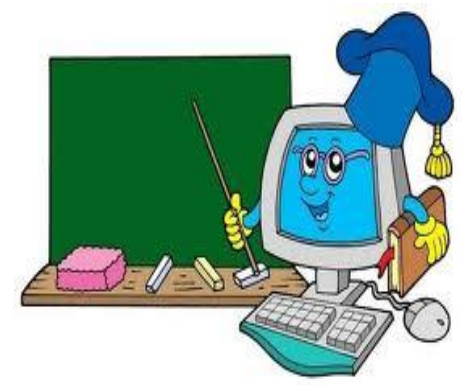

Fonte: http://pedagogiaetecnologiaemfoco.blogspot.com.br/

Docente B - Pensei e hesitei em ceder à tecnologia, acreditava que as crianças pudessem achar o computador mais atraente e motivador. Cheguei a resistir pensando que o laboratório fosse tomar o lugar das outras atividades.

"Existe um professor que pode ser substituído por uma máquina, é porque ele realmente merece ser substituído". Esta afirmação foi uma provocação do indiano Sugata Mitra, professor de Tecnologia Educacional da Newcastle University, na Inglaterra, e professor visitante do Massachusetts Institute of Technology, o famoso MIT. Para o pesquisador, as crianças podem, sim, aprender sozinhas, mas a capacidade de aprender necessita ser motivada, apoiada e instigada. Então, tem-se a necessidade de intermediação de um adulto no processo de aprendizagem. Mitra explica que o papel do professor, assim como o currículo, deve ser reformulado para que as crianças se interessem pelo estudo.

Os professores devem ter consciência de que a tecnologia é capaz de ajudar o professor, mas não o substitui. "Pode ajudá-lo a ensinar melhor e com melhor qualidade. Mas não reduzirá o esforço necessário na sala de aula. Pelo contrário, creio que devemos aumentar 
o número de professores" (HAWKINS, 1995, p. 61) para um melhor uso e adaptação da tecnologia à realidade pedagógica.

Figura 10 - Dificuldade em entender a tecnologia

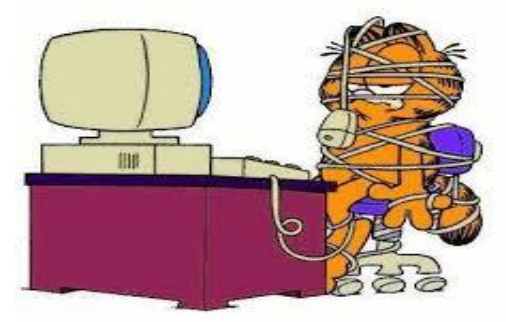

Fonte: http://teodomirotoledopiza.blogspot.com.br/

Docente C - Não é fácil compreender e saber todos aqueles comandos para executar as tarefas, dá um nó na cabeça. Outra coisa, o medo de fazer algo e desconfigurar a máquina é grande, viu. Eu mesmo tenho o maior cuidado.

Moran (2006) afirma que, em geral, os professores têm dificuldades no domínio das tecnologias e tentam fazer o máximo que podem. Diante deste hábito, eles mantêm uma estrutura repressiva, controladora, repetidora. Muitos tentam mudar, mas não sabem bem como fazê-lo e não se sentem preparados para experimentar com segurança. Ainda segundo o Moran (2006, p. 32), "é importante diversificar as formas de dar aula, de realizar atividades e de avaliar".

É preciso mais do que um simples domínio instrumental, torna-se necessário um conhecimento das potencialidades proporcionadas por cada tipo de tecnologia, de acordo com cada método de ensino a ser aplicado. O professor precisa ser reflexivo e se questionar sobre como pode utilizar determinada tecnologia (ROSA, 2013).

Figura 11 - Falta de tempo na preparação das atividades / em conhecer as potencialidades e fazer cursos

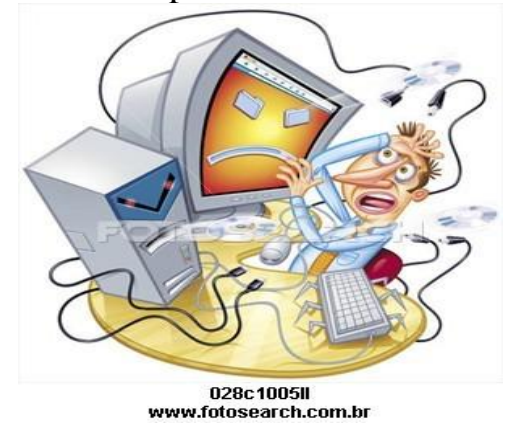


Docente D: Eu mesmo sofro disso, não tenho tempo de fazer cursos para aprender a operar as tecnologias, ainda mais que aqui os cursos são ministrados no Plano Piloto, ando de ônibus e é um pouco difícil. Mas entendo que é importante inserir a tecnologia nas aulas e principalmente com as crianças.

Pesquisas apontam que a sobrecarga de atividades docentes acentua o aparecimento de doenças causadas pelo excesso de atividades (ASSUNÇÃO e OLIVEIRA, 2009; OLIVEIRA, 2010). Os docentes compreendem a importância de usar a tecnologia, mas devido a dificuldades no manuseio, alguns sentem se desmotivados e acabam por resistir a sua incorporação nas escolas. O trabalho com oficinas na própria escola é uma das estratégias para os professores aceitarem e manusearem a tecnologia.

Figura 12 : Insegurança

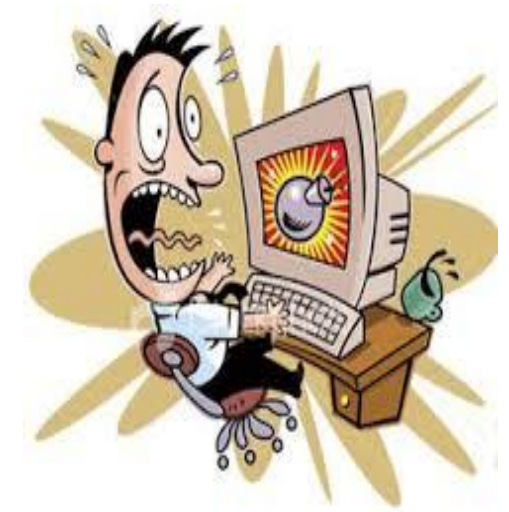

Fonte: http://www.jbtnoticias.com

Docente E - não consigo operar o computador , uma criança pode acessar algo que não seja permitido e eu não saber voltar, e ver a forma como dominam o mouse e a tela me deixa triste, pois não sei usar a tecnologia.

O professor é visto como condutor do processo ensino e aprendizagem, aquele que domina o conteúdo, contribuindo para o aprendizado do aluno. Dentro do contexto educacional, em especial na sala de aula, o professor se torna ator principal e todos os olhares estão direcionados para sua figura. Naquele momento, o professor sente a relevância de seu papel de transmitir conteúdos sistemáticos, críticos, concretos e articulados às realidades sociais. O professor tem a ciência que seu papel de educador precisa ultrapassar a mera transmissão do conhecimento, que é preciso despertar nos alunos a participação e a criticidade (VEIGA, 1991). Segundo Miranda (2007), de fato, o uso das tecnologias exige um esforço de reflexão e de modificação de concepções e práticas de ensino que a maioria dos professores não esta disponível para fazer. E não será tarefa fácil, pois é preciso esforço, persistência e empenho (ROSA, 2013). 
Figura 13 - Vergonha de não estar incluído no mundo digital

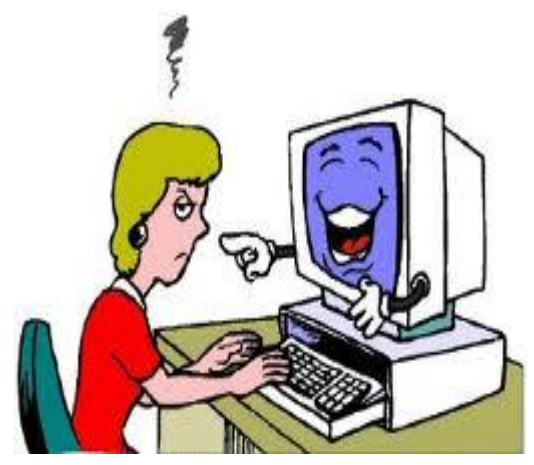

Fonte: http://pedagogiaetecnologiaemfoco.blogspot.com.br/

Docente F: As crianças sabem mais do que eu, falou que é tecnologia, não é o meu forte, me sinto perdida com tantos botões.

Sentir-se incluído no mundo digital não é apenas saber utilizar pacotes de programas, a questão da inclusão está ligada a ser leitor-autor. Pela quantidade de informações veiculadas pelas redes sociais, internet e mídia, mais importante que acessá-las é saber filtrar e repensar o que esta sendo divulgado criticamente.

Para Pierre Lévy (1999, p. 238):

[...] não basta estar na frente de uma tela, munido de todas as interfaces amigáveis que se possa pensar, para superar uma situação de inferioridade. É preciso, antes de mais nada, estar em condições de participar ativamente dos processos de inteligência coletiva que representam o principal interesse do ciberespaço.

Percebe-se que as professoras têm consciência da importância da informática em suas atividades. Elas compreendem que, por se tratar de uma inovação, seu uso requer uma atenção especial, tendo em vista o pouco domínio sobre as tecnologias. Apesar de algumas se sentirem ameaçadas, grande parte as encaram com um instrumento para enriquecer a sua prática pedagógica.

Entretanto, o diferencial está em preparar a professora para o uso dessa tecnologia, por meio de oficinas e diálogos sobre o uso, mantendo uma atualização constante sobre a linguagem digital e suas aplicabilidades. As professoras precisam ser motivadas pelo desejo de crescer, de aprender e também de ensinar. Carecem tomar consciência da necessidade de criar e inovar constantemente.

Para Flores (1996, p. 87) necessitamos seguir algumas lições: 
a) Não basta jogar computadores para os alunos ou para os professores. Deve haver um esforço na formação dos professores em utilizar qualitativamente este instrumento.

b) A tecnologia não aumenta espontaneamente o desempenho dos alunos. Aumenta sim, a necessidade de o professor mediar o processo do aprendiz.

c) Alta tecnologia não significa qualidade, falha-se ao acreditar cegamente em interatividade e multimídia. Ter a rede de pesca não significa ter o peixe.

d) Nenhum equipamento ou programa substitui um bom projeto educacional.

Portanto, não precisamos esperar que a tecnologia no forneça uma solução mágica e rápida para a educação, mas, certamente, ela poderá ser usada pela professora como um importante instrumento pedagógico, oportunizando que a criança amplie o seu conhecimento e a sua criatividade. Isso porque, afinal, criatividade não se ensina, se constrói (MATTEI, 2011). 


\section{CONSIDERAÇÕES FINAIS}

O avanço da ciência e da tecnologia operaram transformações que constituem desafios que geram conflitos, intranquilidade e afrontam o comodismo da escola. Entretanto, conhecer as razões que influenciam a adoção de recursos informatizados, em uma escola pública de Educação Infantil, traz a possibilidade de elucidação teórica e prática no que diz respeito à compreensão das representações dos professores - aspecto primordial para a condução de um trabalho em prol da melhoria da escola.

A inserção de qualquer inovação no âmbito escolar é fonte de movimentação em todos os setores da escola. A investigação aponta que os docentes ficam inquietos e amedrontados com a possibilidade de que esta inovação ou mudança altere sua posição como detentor do conhecimento, afete seus salários e mude a rotina educacional, agregando mais atividades ao seu dia a dia. Entretanto, considerando os professores, percebe-se que eles, como agentes executores de grande parte das políticas educativas para o setor, muitas vezes, não conhecem ou não são capacitados para uma aplicação eficaz. Tal desconhecimento pode ser estudado como um dos fatores que contribui para a formação de representações sobre o objeto, construídas não por bases empíricas, mas por suposições, às vezes absurdas, sobre o real papel da inovação em questão.

Castanho (2000) explica que inovação é uma palavra que sobressai na literatura educacional, aparecendo atrelada à perspectiva de soluções para o "marasmo" dos sistemas de ensino. Inovação não significa descoberta nem invenção, mas ação para alterar as coisas pela introdução de algo novo e pode se dar a partir de três dimensões: (a) pela investigação; (b) por meio da solução de problemas; (c) com base na interação social, sendo a primeira o caminho mais adequado.

Para Japiassu (1983), os docentes resistem à inovação porque são submetidos a um processo de formação baseado no chamado conhecimento educacional científico, o qual se ancora na pesquisa positivista e é responsável por generalizações que interessam aos planejadores de currículos e supervisores, o que acaba por desarticular tentativas de criação pedagógica. Amarrados à racionalidade cientifica (SANTOS, 2003) os professores encontram mais dificuldades para incorporar o computador e rede ao seu fazer pedagógico.

Partindo do entendimento que apenas equipar as escolas com laboratórios de informática com computadores novos, acesso à internet e demais recursos tecnológicos não representam, sozinhos, a inserção de uma nova proposta pedagógica no processo educativo, a 
formação continuada está como uma fonte de quebra de barreiras, pois o conhecimento de aplicações pedagógicas dos recursos é mais importante que sua simples presença.

Os professores da escola estudada interpretam que os recursos informatizados são ferramentas eficazes no aperfeiçoamento do processo educacional. A sua utilização cria novas formas de ensinar e aprender, trazendo à educação características inovadoras capazes de motivar professores e alunos. Ela é bastante significativa para o desenvolvimento da autonomia, da criatividade e da possibilidade de execução na construção do conhecimento. Os aparatos tecnológicos são atraentes aos alunos e sua utilização, dentro do contexto de experiências significativas, aliadas à realidade das crianças pequenas, é tida como causadora de impacto e como motivadora de interesse.

Considerando a inserção de inovações tecnológicas como ponto nevrálgico no cotidiano do professor, é interessante perceber que as representações negativas contribuem de forma a aumentar as tensões que levam a comportamentos de resistência ao uso e aceitação.

Entre os potenciais de resistência para a aceitação de recursos informatizados, a pesquisa nos leva a apontar as concepções e atitudes mais recorrentes nas falas dos professores pesquisados:

Desconhecimento de possibilidades pedagógicas para o trabalho com as crianças pequenas. Os docentes demonstraram temer o que não conhecem e formulam ideias de que seja complicado aderir ao uso tendo em vista a natureza complexa da informática, a necessidade de conhecer códigos e lembrá-los para executar as tarefas didáticas.

> Outro potencial de tensão identificado é ausência efetiva de uma formação para o uso pedagógico das tecnologias. Apesar de esta ser a proposta almejada pelo ProInfo integrado do Ministério da Educação, ela não está sendo alcançada. Entre as recorrentes queixas apuradas, tem-se a descontextualização do software oferecido no curso, Linux educacional, frente a plataforma tecnológica disponível nos computadores existentes nas escolas que e o sistema operacional do Windows. Está é uma fala do grupo que remete a descaracterização da formação oferecida por ser considerada inadequada à necessidade de conhecimento para a operação do recurso informatizado disponível na escola.

$>$ Referente ao programa operacional, os docentes alegam que não dominam o pacote tecnológico do programa e em suas casas tem familiaridade com o Windows, mas quando vão utilizar o Linux, o desconhecimento e o pouco uso, os leva ao esquecimento das funcionalidades. Este ponto nos remete ao modelo UTAUT de aceitação de tecnologia e o construto que determina os comportamentos de uso ligados 
à experiência de uso e articulado à facilidade e utilidade percebida, condição primordial para a aceitação.

> Medo de ser substituído pela tecnologia - esta concepção afasta os professores da informática, pois temem o que não conhecem e não dominam. Formados com base em uma pedagogia de métodos e técnicas tradicionais, sentem-se amedrontados com a possibilidade de que algo saia do planejamento e não possam reformular a tempo de continuar com o domínio de sua classe.

Entretanto, esta concepção está pautada no desconhecimento do verdadeiro potencial das tecnologias, e que estas nunca substituirão o professor, desde que ele re-signifique seu papel e sua identidade a partir da utilização das novas abordagens pedagógicas que as estas facilitam. A adoção das TIC, em sala de aula, traz para os educandos muitos caminhos a percorrer e esse caminho necessita da presença do professor. Isso porque é ele quem vai dinamizar todo este novo processo de ensino-aprendizagem por intermédio dessa ferramenta, explorando-a ao máximo com criatividade, de modo a conseguir o intuito maior da inserção da informática na escola: mudança, dinamização, envolvimento por parte do aluno na aprendizagem. Entre as vantagens potenciais deste trabalho na escola, está o fato desta:

a) ser 'sinônimo' de status social, visto que seu usuário, geralmente crianças e adolescentes, experimentam a inversão da relação de poder do conhecimento que consideram ser propriedade dos pais e professores, quando estes não dominam a Informática; b) possibilitar resposta imediata, o erro pode produzir resultados interessantes; c) não ter o erro como fracasso e sim, um elemento para exigir reflexão/busca de outro caminho. Além disso, o computador não é um instrumento autônomo, não faz nada sozinho, precisa de comandos para poder funcionar, desenvolvendo o poder de decisão, iniciativa e autonomia; d) Favorece a flexibilidade do pensamento; e) estimula o desenvolvimento do raciocínio lógico, pois diante de uma situação-problema é necessário que o aluno analise os dados apresentados, descubra o que deve ser feito, levante hipóteses, estabeleça estratégias, selecione dados para a solução, busque diferentes caminhos para seguir; f) Possibilita ainda o desenvolvimento do foco de atenção-concentração; g) favorece a expressão emocional, o prazer com o sucesso e é um espaço onde a criança/jovem pode demonstrar suas frustrações, raiva, projeta suas emoções na escolha de produção de textos ou desenhos. (FERREIRA, 2002, p.29)

Outra concepção que influencia a atitude de rejeição é a vergonha dos professores por não saber usar a tecnologia digital nas tarefas simples em seu dia a dia. Alguns não possuem um celular para comunicação e são avessos ao bombardeio das crianças com os recursos digitais. Acreditam que a família já diverte as crianças e que a escola tem de apresentar-lhes um mundo mais concreto e lúdico. Estes docentes sabem utilizar as tradicionais ferramentas 
concretas de ensino para as crianças, lançam mão de estórias e brincadeiras na tentativa de conquistar a atenção das crianças. Quando apresentados à linguagem digital, seus olhos brilham e, do mesmo jeito que os das crianças, entendem que existem possíveis inovações que podem ser inseridas em sua rotina, mas que para isso se faz necessária uma capacitação em que sejam associadas a metodologia tecnológica e as experiências escolares das crianças pequenas.

Considerando as representações sociais positivas, percebe-se que os docentes entendem que a chegada da informática traz benefícios a tarefas básicas da rotina pedagógica. Eles reconhecem que a informática oferece possibilidades além da sala de aula, para interação e múltiplas experiências de aprendizagem. Quando o próprio aluno cria, faz, age, decidindo o que melhor solucionaria seu problema, torna-se um sujeito ativo de sua aprendizagem Os recursos informatizados, ao serem manipulados pelo indivíduo, permitem a construção e a reconstrução do conhecimento, tornando a aprendizagem uma descoberta. Quando a informática é utilizada a serviço da educação emancipadora, o aluno ganha em qualidade de ensino e aprendizagem.

A chegada das tecnologias ao ambiente escolar da educação infantil tem provocado uma ruptura de paradigmas, pois o concreto e o virtual têm agregado experiências lúdicas importantes para a construção do aprendizado das crianças. Os recursos oferecidos pela informática, se bem aproveitados, nos dão suporte para o desenvolvimento de diversas atividades com os alunos, tais como: pesquisas diversas, blogs de atividades lúdicas, passatempos contextualizados com as atividades matemáticas e de letramento. São inúmeras vantagens em que a sala de aula pode ser transposta para uma realidade que cativa e apaixona as crianças pequenas.

No entanto, a escola de educação infantil ainda continua muito arraigada ao padrão jesuítico, no qual o professor fala, o aluno escuta, o professor manda, o aluno obedece. A chegada da era digital coloca a figura do professor como um "mediador" de processos que são, estes, sim, capitaneados pelo próprio sujeito aprendiz. Porém, para que isso ocorra de fato, é preciso que o professor não tenha "medo" da possibilidade de autonomia do aluno. Crenças como a de que o computador substituirá o professor precisam ser deixadas de lado, e isto só é possível por meio da formação para o entendimento de que a informática muda os padrões de ensino, mas também interfere na aprendizagem. Portanto, é importante que o professor entenda que o aluno de hoje bombardeado pela tecnologia, cada dia mais cedo, também tem seu modo de aprender reformulado e influenciado. 
A utilização de recursos informatizados pode juntar elementos da educação formal com outros da educação não formal, beneficiando tanto o aspecto prático dos meios não formais quanto a teoria mais generalizada, presente nos meios acadêmicos. Por intermédio de sites na internet, por exemplo, podem-se trazer para dentro da sala de aula filmes, imagens, desenhos e livros detalhando para as crianças etapas no desenvolvimento de seres vivos, dentre outros.

Mesmo destacando as vantagens da utilização da informática, para que as tecnologias possam concretizar seus objetivos, faz-se necessário, além de uma preparação adequada dos professores, um projeto educacional que articule o trabalho do professor ao uso destas tecnologias. Do contrário, corre-se o risco de se confrontar com velhas práticas, mais caras e com um caráter pretensamente moderno, haja vista que a simples introdução da tecnologia não é capaz de modificar as concepções do professor acerca das questões pedagógicas.

O sucesso do uso da informática como uma possibilidade de inovação educativa, que pode favorecer a expansão da inteligência, depende da forma como ocorre a relação entre o usuário e as informações contidas no programa por ele utilizado. Quanto mais interativa for essa relação, maiores serão as possibilidades de enriquecer as condições de elaboração do saber.

Do ponto de vista de Valente (1999), mudar a visão e desenvolver capacidades para perceber os novos recursos que as tecnologias põem à disposição é mais do que receber treinamento para manusear o computador. $\mathrm{O}$ autor afirma que:

A formação do professor para ser capaz de integrar a Informática nas atividades que realiza em sala de aula deve prover condições para ele construir conhecimento sobre as técnicas computacionais, entender por que e como integrar o computador na sua prática pedagógica e ser capaz de superar barreiras de ordem administrativa e pedagógica. Essa prática possibilita a transição de um sistema fragmentado de ensino para uma abordagem integradora de conteúdo e voltada para a resolução de problemas específicos do interesse de cada aluno. Finalmente, deve-se criar condições para que o professor saiba recontextualizar o aprendizado e as experiências vividas durante a sua formação para a sua realidade de sala de aula, compatibilizando as necessidades de seus alunos e os objetivos pedagógicos que se dispõe a atingir. (VALENTE, 1999, p.39)

Portanto, entende-se que para a aceitação e adoção de práticas pedagógicas que utilizem a informática é necessário rever a formação continuada oferecida para os professores que atuam na educação infantil, dentro do curso do ProInfo, oferecido pelo Núcleo de tecnologia Educacional (NTE). 
Aos professores é preciso que estejam dispostos a aprender a aprender, desenvolver as competências para o pleno domínio pedagógico da linguagem digital. Durante a pesquisa, os docentes demonstraram que gostariam de se atualizar para se sentirem incluídos dentro desta inovação, bem como inserir mudanças em sua rotina pedagógica para que possam motivar as crianças a sistematizarem as experiências que vivem ao chegarem à escola.

Considerando as concepções e atitudes dos professores, percebe-se o surgimento de uma consciência de emergência na apropriação da informática como possibilidade de propiciar experiências lúdicas que possam levar as crianças a desenvolver competências para se tornarem cidadãos do mundo. Os professores interpretam que é possível conseguir resultados positivos, pois há entre eles aqueles que sozinhos têm buscado trazer a informática para sua rotina, seja por apropriação de atividades em blogs, imagens, estórias digitalizadas e projetadas no Datashow ou por meio de outros incentivos tecnológicos. O ponto de coesão é que eles compreendem que a utilização da informática na educação é um processo de modernização, renovação e troca de resultados, mais positivos que negativos.

Aliás, este tema de pesquisa ainda não se esgota, pois, mais do que identificar e investigar as representações de professores, é importante, partindo dessas constatações, conseguir pensar e aplicar, com os docentes, um modelo para a formação continuada na educação infantil. Modelo esse que promova a mudança do paradigma de resistência para o de aceitação. Eis, então, um tema que, em breve, permeará uma futura pesquisa de doutorado. 


\section{REFERÊNCIAS}

ABRIC, J. C. A abordagem estrutural das representações sociais. In: MOREIRA, A. S. P.; OLIVEIRA, D. C. de (org.). Estudos interdisciplinares de representação social. Goiânia: $\mathrm{AB}, 1998$.

AFONSO, C. Professores e Computadores Representações, atitudes e comportamentos. Coleção Horizontes da Didáctica. Edições Asa/ Clube do professor, Portugal, 1993.

AFONSO, M. L.; ABADE, F. L. Para reinventar as rodas: rodas de conversa em direitos humanos. Belo Horizonte: RECIMAM, 2008.

AGÊNCIA BRASIL. Mais de $60 \%$ dos alunos de escola pública tem computador em casa, indica pesquisa. EBC, 23 de maio de 2013. Disponível em: http://agenciabrasil.ebc.com.br/noticia/2013-05-23/mais-de-60-dos-alunos-de- escolapublica-tem-computador-em-casa-indica-pesquisa Acesso em: 05 de dezembro de 2013.

ALEXANDROFF, M. C. Os caminhos paralelos do desenvolvimento do desenho e da escrita. Construção Psicopedagógica. São Paulo, v. 18, n. 17, dez. 2010. Disponível em: http://pepsic.bvsalud.org/scielo.php?script=sci_arttext\&pid=S1415-69542010000200003. Acesso em: em 27 fev. 2015.

ALMEIDA, M. E. B. A informática na Escola - PUC-SP 1998. Disponível em: www.divertire.com.br/educacional/artigos/11.htm. Acesso em 15 mar.2015.

ALMEIDA, M. E. B. Educação e tecnologias no Brasil e em Portugal em três momentos de sua história. Educação, Formação \& Tecnologias; vol.1, n.1, p. 23-36, 2008. Disponível em http://eft.educom.pt. Acesso em 25 mar. 2015.

ALMEIDA, M. E. B. Educational Models Transference among South American countries: are there new emergent models? Paulo Freire's pedagogy proposal and the digital technology insertion in teachers' development. In: $L$ ' enseignement secondaire à l'échelle mondiale: bilans et perspectives, ed. Genebra, Suíça: UNESCO, Université de Genéve, p. 241-252, 2005.

ALMEIDA, M. E. B. Informática e formação de professores. São Paulo: MEC/SEED/ ProInfo, 1999.

ALMEIDA, M. E. B Informática e formação de professores. Brasília: Ministério da Educação, 2000.

ALMEIDA, M. E. B; BARRETO, G. O.; JESUS, V. G. S. de. O currículo da escola do século XXI - a integração das TIC ao currículo: inovação, conhecimento científico e aprendizagem. In: SAMPAIO, F. F.; ELIA, M. da F.. (Orgs.). Projeto um computador por aluno: pesquisas e perspectivas. Rio de Janeiro: NCE/UFRJ, 2012. 270 p. ISBN: 978-85-61815-02-8 Disponível em: http://www.nce.ufrj.br/ginape/livro-prouca/livroPROUCA.pdf Acesso em: 10/05/2015. 
ALTOÉ, A.; PENATTI, M. M. O construtivismo e o construcionismo fundamentando a ação docente em ambiente informatizado. In: ALTOÉ, Anair; COSTA, Maria Luisa Furlan; TERUYA, Tereza Kazuko (org). Educação e novas tecnologias. Formação de Professores EAD, Maringá, PR: EDUEM, nº 16, 2005.

ALTOÉ, A. A gênese da informática na educação em um curso de pedagogia: a ação e mudanças da prática pedagógica. 2001, 303 f. Tese (Doutorado em Supervisão e Currículo) Pontifícia Universidade Católica de São Paulo, São Paulo, 2001.

ALTOÉ, A. Formação de professores para o uso do computador em sala de aula. Teoria e prática da educação: educação e informática /Departamento de Teoria e Prática da Educação, Universidade Estadual de Maringá. Maringá, PR: DTP/UEM, v. 1, n. 1, p. 483493, set. 1998.

ALTOÉ, A. O computador na escola: o facilitador no ambiente logo. 1993. Dissertação (Mestrado em Supervisão e Currículo) - Pontifícia Universidade Católica de São Paulo, São Paulo, 1993.

ALTOÉ, A. O professor em atuação no ambiente informatizado. In: ALTOÉ, A. (Org). Temas de educação contemporânea. Cascavel, PR: EDUNIOESTE, 2008, p. 199-212.

ALTOÉ, A. Programa de Informática Aplicada à Educação. In: EDUCAÇÃO E TECNOLOGIA: MOSTRA DE TRABALHOS, 1. 2002, Maringá, PR. Anais... Maringá: UEM/DTP/DFE, 2002.

ALTOÉ. A. O desenvolvimento da informática aplicada no Brasil. In: ALTOÉ, A.; COSTA, M. L. F.; TERUYA, T. K. (Orgs.). Educação e novas tecnologias. Formação de professores - EAD, Maringá, PR: EDUEM, nº 16, 2005.

ALVES-MAZZOTTI, A. J. Representações sociais: aspectos teóricos e aplicações à educação. Em Aberto, Brasília, DF, ano 14, n.61, p.60-78, jan./mar. 1994.

AMANTE, L. A Integração das Novas Tecnologias no Pré-Escolar: Um Estudo de Caso. 2003. Tese (Doutorado em Ciências da Educação). Lisboa: Universidade Aberta, 2003.

AMANTE, L. As TIC na Escola e no Jardim-de-infância: motivos e factores para a sua integração. Sísifo. Revista de Ciências da Educação, n.3, p. 51-64, 2007b. Disponível em: http://sisifo.fpce.ul.pt. Acesso em: 10/06/ 2014.

AMANTE, L. Infância, Escola e Novas Tecnologias, in: COSTA, F., PERALTA, H., VISEU, S. (Org.). As TIC em Educação em Portugal, Porto Editora: Porto, p. 102-127, 2007a.

ANDRADE, P. F.; LIMA, M. C. M. Projeto EDUCOM. Brasília: MEC/OEA, Brasil. 1993.

ARRUDA, A. Representações Sociais e Movimentos Sociais: Grupos Ecologistas e Ecofeministas do Rio de Janeiro. In: MOREIRA, A. S. P.; OLIVEIRA, D. C. (Orgs). Estudos Interdisciplinares de Representação Social. Goiânia: AB, 1998, p. 71-86.

ASSUNÇÃO, A. da A.; OLIVEIRA, D. A. Intensificação do trabalho e saúde dos professores. Educação \& Sociedade, v. 30, n. 107, p. 349-372, 2009. 
BARBOSA, G. C.; de ALMEIDA FERREIRA, M. M. G.; BORGES, L. M.; SANTOS, A. G. dos. Tecnologias digitais: possibilidades e desafios na educação infantil. In: ESUD 2014 - XI CONGRESSO BRASILEIRO DE ENSINO SUPERIOR A DISTÂNCIA. Anais... Florianópolis: UNIREDE, 2014. Disponível em: http://esud2014.nute.ufsc.br/anaisesud2014/files/pdf/128152.pdf. Acesso em 26/04/2015.

BARDIN, L. Análise de Conteúdo. Lisboa, Portugal; Edições 70, LDA, 2009.

BARRETO, R. Formação de professores, tecnologias e linguagens. São Paulo: Loyola, 2002.

BARROS, S., CAVALCANTE, P. S. Os recursos computacionais e suas possibilidades de aplicação no ensino segundo as abordagens de ensino aprendizagem. Anais do Workshop Internacional Sobre Educação Virtual: Realidade e desafios para o próximo milênio. Fortaleza: UECE, 1999.

BARTOLOMÉ, A. R. Sociedad de la información y cambio educativo. Anais. Challengers 2005: IV Conferência Internacional de Tecnologias de Informação e Comunicação na Educação, Braga, Portugal, 2005. p. 1-17.

BELO HORIZONTE (MG). Secretaria Municipal de Educação. Desafios da Formação Proposições Curriculares - Educação Infantil - Rede Municipal de Educação e Creches Conveniadas com a PBH. Belo Horizonte, MG: SMED, 2009.

BOBSIN, D.; VISENTINI M. S.; RECH, I. Em busca do estado da arte do UTAUT: ampliando as considerações sobre o uso da Tecnologia. RAI - Revista de Administração e Inovação, Universidade de São Paulo, Brasil, v. 6, n. 2, p. 99-118, 2009.

BORGES, H. N. Uma classificação sobre a utilização do computador pela escola. Revista Educação em Debate, ano 21, v. 1, n. 27, p. 135-138, Fortaleza, 1999.

BRASIL, Lei $\mathbf{n}^{\mathbf{0}}$ 12.796, de 4 de abril de 2013, que altera a LDB n. 9394/96, diz que as crianças com 4 anos devem ser matriculadas na Educação Infantil. Ministério da Educação e Cultura. Brasília, 2013.

BRASIL, Ministério da Educação e Cultura. Lei de Diretrizes e Bases da Educação Nacional. Lei no 9394, de 20 de dezembro de 1996. Brasília, DF: MEC, 1996.

BRASIL, Ministério da Educação e do Desporto. Secretaria de Educação Fundamental. Referencial curricular nacional para a educação infantil. Brasília, DF: MEC/SEF, 1998.

BRASIL, Ministério da Educação. Secretaria de Educação Básica. Diretrizes curriculares nacionais para a educação infantil / Secretaria de Educação Básica. - Brasília: MEC, SEB, 2010 .

BRITO, G. S.; BOENO, R. K. S; A inserção de tecnologias na prática docente: fazendo o mesmo de forma diferente. In: IX ANPEDSul - SEMINÁRIO DE PESQUISAS EM EDUCAÇÃo DA REGIÃO SUL, Anais, Caxias do Sul, 2012. 
CARNEIRO, R. Informática na Educação: representações sociais do cotidiano. São Paulo: Cortez, 2002.

CARRAHER, D.W. O Papel do Computador na Aprendizagem. Acesso, v.3, n. 5, p. 19-21, 1992. Disponível em: http://www.iq.ufrgs.br/aeq/aspedago.htm. Acesso em 15/03/2015.

CASTANHO, M. E. L. M. Professores e inovação. In: CATANHO, S.; CASTANHO, M. E. L. M. (Orgs). O que há de novo no ensino superior. Do projeto pedagógico à prática transformadora. Campinas, SP: Papirus, 2000, p.75-92.

CERQUEIRA, T. C. S. (Org). Representações sociais e subjetividade: inter-relações em educação. Brasília: Thesaurus, Uniplan, 2012.

CHAU, P.Y.K.; P.J. Hu. Information Technology Acceptance by Individual Professionals: A Model Comparison Approach. Decision Sciences, nº 32, 2001.

CLEMENTS, D. H.; NASTASI, B. K. Os meios eletrônicos de Comunicação e a Educação de Infância. In: SPODEK, B. (Org.). Manual de Investigação em Educação de Infância. Lisboa: Fundação Calouste Gulbenkian, 2002, p. 561-619.

CRESWELL, J. W. Projeto de pesquisa: métodos qualitativo, quantitativo e misto. 3. ed. Porto Alegre: Artmed/Bookman, 2010.

CUBAN, L. Computers Meet Classrooms: classrooms wins, Teachers College Record, 2001

DANTAS, A. S. A formação inicial do professor para o uso das tecnologias de comunicação e informação. Holos, Ano 21, p.13-25, maio/2005.

D'AVILLA GALLO, S. Informática na educação infantil: tesouro ou ouro de tolo? UNESP, $2002 . \quad$ Disponível em: http://www.anped.org.br/reunioes/25/excedentes25/simoneandreagallot07.rtf. Acesso em: 01/04/2015.

DAVIS, F. D. Perceived usefulness, perceived ease of use and user acepptance of information technology. Mis Quarterly, v. 13, n. 3, p. 319-340, 1989.

DE CARVALHO, Á. A. Reflexões acerca das representações sociais em Durkheim e o estudo sobre a AIDS. CAOS - Revista Eletrônica de Ciências Sociais, n. 18, setembro de 2011.

DISHAW, M. T.; STRONG, D. M. Extending the technology acceptance model with tasktechnology fit constructs. Information and Management, v. 36, p. 9-21, 1999.

DOISE, W. Atitudes e Representações Sociais. In: JODELET, D. (Org) As Representações Sociais, Rio de Janeiro, EdUERJ, p. 187-203, 2001.

DURKHEIM, E. As regras do método sociológico. São Paulo, 2a Ed, Martins Fontes, 2003.

DURKHEIM, E. Conclusão. In: As Formas Elementares de Vida Religiosa. São Paulo. Ed. Paulinas, 1989. 
EGLER. T. T. C.; COSTA. A. S. V. Interação social e tecnologia na escola. In: Projeto um computador por aluno: pesquisas e perspectivas. Rio de Janeiro: NCE/UFRJ, 2012. 270 p. ISBN: 978-85-61815-02-8, 2012.

FERREIRA, A. C. Metacognição e desenvolvimento profissional de professores de matemática: uma experiência de trabalho colaborativo. 2003. Tese (Doutorado). Campinas: FE - Unicamp, 2003.

FIGUEIREDO, A. A. F.; QUEIROZ, T. N. de. A utilização de rodas de conversa como metodologia que possibilita o diálogo. In: SEMINÁRIO INTERNACIONAL FAZENDO GÊNERO 10. Anais Eletrônicos, ISSN 2179-510X Florianópolis, 2012. Disponível em: http://www.fazendogenero.ufsc.br/10/resources/anais/20/1384186533_ARQUIVO_Alessandr aAniceto.pdf Acesso em: 10/05/15.

FINO, C.; SOUSA, J. As TIC Redesenhando as Fronteiras do Currículo. Revista GalegoPortuguesa de Psicologia e Educação, v. 8, n.10, ano 7, p. 2051-2063, 2003.

FIORENTINI, D.; LORENZATO, S. Investigação em educação matemática: percursos teóricos e metodológicos. 2. Ed. Ver. - Campinas, SP: Autores Associados, 2007.

FLORES, A. M. A informática na educação: uma proposta pedagógica. Tubarão, 1996. 86 p. Monografia (Especialização em Informática). Coordenadoria do Curso de Especialização em Informática, 1996.

FORTALEZA (CE). Secretaria de Educação do Estado do Ceará. Orientações Curriculares para a Educação Infantil. Fortaleza, CE: SEDUC, 2011.

FREIRE, P. Pedagogia dos sonhos possíveis. In: Freire, A. M. (Org.). São Paulo: Editora Unesp, 2001.

FREIRE, P. Pedagogia da autonomia - saberes necessários à prática educativa. São Paulo: Paz e Terra, 2003.

FREIRE, P.; SHOR, I. Medo e ousadia. O cotidiano do professor. Rio de Janeiro: Paz e Terra, 1986.

FUGIMOTO, S. M. A. O computador na sala de aula: o professor de educação básica e sua prática pedagógica. 2010. 143 f. Dissertação (Mestrado em Educação). Universidade Estadual de Maringá: Maringá, PR, 2010.

FUGIMOTO, S. M. A; ALTOÉ. A.Computador na Educação e os desafios Educacionais. In: X Congresso Nacional de Educação EDUCERE - Anais - Pontifícia Universidade Católica do Paraná. Anais. Curitiba, PR, 2009.

GALLO, S. A. d'A. Informática na Educação Infantil: Tesouro ou ouro de tolo. REUNIÃO ANUAL DA ANPED, v. 25, 2002.

GIL, A. C. Métodos e Técnicas de Pesquisa Social. 5. ed., São Paulo: Atlas, 2008. 
GOMES, E. M. Uma experiência com o uso da Lousa Digital Interativa por profissionais da educação infantil. ETD: Educaçao Temática Digital, n. 12, p. 268-286, 2011.

GOODHUE, D. L.; THOMPSON, R. L. Task-technology and individual performance. MIS Quarterly, v. 19, n. 2, Jun. 1995, p. 213-236. ISO/IEC DIS 14598-5 Information technology evaluation of software product. Part 5: Process for evaluators. Disponível em: <http://www.cse.dcu.ie/essiscope/sm4/14598-5.html>. Acesso em 23 set. 2013

GREGIO. B M. A. A informática na Educação: As representações sociais e o grande desafio do professor frente ao novo paradigma educacional. In: Revista Digital da CVARicesu,Volume 2, Número 6, Campo Grande, Mato Grosso, 2003.

GUIMARAES, T. M. M. A representação social dos professores das Séries iniciais do ensino fundamental do Município de Cáceres-MT sobre aprender com o uso da tecnologia digital. 2007. Dissertação (Mestrado). Universidade Católica Dom Bosco, Campo Grande - MS, 2007.

GUIMARÃES, D. Relações entre adultos e crianças no berçário de uma creche pública na cidade do Rio de Janeiro: técnicas corporais, responsividade, cuidado. 2008. Tese (doutorado em educação) - Pontifícia Universidade Católica do Rio de Janeiro, 2008.

HAETINGER, M. G. O Universo Criativo da Criança na educação. Coleção Instituto Criar. vol.03. Rio Grande do Sul, 2005.

JAPIASSU, H. Pedagogia da incerteza. Rio de Janeiro: Imago, 1983.

JODELET, D. (Org). As Representações Sociais. Rio de Janeiro: Eduerg, 2001.

JODELET, D. Loucuras e representações sociais. Petrópolis, RJ: Vozes, 2005.

JORNAL DA CIÊNCIA. O uso do computador ainda assusta professores. 09 de maio de 2011. Órgão da Sociedade Brasileira para o progresso da Ciência - SBPC. Disponível em: http://www.jornaldaciencia.org.br/Detalhe.jsp?id=77447 Acesso em 08 de janeiro de 2014.

KENSKI, V. M. Processos de interação e comunicação no ensino mediados pelas tecnologias. In: ROSA, D. E.G; SOUZA, V. C. Didática e prática de ensino - interfaces com diferentes saberes e lugares formativos. Rio de Janeiro: DP\&A, 2002, p.254-264.

KENSKI, V. M. Novas tecnologias, o redimensionamento do espaço e do tempo e os impactos no trabalho docente. 1998. Disponível em: www.ufba.br/prossiga/vani.htm. Acesso em março de 2015.

LEITE, L.S et al (2003). Tecnologia educacional: descubra suas possibilidades na sala de aula. Petrópolis, RJ: Vozes.2003

LEVY, P. Cibercultura. Rio de Janeiro: Editora 34, 1999.

LEVY, P. Conexão Planetária: o mercado, o ciberespaço, a consciência. São Paulo: Editora 34, 2001. 
LÉVY, P. As tecnologias da inteligência: o futuro do pensamento na era da informática. Rio de Janeiro, ed.34, 1993.

LIBÂNEO, J. C. Adeus professor, adeus professora?: novas exigências educacionais e profissão docente. 2. ed. São Paulo: Cortez Editora, 1998. (Coleção Questões da Nossa Época).

LIBANEO, J. C.; OLIVEIRA, J. F. de; TOSCHI M. S.. Educação Escolar: Políticas, estrutura e organização. São Paulo: Cortez, 2003.

LISBOA, P. Informática na educação infantil: uma experiência no CEI Professor Millo Carli Mantovani. $2008 \quad$ In: http://alb.com.br/arquivomorto/edicoes_anteriores/anais17/txtcompletos/sem16/COLE_3462.pdf $\quad$ acesso em 29/04/2015.

LOLLINI, P. Didática e computadores: quando e como a informática na escola. São Paulo: Loyola, 1991.

LÜDKE, M.; ANDRÉ, M. E. D. A. Pesquisa em educação: abordagens qualitativas. São Paulo: EPU, 1986.

MARTINS, J. G. et al. A transformação do ensino através do uso da tecnologia da educação. In: XIX Congresso Nacional da Sociedade Brasileira de Computação, Rio de Janeiro, PUC. Anais, 1999.

MARTÍNEZ, J. H. G. Novas tecnologias e o desafio da educação. In: TEDESCO, Juan Carlos (org). Educação e novas tecnologias: esperança ou incerteza? Trad. de Claudia Berliner, Silvana Cobucci Leite. São Paulo: Cortez; Buenos Aires: Instituto Internacional de Planejamento de la Educacion; Brasília: UNESCO, 2004. p.105.

MATTEI, C. O prazer de aprender com a informática na Educação Infantil. 2011. Disponível em: http://www.educadores.diaadia.pr.gov.br/arquivos /pedagogia_artigos/ainformedinf.pdf. Acesso em 28/04/2015.

MENEZES, S. P. (1993). Logo e a Formação de Professores: o uso interdisciplinar do computador na educação. 1993. Dissertação (Mestrado) ECA/USP, São Paulo., São Paulo, 1993.

MERCADO, L. P. L. Formação continuada de professores e novas tecnologias. Maceió: EDUFAL, 1999.

MINAYO, M. C. S. (Org). Pesquisa Social: teoria, método e criatividade. $2^{\text {a }}$ ed., Petrópolis: Vozes, 1994.

MINAYO, M. C. de S. (org.) Pesquisa social. 21 ed. Petrópolis: Vozes, 2002, 80 p.

MORAES, M. C. Informática educativa no Brasil: uma história vivida, algumas lições aprendidas. Revista Brasileira de Informática na Educação. Florianópolis, n.1, p. 19-44, set, 1997. 
MORAES, M. C. Novas tendências para o uso das tecnologias da informação na educação. In: FAZENDA, Ivani Catarina Arantes et al. Interdisciplinaridade e novas tecnologias: formando professores. Campo Grande, MS: Ed. UFMS, 1999.

MORAN, J. M. Educação inovadora na Sociedade da Informação, Anped, 2005. Disponível em anped.org.br/reuniões/23/textos/moran. Acesso em 23 de dezembro de 2013.

MORAN, J. M. Mudar a forma de ensinar com a internet: transformar a aula em pesquisa e comunicação. In: MEC/SEED - Salto para o Futuro: TV e informática na educação, Série Estudos, 1998.

MORAN, J. M.; MASETTO, M.; BEHRENS, M. A. Novas Tecnologias e Mediação Pedagógica. São Paulo: Papirus, 2000.

MOREIRA, A. Crianças e Tecnologia, Tecnologia e Crianças. In PONTE, J. P. (Org). A formação para a Integração das TIC na Educação Pré-Escolar e no $1^{\circ}$ Ciclo do Ensino Básico. Porto: Porto Editora, p. 09-17, 2002.

MOREIRA, D.A. O Método Fenomenológico na Pesquisa. São Paulo: Pioneira Thomson Learnig, 152p., 2004.

MORRISH, I. Para uma educação em mudança. Lisboa: Livros Horizonte, 1981.

MOSCOVICI, S. A Era das representações sociais. Trad. Maria Helena Fávero, 1986.

MOSCOVICI, S. Representações sociais: investigações em psicologia social. Rio de Janeiro: Vozes, 2003.

MOURA, A. Geração móvel: um ambiente de aprendizagem suportado por tecnologias móveis para a "geração polegar". Universidade do Minho. Centro de Competência, Portugal, 2009.

NASCIMENTO M. A. G. do; SILVA, C. N. M. da. Rodas de conversa e oficinas temáticas: experiências metodológicas de ensino-aprendizagem em geografia. In: Encontro Nacional de Pratica de Ensino em Geografia - 10 ENPEG. Anais... Porto Alegre, 2009.

NASCIMENTO, D M. Metodologia do Trabalho Científico - Teoria e prática. Editora Forense, 2012.

NEVES, C. M. C; MEDEIROS, L. L. Boletim Salto para o Futuro. Debate: Mídias na Educação. MEC/SEED. Brasília, Novembro/Dezembro, 2006. Disponível em: http//www.tvebrasil.com.br/salto Acesso em: 25/03/2015.

NÓVOA, A. Formação contínua de professores: realidades e perspectivas. Aveiro, 1991.

OLIVEIRA, D. A. Os trabalhadores da educação e a construção política da profissão docente no Brasil. Educar em revista, v. 1, 2010.

PAIS, L. C. Educação Escolar e as tecnologias da informática. 1 ed. Belo Horizonte: Autêntica, 2005. 
PAIVA, V. L. M. de O. O Uso da Tecnologia no Ensino de Línguas Estrangeira: breve retrospectiva histórica. Atualização. Belo Horizonte, 2008. Disponível em: <www.veramenezes.com/techist.pdf> acesso em 05 de fevereiro de 2014.

PAPERT, S. Logo: Computadores e Educação. São Paulo: Editora Brasiliense, 1985, tradução.

PAPERT, S.. A máquina das crianças: repensando a escola na era da informática. Tradução de Sandra Costa. Porto Alegre: Artes Médicas, 2008.

PEREIRA, A. R. ; LOPES, R. Legal: Ambiente de Autoria para Educação Infantil apoiada em Meios Eletrônicos Interativos. In: SIMPÓSIO BRASILEIRO DE INFORMÁTICA NA EDUCAÇÃO. Anais... Juiz de Fora, MG, p. 23-30. 2005.

PRENSKY, M. Digital natives, digitsl immigrants. On the horizon, United Kingdom, MCB University Press, v.9, n. 5, 2001.

RIPPER, A. V. "O Computador chega à escola. Para quê?" In: Revista Tecnologia Educacional. São Paulo, 1995, pp. 40-43.

RHEINGOLD, H. Smart Mobs. The next social revolution. Perseus Publishing, 2003.

ROBEY, D. User Attitudes and Management Information System Use. Academy of Management Journal, v.22, n.3, p.527-538. 1979.

ROSA, R. Trabalho docente: dificuldades apontadas pelos professores no uso das tecnologias. Encontro de Pesquisa em Educação, v. 1, n. 1, p. 214-227, 2013.

SAMPAIO, F.F.; ELIA M. F. (Orgs.) Projeto um computador por aluno: pesquisas e perspectivas. Rio de Janeiro: NCE/UFRJ, 2012. 270 p. ISBN: 978-85-61815-02-8, 2012.

SANTOS, G. L. ; BRAGA C. B. Tablets, laptops, computadores e crianças pequenas: novas linguagens, velhas situações na educação infantil. Brasília: Liber Livros, 2012.

SANTOS, G. L. A tecnologia, a ciência e seus modos de produção: representações de professores do ensino fundamental. Linhas Críticas, Brasília, UnB, v. 13, n. 24, p. 21-36, jan./jun. 2007.

SANTOS, G. L. Alguns princípios para situações de engenharia de softwares educativos. Inter-Ação, Goiânia, UFG, v. 34, n. 1, p. 17-36, jan./jun. 2009.

SANTOS, G. L.; ANDRADE, J. B. F de. (Orgs.) Virtualizando a escola: Migrações docentes rumo à sala de aula virtual. Brasília: Editora Liber Livro, 2010.

SANTOS, G. L.; BRAGA, C B. O uso do computador na educação infantil: um estudo de caso no Distrito Federal. Revista Latino Americana de Tecnología Educativa, Extremadura (Espanha), v. 3, n. 3, p. 10-28, 2004. 
SATO, M. Apaixonadamente pesquisadora em Educação Ambiental. Educação, Teoria e Prática, v.9. n.16/17, p. 24-35, 2001.

SCHÕN, D. Formar professores como profissionais reflexivos. In: NÓVOA, A. (Org.) Os professores e sua formação. Lisboa, Dom Quixote, 1992.

SILVA, C. A. Crianças e computadores: um estudo exploratório sobre a informática na educação infantil no Distrito Federal. 2010. Dissertação (mestrado). Universidade de Brasília, Faculdade de Educação. Brasília, DF, 2010.

SILVA, P. M.; DIAS, G. A. Teorias sobre a aceitação de tecnologia: Por que os usuários aceitam ou rejeitam as tecnologias de informação? BJIS, Brazilian Journal of Information Science, n.2, p. 69-91, Jul/Dez, 2007.

SILVA, P. PIMENTEL V. SOARES J. A utilização do computador na educação: aplicando o Technology Acceptance Model (TAM). Revista Biblionline, v. 8, número especial, p. 263 272. João Pessoa, 2012.

STRAUB, D.; KEIL, M.; BRENNAN, W. Testing the technology acceptance model across cultures: a three country study. Information \& Management, v. 33, n.1, p. 1-11, 1997.

TARJA, S. F. Informática na educação: Novas ferramentas pedagógicas para o professor na atualidade. 4.ed. São Paulo: ÉRICA, 2001.

TRIVIÑOS, A. N. S. Introdução à pesquisa em ciências sociais. A Pesquisa Qualitativa em Educação. São Paulo: Atlas. 1987.

VALENTE, J. A (Org.). Formação de professores para o uso da informática na escola. Campinas, SP: UNICAMP/NIED, p. 1-19, 2003.

VALENTE, J. A (Org.). O computador na sociedade do conhecimento. Campinas, SP: UNICAMP/NIED, 1999.

VALENTE, J. A (Org.). O Professor no ambiente logo: formação e atuação. Campinas, SP: UNICAMP/NIED, 1996.

VALENTE, J. A. Computadores e conhecimento: repensando a educação. Campinas, SP: Gráfica Central da UNICAMP, 1993a.

VALENTE, J. A. Diferentes usos do computador na Educação. Em Aberto. Brasília, v.57, n. 12, jan/mar 1993b.

VALENTE, J. A. Liberando a mente: computadores na educação especial. Campinas, SP: Graf. Central da UNICAMP, 1991.

VEEN, W; WRAKKING, B. Educação na era digital. Revista Pátio-Educação Infantil. Porto Alegre, Ano IX, n. 28, p. 4-7, 2011.

VEIGA, I. P. A.; CARDOSO, M. H. F. (Orgs). Escola fundamental: currículo e ensino. Campinas,SP: Papirus, 1991. 
VENKATESH, V. et al. User acceptance of information technology: toward a unified view. MIS Quarterly, Minneapolis, v. 27, n. 3, p. 425-478, Sept. 2003.

VENKATESH, V.; MORRIS, M. G.; DAVIS, G. B.; DAVIS, F. D. User acceptance of information technology: toward a unified view. Mis Quarterly, v. 27, n. 3, set. 2003.

YIN, R.K. Estudo de caso: planejamento e métodos. 3. ed. Porto Alegre: Bookman, 2005. 
APÊNDICE

APÊNDICE A - QUESTIONÁRIO

\section{Identificação:}

Questão 1 - Idade:

( ) Entre 20 e 25 anos

( ) Entre 25 a 30 anos

( ) Entre 31 a 35 anos

( ) Entre 36 a 40 anos

( ) Entre 40 a 45 anos

( ) Acima de 45 anos

Questão 2-Gênero

( ) Masculino

( ) Feminino

\section{Formação Docente e Experiência}

Questão 3 - Formação Acadêmica

( ) Licenciatura em:

Ano de Conclusão

( ) Especialização em

Ano de Conclusão

Questão 4 - Experiência em Docência

a) Total de anos de Atuação

( ) entre 1 a 3 anos

( ) entre 4 a 6 anos

( ) entre 7 a 10 anos

( ) acima de 10 anos

b) Tempo de Atuação na educação Infantil

( ) entre 1 a 3 anos

( ) entre 4 a 6 anos

( ) entre 7 a 10 anos

( ) acima de 10 anos

\section{O uso de Recursos Informatizados}


Questão 05 - Considerando o uso e acesso a recursos informatizados, responda :

a) O que normalmente acessa em casa ?

b) O que normalmente acessa na escola ?

Questão 06 - Qual a tecnologia que utiliza para o acesso:

( ) Computador de mesa

( ) Smartphone/ Celular

( ) Tablet

( ) Notebook

Questão 07 - Normalmente quanto tempo fica conectado no espaço de um dia

( ) até 1 hora

( ) entre 1 e 2 horas

( ) entre 3 e 4 horas

( ) acima de 5 horas

\section{Pressupostos sobre a inserção da informática na educação}

Questão 08 - Considerando que você atua com crianças pequenas, gostaria que assinalasse, entre as afirmativas abaixo, qual(is) justifica(m) a inserção de recursos tecnológicos na educação Infantil:

( ) Hipótese de ordem social - a informática vai dominar o mundo, então todos devem saber utiliza-la.a escola precisa conhecer como funciona e integrar a suas pratica o quanto antes;

( ) Hipótese de ordem vocacional - A informática na escola pode contribuir para preparar os alunos para postos de trabalho bem remunerados;

( ) Hipótese de ordem pedagógica - Estes encaram a informática como fomentadora de uma nova possibilidade de aprendizado, pensamento e crescimento emocional e cognitivo;

( ) Hipótese catalítica - As escolas podem ser mudadas ou modificadas; podem incorporar novos meios de aprendizagem que facilitem a vida do professor e do aluno.

\section{Concepções sobre recursos informatizados}

Questão 09 - Assinale a (s) afirmação(oes) que mais interpreta(m), em sua concepção, o que seria o uso da tecnologia na escola:

( ) Como máquina de ensinar, a tecnologia com substituta do professor; 
( ) Como objeto de estudo, a própria tecnologia é estudada em suas variáveis, sua história, implicações seu impacto social e efeitos.

( ) Como recurso facilitador de tarefas, para processar textos, facilitar cálculos matemáticos, elaborar e selecionar dados, desenhar utilizar simulações

( ) Como "máquina ensinável" - Privilegia a utilização deste como uma ferramenta programável, capaz de desenvolver capacidades cognitivas do aluno, através do controle que exerce sobre a máquina, ensinando-o.

( ) Computador como "meio para simulações e jogos": momento em que o aluno faz uma atividade de simulação no computador e os jogos servem mais como entretenimento, ambos estimulam o desenvolvimento do raciocínio sofisticado e a habilidade de soluções do problema;

( )Computador como "meio de aprendizagem por descobertas": O usuário desenvolve um trabalho interativo com o computador, no qual o erro é o ponto de partida para reflexão, análise e busca de novas alternativas de resolução, valorizando assim a construção do conhecimento por meio da exploração, da busca e da investigação; 


\section{APÊNDICE B - ROTEIRO DA ENTREVISTA}

$\checkmark$ Apresentação dos objetivos da pesquisa

$\checkmark$ Começe falando sobre o uso que você faz da tecnologia no dia a dia e na escola.

$\checkmark$ Fale em poucas palavras como você interpreta a implantação do Laboratório de informática? Sente-se preparado? Fez algum curso?

$\checkmark$ Fale como você usa a Tecnologia em sua sala e por quê.

$\checkmark$ Pensando até agora nossa conversa, o que em sua opinião falta para que os recursos tecnológicos sejam mais bem aproveitados na escola? 


\section{APÊNDICE C - ROTEIRO DA RODA DE CONVERSA}

Associe imagens ao que representa o uso da informática com os alunos em sua sala de aula ( Divisão em imagens positivas e negativas)

Associe uma ou mais palavras ao que representa o uso da informática com os alunos em sua sala de aula ( Divisão em imagens positivas e negativas) 


\section{APÊNDICE D - IMAGENS USADAS NA RODA DE CONVERSA}

Figura 14 - Computadores na escola

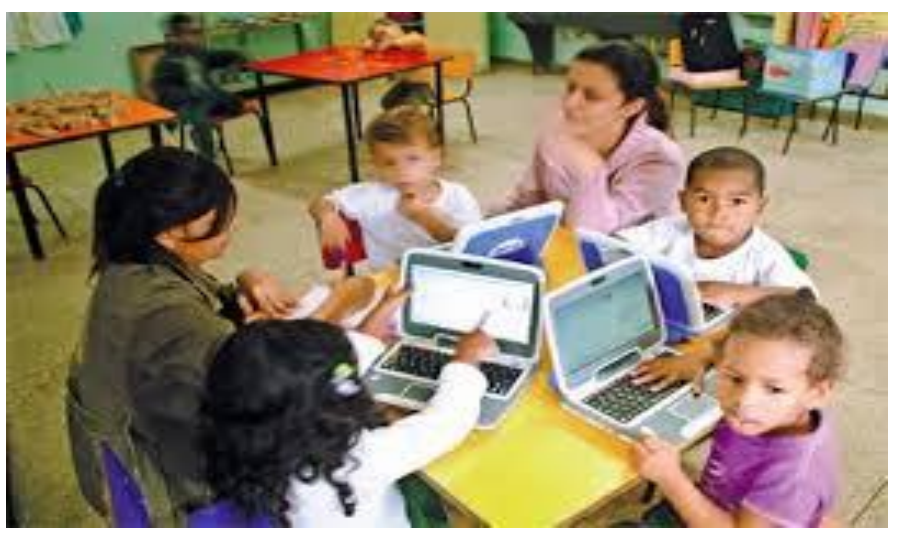

http://revistaescola.abril.com.br/computadores-pre-escola-

Figura 15 - Tecnologia Educacional

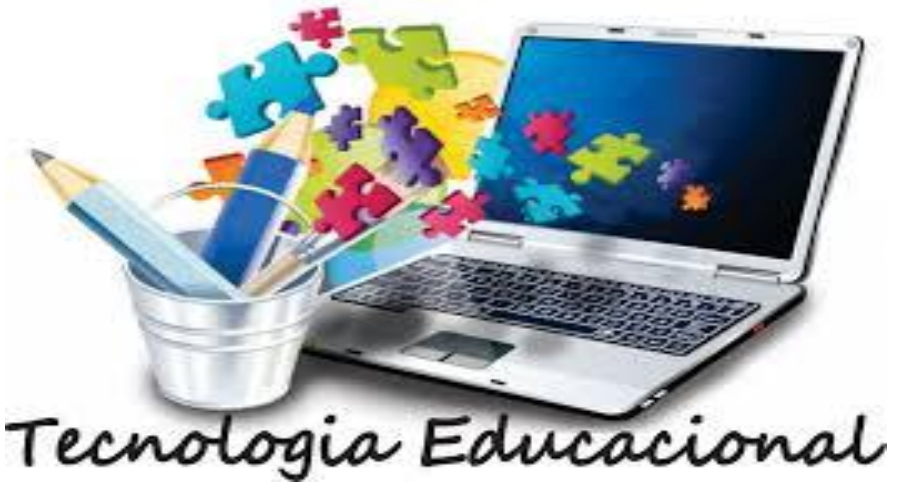

https://infopt-br.examtime.com/tecnologia-educacional-estude-online

Figura 16 - Computador e Crianças

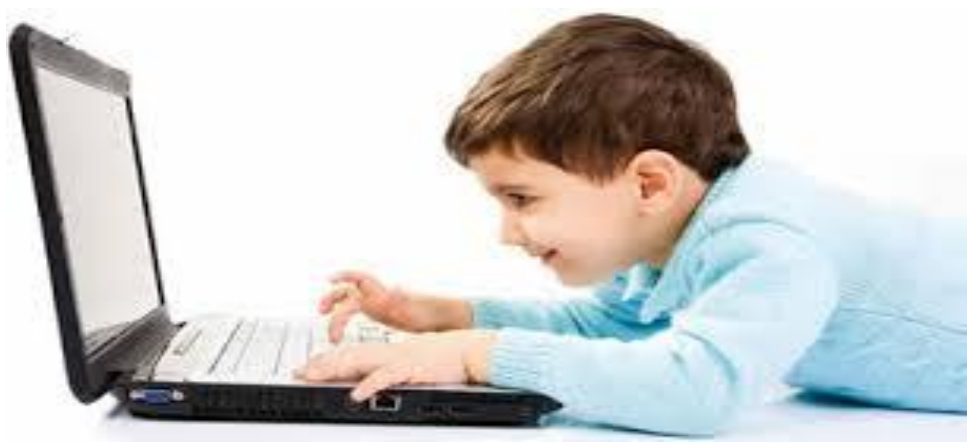

http://www.oglobo.globo.com/google-o-queridinho-das-criancas 
Figura 17 - Professores e computadores

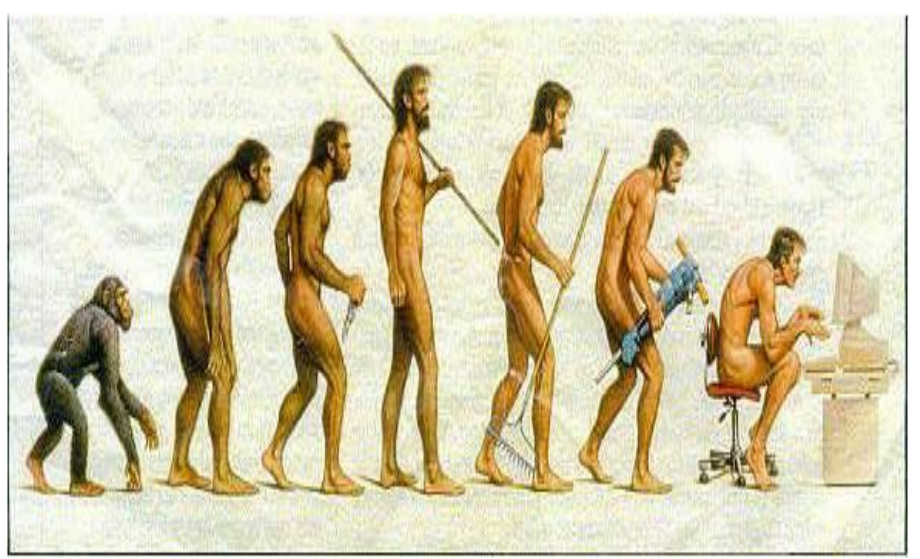

https://www.saladeproframon.blogspot.com

Figura 18 - Impacto das Tecnologias no dia a dia

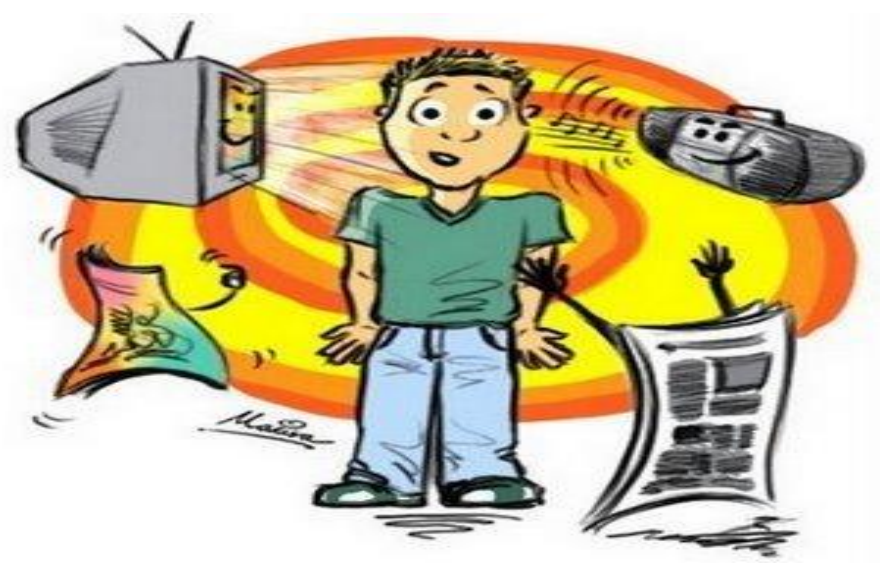

https://www.profraulcuore.blogspot.com

Figura 19 - Recursos Tecnológicos no ensino

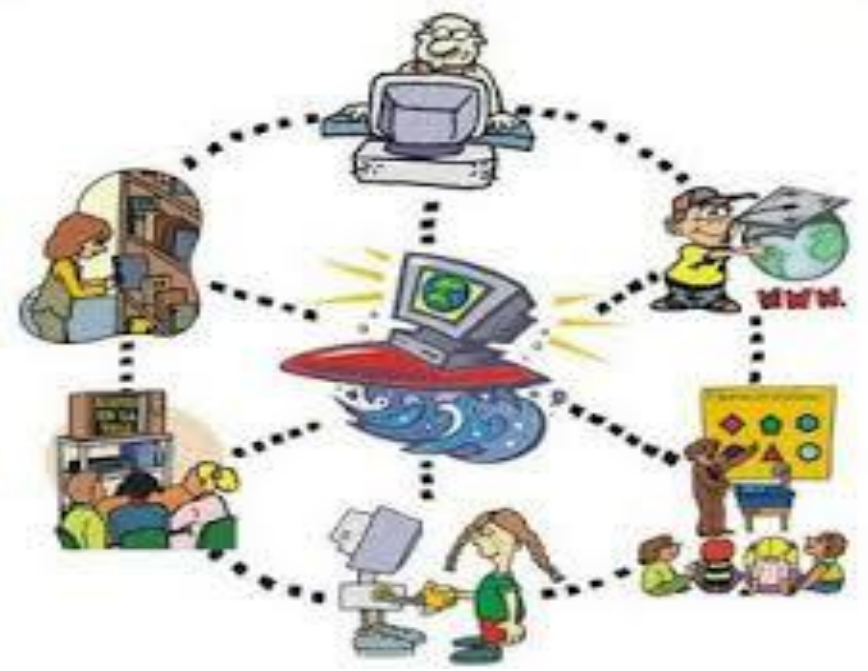

http://www.recursostecnologicosnoensino.blogspot.com 
Figura 20 - Microkids e educação

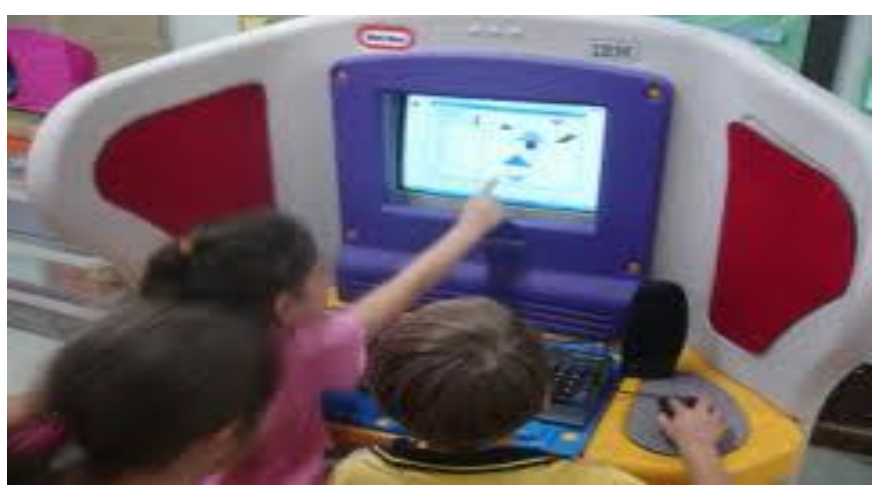

https://www.blog.voluntariosonline.org.br/projeto-social-da-ibm-visa-criancas-da-pre-escola

Figura 21 - Dificuldade Tecnológica

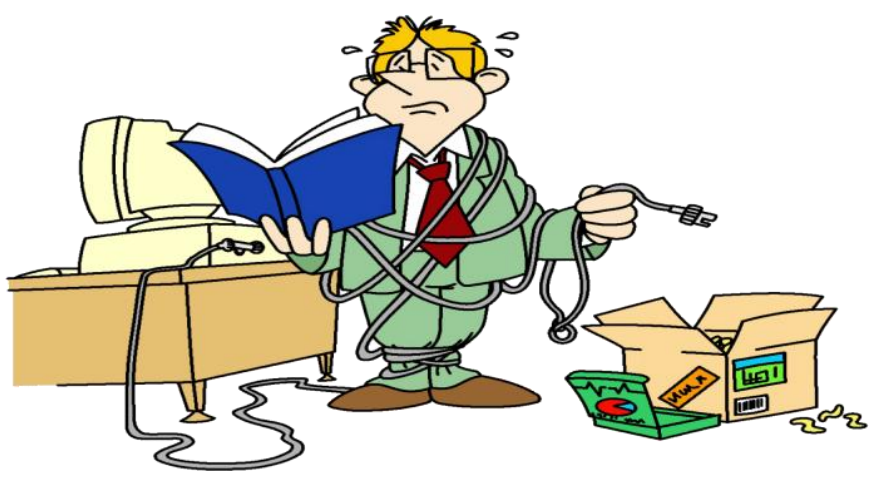

http://www.1papacaio.com.br

Figura 22 - Computador na escola

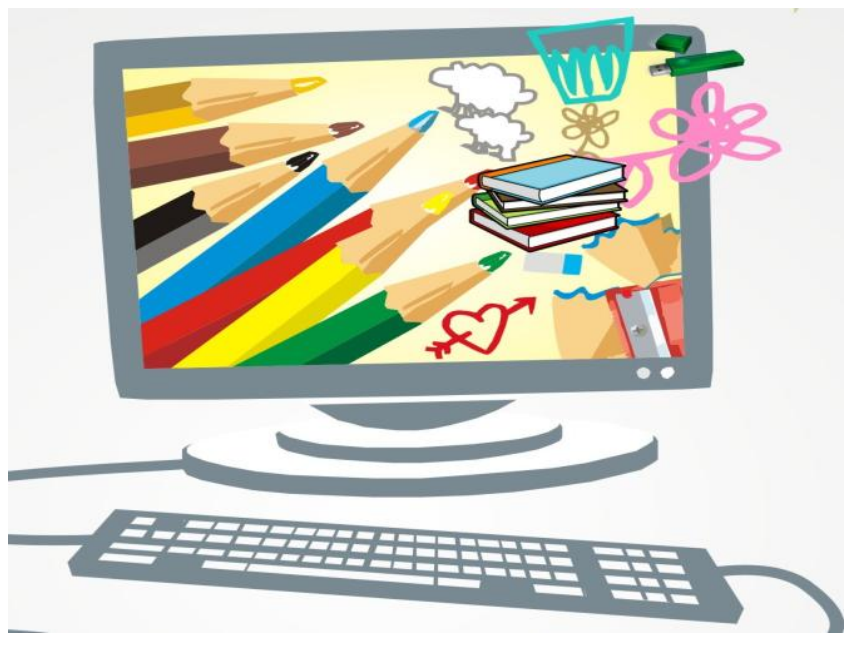

https://www.webquestfacil.com.br 